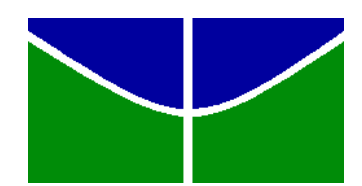

UNIVERSIDADE DE BRASÍLIA

PROGRAMA DE PÓS-GRADUAÇÃO EM CIÊNCIAS DA SAÚDE

FLAVIA ZATTAR PIAZERA

ANÁLISE DE EXPRESSÃO DE GENES DA FAMÍLIA SETD EM

LEUCEMIA LINFOCÍTICA CRÔNICA.

BRASILIA 
FLAVIA ZATTAR PIAZERA

\section{ANÁLISE DE EXPRESSÃO DE GENES DA FAMÍLIA SETD EM LEUCEMIA LINFOCÍTICA CRÔNICA.}

Dissertação apresentada ao Programa de Pós Graduação em Ciências da Saúde da Universidade de Brasília, como parte dos requisitos necessários para obtenção do título de Mestre em Ciências da Saúde.

Orientador: Prof.Fábio Pittella Silva

Co-orientador: Felipe Saldanha de Araújo

BRASILIA 


\section{FLAVIA ZATTAR PIAZERA \\ ANÁLISE DE EXPRESSÃO DE GENES DA FAMÍLIA SETD EM LEUCEMIA LINFOCÍTICA CRÔNICA.}

Dissertação apresentada ao Programa de Pós Graduação em Ciências da Saúde da Universidade de Brasília, como parte dos requisitos necessários para obtenção do título de Mestre em Ciências da Saúde.

Aprovado em --- de ---- de 2015.

BANCA EXAMINADORA

Prof. Dr. Fábio Pittella Silva (Presidente)

Prof. Dr. Diego Oliveira Madureira (membro interno do programa)

Prof. Dra. Rosângela Vieira de Andrade (membro externo)

Prof. Dr. Rodrigo Haddad (membro externo) 
Ao meu pai Flávio Piazera (in memorian), que me encaminhou no universo do profissionalismo, da educação, da honestidade, onde o sucesso é uma consequência do trabalho, da dedição e do vencimento de barreiras. 


\section{AGRADECIMENTOS}

Agradeço à Universidade de Brasilia e ao Programa de Pós-Graduação em Ciências da Sáude, pela oportunidade.

Ao Prof. Fábio Pittella Silva pela confiança, paciência, orientação e ensinamentos, não esquecendo das cobranças, pois essas fazem parte desta historia.

A prof. Andrea Barreto Motoyama e a Dra. Doralina do Amaral Rabello, vocês foram fundamentais para que este sonho pudesse ser realizado.

Aos colegas do laboratório de Patologia Molecular do Cancer (PMC): Rubens e Martha Estrela, por me auxiliarem em tudo o que precisei e nos imprevistos.

Um agradecimento especial ao Prof. Felipe Saldanha Araujo que inúmeras vezes me socorreu, guiou e corrigiu as minhas dúvidas e resultados, espero que futuros trabalhos e pesquisas possam fazer parte dessa parceria.

À minha família: mãe, Camilla, Leonardo por se acostumarem com as minhas ausências para me dedicar a este sonho.

Ao meu pai (in memoriam 2014) que não pode presenciar esta conquista finalizada e para quem eu dedico esta tese de mestrado. Espero seguir seus passos na vida acadêmica.

Ao meu marido e ao pequeno Daniel que sofreram com as minhas ausências desde o segundo mês de gestação para conseguirmos este sonho.

Aos portadores de neoplasias hematológicas, que lutam diariamente e esperam que nossos estudos possam trazer uma chance de cura ou de alivio ao sofrimento. 


\section{RESUMO}

A Leucemia Linfocítica Crônica (LLC) é a neoplasia linfoide crônica mais comum na população ocidental. Assim, várias pesquisas têm sido desenvolvidas para elucidação dos fatores genéticos envolvidos na biologia e progressão da LLC. Alterações epigenéticas têm se mostrado cada vez mais relevantes na gênese de vários tumores e em especial nas neoplasias linfóides agudas e crônicas, e tem como características básicas não causar modificações na sequência do DNA. A metilação de histonas é um dos principais e mais estudados eventos epigenéticos. A família SETD é composta por 10 genes que codificam proteínas com domínio SET. Este domínio está envolvido na metilação de resíduos de lisina em histonas e proteínas não histonas. Até o momento, desconhece-se a relação de genes da família SETD com a leucemogênese da LLC. No presente estudo, foi realizada a avaliação de expressão relativa dos genes da família SETD em 59 amostras de sangue periférico de pacientes portadores de LLC e 10 controles normais através da técnica de PCR em tempo real. O perfil de expressão comparativa dessa família de genes foi correlacionado com as informações clínicas, citogenéticas, imunofenotípicas e hematológicas de maior relevância prognóstica dos pacientes. Notamos que a hipoexpressão do geneSETD1Aapresentase correlacionado com instabilidade cromossômica. O gene SETD2 apresentou elevada contagem de leucócitos no grupo de alta expressão, inferindo elevada massa tumoral. A superexpressão do gene SETD5 define um marcador de progressão da doença devido a elevada contagem de leucócitos nos pacientes do grupo de baixa expressão associado a anormalidades citogenéticas. O gene SETD6 apresentou hipoexpressão nos portadores de LLC em relação aos controles. O gene SETMAR apresentou-se hiperexpresso nos portadores de LLC em relação aos controles. Entretanto, no grupo de pacientes com baixa expressão a contagem leucocitária mostrou-se elevada estando associado a predominância de anormalidades citogenéticas e baixa contagem plaquetária. Sugerimos que nos portadores de LLC, a hipoexpressão do gene SETMAR esteja associada com instabilidade cromossômica e progressão da massa tumoral (aumento da leucocitose). Concluímos que os genes da família SETD possam futuramente ser considerados marcadores evolutivos da LLC.

Palavras chaves: expressão gênica; LLC; família SETD. 


\begin{abstract}
The Chronic lymphocytic leukemia (CLL) is the most common chronic lymphoid malignancy in the western population. Thus, several studies have been developed to elucidate the genetic factors involved in biology and progression of CLL. Epigenetic changes have been shown to be increasingly important in the genesis of various tumors and especially in acute and chronic lymphoid malignancies, and its basic features do not cause changes in the DNA sequence. The histone methylation is one of the leading and most studied epigenetic events. The SETD family consists of 10 genes encoding proteins with SET domain. This domain is involved in methylation of lysine residues on histones and non-histone proteins. So far, unknown whether the genes ratio SETD family with the leukemogenesis LLC. In the present study, we evaluatedthe expression of all SETD family genes in peripheral blood from 59 CLL patients and 10 healthy donors by real time PCR. The expression profile of this gene family was correlated with the most relevant clinical, cytogenetic, immunophenotypic and hematologic prognostic factors of CLL patients. We note that hipoexpressionofSETD1A gene correlated with chromosomal instability. SETD2 gene expression was associated with a high white blood cell count in a dicotomized group of patients with high expression this gene, implying high tumor mass formation when SETD2 is over-expressed. In addition, overexpression of the gene SETD5 sets a marker of disease progression due to higher leukocyte count in patients in the low expression group associated with cytogenetic abnormalities. In the other hand, gene SETD6 was significantely downregulated in patients with CLL compared to controls. Finally, SETMAR gene was found to be upregulated in patients with CLL compared to controls. However, in patients with low expression of SETMAR, we found an increase in leukocyte count as well as in the predominance of cytogenetic abnormalities and low platelet count. We suggest that in patients with CLL, the low expression of SETMAR is associated with chromosomal instability and progression of the tumor mass (increased leukocytosis). We conclude that SETD family genes can be considered future evolutionary markers for CLL.
\end{abstract}

Keys words: SETD family; CLL; expression profile. 


\section{LISTA DE FIGURAS}

Figura 1 Esfregaço de sangue periférico de Leucemia Linfocítica Crônica............27

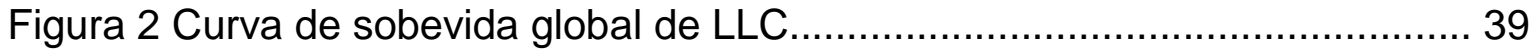

Figura 3 Modelo estrutura esquemático do nucleossomo ................................... 45

Figura 4 Desregulação de genes supressores tumorais por HMTase.................. 48

Figura 5 Diversidade de estados químicos obtidos pela metilação das lisinas..... 49

Figura 6 Metilação de genes com influencia prognóstica na LLC...........................54

Figura 7 Fatores epigenéticos de metilação do DNA em LLC...............................55

Figura 8 Anormalidades epigenéticas na diferenciação de células B................... 56

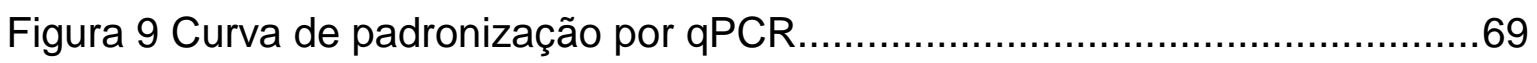

Figura 10 Mediana dos $\Delta \Delta$ Cq dos genes da família SETD em LLC.................... 71

Figura 11 Expressão relativa de SETD1A em amostras de controle versusLLC. 75

Figura 12 Expressão relativa de SETD1A em LLC e contagem leucocitária........ 76

Figura 13. Expressão relativa de SETD1A e contagem plaquetária..................... 76

Figura 14 Expressão relativa de SETD1A e expressão de ZAP-70...................... 77

Figura 15 Expressão relativa de SETD1A e anormalidades citogenéticas........... 77

Figura 16 Expressão relativa de SETD1A e estadiamento de BINET ....................77

Figura 17 Expressão relativa de SETD1B em controles versus LLC.................... 79

Figura 18 Expressão relativa de SETD1B em LLC e contagem leucocitária....... 80

Figura 19 Expressão relativa de SETD1B e contagem plaquetária...................... 80

Figura 20 Expressão relativa de SETD1B e expressão de ZAP-70..................... 81

Figura 21 Expressão relativa de SETD1B e anormalidades citogenéticas............ 81 
Figura 22 Expressão relativa de SETD1B e estadiamento de BINET

Figura 23 Expressão relativa de SETD2 em amostras de controles versus LLC.. 83

Figura 24 Expressão relativa de SETD2 em LLC e contagem leucocitária............83

Figura 25 Expressão relativa de SETD2 e contagem plaquetária..........................84

Figura 26 Expressão relativa de SETD2 e expressão de ZAP-70.........................84

Figura 27 Expressão relativa de SETD2 e anormalidades citogenéticas..............85

Figura 28 Expressão relativa de SETD2 e estadiamento de BINET................... 85

Figura 29 Expressão relativa de SETD3 em amostras de controle e de LLC....... 86

Figura 30 Expressão relativa de SETD3 em LLC e contagem leucocitária............87

Figura 31 Expressão relativa de SETD3 e contagem plaquetária..........................87

Figura 32 Expressão relativa de SETD3 e expressão de ZAP-70........................88

Figura 33 Expressão relativa de SETD3 e estadiamento de BINET.................... 88

Figura 34 Expressão relativa de SETD3 e anormalidades citogenéticas...............89

Figura 35 Expressão relativa de SETD4 em amostras de controle e de LLC........90

Figura 36 Expressão relativa de SETD4emLLC e contagem leucocitária........... 90

Figura 37 Expressão relativa de SETD4e contagem plaquetária......................... 91

Figura 38 Expressão relativa de SETD4e expressão de ZAP-70........................ 91

Figura 39 Expressão relativa de SETD4 e anormalidades citogenéticas..............92

Figura 40 Expressão relativa de SETD4 e estadiamento de BINET ..................... 92

Figura 41 Expressão relativa de SETD5em amostras de controle e de LLC....... 93

Figura 42 Expressão relativa de SETD5emLLC e contagem leucocitária........... 94

Figura 43 Expressão relativa de SETD5 e contagem plaquetária..........................94

Figura 44 Expressão relativa de SETD5e expressão de ZAP-70........................ 95 
Figura 45 Expressão relativa de SETD5e anormalidades citogenéticas

Figura 46 Expressão relativa de SETD5 e estadiamento clínico de BINET ...........96

Figura 47 Correlação entre expressão gene SETD5 e SETD3 .............................96

Figura 48 Expressão relativa de SETD6em amostras de controle e de LLC....... 97

Figura 49 Expressão relativa de SETD6emLLCe contagem leucocitária........... 98

Figura 50 Expressão relativa de SETD6 e contagem plaquetária........................98

Figura 51 Expressão relativa de SETD6e expressão de ZAP-70........................ 99

Figura 52 Expressão relativa de SETD6 e anormalidades citogenéticas..............99

Figura 53 Expressão relativa de SETD6e estadiamento BINET ......................... 100

Figura 54 Expressão relativa de SETD7em amostras de controle e de LLC....... 101

Figura 55. Expressão relativa de SETD7emLLC e contagem leucocitária.......... 102

Figura 56. Expressão relativa de SETD7 e contagem plaquetária.......................102

Figura 57 Expressão relativa de SETD7e expressão de ZAP-70 ....................... 103

Figura 58 Expressão relativa de SETD7 e estadiamento de BINET.................... 103

Figura 59 Expressão relativa de SETD7e anormalidades citogenéticas............. 104

Figura 60 Expressão relativa de SETD8em amostras de controle e de LLC....... 105

Figura 61 Expressão relativa de SETD8em LLC e contagem leucocitária............ 106

Figura 62 Expressão relativa de SETD8e contagem plaquetária........................ 106

Figura 63 Expressão relativa de SETD8e expressão de ZAP-70 ....................... 107

Figura 64 Expressão relativa de SETD8e estadiamento de BINET................... 107

Figura 65 Expressão relativa de SETD8e anormalidades citogenéticas.............. 107

Figura 66 Expressão relativa de SETMARem controle versus LLC.................... 109

Figura 67 Expressão relativa de SETMARem LLC e contagem leucocitária....... 109 
Figura 68 Expressão relativa de SETMAR e contagem plaquetária..................... 110

Figura 69 Expressão relativa de SETMARe expressão de ZAP-70.................... 110

Figura 70 Expressão relativa de SETMAR e anormalidades citogenéticas.......... 111

Figura 71Expressão relativa de SETMAR e estadiamento de BINET .................. 111 


\section{LISTA DE TABELAS}

Tabela 1. Critérios para diagnóstico de LLC................................................... 28

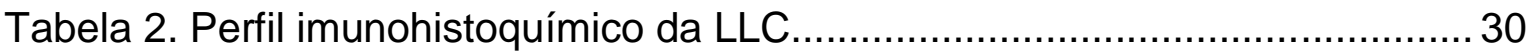

Tabela 3. Sistema de estádio clinico proposto por Rai........................................31

Tabela 4. Sistema de estádio clinico proposto por Binet .....................................32

Tabela 5. Marcadores de agressividade da LLC em relação ao prognóstico.........33

Tabela 6. Principais fatores prognósticos laboratoriais da LLC............................37

Tabela 7. Sistema de avaliação prognóstica e molecular na LLC..........................38

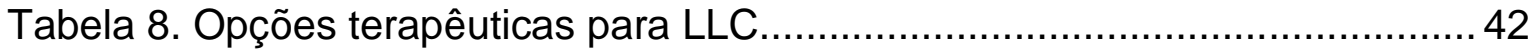

Tabela 9. Modificações pós traducionais das caudas das histonas.......................46

Tabela 10. Sonda padronizadas utilizadas neste ensaio.................................... 68

Tabela 11. Características clínicas e laboratoriais dos pacientes com LLC...........74 


\section{LISTA DE ABREVIATURAS E SIGLAS}

$\mu \mathrm{L}$

Microlitro

$\mu \mathrm{M}$

Micro Molar

AKT

Proteína quinase B

ATM

Via envolvida na diferenciação celular

AZ-H2AZ

Monometilação da lisina 7 em histona $\mathrm{H} 2 \mathrm{~A}$ variante

BCR

Receptor de células B

BIRC3

Baculoviral IAP Repeat Containing 3

BN

Células B naive

BTK

Tirosino quinase de Bruton

CB

Centroblastos

CD

Anticorpo marcado pela citometria de fluxo

$C D H 1$

Cadherin 1

CDKN2A

Cyclin-Dependent Kinase Inhibitor $2 A$

CDKN2B

Cyclin-Dependent Kinase Inhibitor $2 A$

cDNA

DNA complementar

$\mathrm{CH} 3$

Metil

$\mathrm{cm}$

Centímetro

CLLD6

Chronic lymphocytic leukemia deletion region gene 6 protein

CLLD7 Chronic lymphocytic leukemia deletion region gene 7 protein

CLLD8

Chronic lymphocytic leukemia deletion region gene 8 protein

CMSP

Células mononucleares de sangue periférico

COMPASS

Complex Proteins Associated with Set1 
CpG Dinucleotídeo formado por uma citosina unida à uma guanina

$\mathrm{Cq}$

Cycle treshold

DAPK1

Death-Associated Protein Kinase 1

Del Deleção de braço cromossômico

$D K K 1$

WNT signaling pathway inhibitor 1

$D K K 2$

WNT signaling pathway inhibitor 2

$D K K 3$

WNT signaling pathway inhibitor 3

DLPCB

Doença linfoproliferativa crônica de células B

DMRS

Regiõesmetiladas diferencialmente

DNA

Desoxiribonuclease

DNAse I

Desoxiribonuclease I

DNMT1

DNA metiltransferase 1

DNMT3

DNA metiltransferase 3

DNMT3a

DNA metiltransferase $3 \mathrm{~A}$

DNMT3b

DNA metiltransferase $3 B$

DOT1L

Metiltransferase histona H3K79 tipo DOT1L

Dvl

Proteínas Disheveld

DZNep

Metilação de histona 3 deazaneplanocin A

EDTA

Ácido etilenodiamino tetra acético

EHMT1

Euchromatic histone-lysine N-methyltransferase 1a

ERK

Extracelular signal regulated kinases

$E Z H 2$

Catalytic subunit of the Polycomb repressive complex 2

$\mathrm{FISH}$

Técnica de hibridização in situ 


\begin{tabular}{|c|c|}
\hline FCR & Rituximab, ciclofosfamida e fludarabina \\
\hline FCS & Faculdade de Ciências da Saúde \\
\hline GLP & Euchromatic Histone lysine N-methyltransferase \\
\hline $\mathrm{H}$ & Histidinas \\
\hline $\mathrm{H} 1$ & Histona $\mathrm{H} 1$ \\
\hline $\mathrm{H} 2 \mathrm{~A}$ & Histona H2A \\
\hline $\mathrm{H} 2 \mathrm{~B}$ & Histona H2B \\
\hline H3 & Histona $\mathrm{H} 3$ \\
\hline H3k4 & Metilação da lisina 4 histona 3 \\
\hline H3K4me3 & Trimetilação da lisina 4 histona 3 \\
\hline H3К9 & Metilação da lisina 9 histona 3 \\
\hline H3K24 & Metilação da lisina 24 histona 3 \\
\hline H3K36 & Metilação da lisina 36 histona 3 \\
\hline H3К39 & Metilação da lisina 39 histona 3 \\
\hline $\mathrm{H} 4$ & Histona H4 \\
\hline H4K20 & Metilação da lisina 20 histona 4 \\
\hline H4K20me1 & Monometilação da lisina 20 da histona H4 \\
\hline HAT & Acetiltransferase histona \\
\hline HDAC & Deacetilase de histona \\
\hline HDAC1 & Histone deacetylase 1 \\
\hline HDAC2 & Histone deacetylase 2 \\
\hline HDAC3 & Histone deacetylase 3 \\
\hline HDM & Histona demetilase \\
\hline
\end{tabular}




\begin{tabular}{ll} 
HMTase & Metiltransferase de histona \\
HP1 & Metiltransferase histona de H3K9 \\
K & Inhibitor of DNA Binding4 \\
KMT & Lisinas \\
HOX & Metiltransferase lisina de histonas \\
LLA & Genes homeóticos \\
LLC & Leucemia linfoblástica aguda \\
LMA & Leucemia linfocítica crônica \\
LMC & Leucemia mieloide aguda \\
LNH & Leucemia mieloide cronica \\
LYN & Linfoma não Hodgkin \\
mAb & Proteína quinase de interleucina 1 \\
MDM1 & Anticorpo monoclonal \\
MDM-2 & Inativador do gene p53 \\
Me1 & Inativador do gene p53 via 2 \\
Me2 & Monometilação \\
\hline Dimetilação
\end{tabular}

Me2A Dimetilação assimétrica

Me2s Dimetilação simétrica

Me3 Trimetilação

MeCP2 Methyl CpG binding protein 2

MLH1 Homologo 1 de mutL

MLL Gene de leucemia de linhagem mista 
Proto-oncogene, thrombopoietin receptor

mRNA

RNA mensageiro

miRNA

MicroRNA

$\operatorname{miR}-15$

miR-15 microRNA precursor family

$\operatorname{miR}-16-1$

miR-16 microRNA precursor family

MYPT1

Protein phsphatase 1 , regulatory subunit $12^{\underline{a}}$

$\mathrm{NF}-\mathrm{Kb}$

Fator nuclear kappa B

NK

Célula natural killer

NOTCH1

Gene envolvido na diferenciação de células B

NVHIg

Imunoglobulina de cadeia pesada não mutada

NSD1

Nuclear receptor binding SET domain protein 1

NSD2

Wolf hirschhorn syndrome candidate 1

NSD3

Wolf hirschhorn syndrome candidate 1 like 1

NUP98

Nucleoporin $98 \mathrm{kDa}$

P53

Tumor protein 53

PAX5

Paired box (PAX) family

PCR

Reação em cadeia da polimerase

PCNA

Antígeno de proliferação celular nuclear

PI3K

Enzima fosfatidilinositol-3-quinase

PGR

Proteína de resistência

PRMT

Metiltransferase de arginina

PTK

Proteína tirosino quinase

qPCR

PCR em tempo real 


\begin{tabular}{|c|c|}
\hline QR & Quantificação relativa \\
\hline $\mathrm{R}$ & Argininas \\
\hline RAG1-2 & Recombination activating gene 1 \\
\hline RASSF1A & Ras association domain-containing protein 1 \\
\hline RB1 & Retinoblastoma 1 \\
\hline RelA & V-rel avian reticuloendotheliosis viral oncogene homolog $A$ \\
\hline RNA & Ribonuclease \\
\hline RNAse & Ribonuclease \\
\hline Rpm & Rotação por minuto \\
\hline SAM & S-adenosilmetionina \\
\hline SETD1A & SET domain containing 1 a \\
\hline SETD1B & SET domain containing \\
\hline SETD2 & SET DOMAIN CONTAINING 2 \\
\hline SETD3 & SET DOMAIN CONTAINING 3 \\
\hline SETD4 & SET DOMAIN CONTAINING 4 \\
\hline SETD5 & SET DOMAIN CONTAINING 5 \\
\hline SETD6 & SET DOMAIN CONTAINING 6 \\
\hline SETD7 & SET DOMAIN CONTAINING 7 \\
\hline SETD8 & SET DOMAIN CONTAINIG (LYSINE METHYLTRANSFERASE) 8 \\
\hline SETMAR & SET DOMAIN CONTAINING MAR \\
\hline SF3B1 & Splicing Factor $3 b$ \\
\hline SFRP1 & Secreted Frizzled-Related Protein 1 \\
\hline SFRP2 & Secreted Frizzled-Related Protein 2 \\
\hline
\end{tabular}


SFRP3

SFRP4

SFRP5

SMYD2

SMYD3

SYK

TAF10

TCR

TDL

TFF1

$T G F-\beta$

TP53

UnB

Var

VEGF

VHIg

WIF1

WNT

ZAP-70

$\Delta \mathrm{Cq}$

$\Delta \Delta \mathrm{Cq}$
Secreted Frizzled-Related Protein 3

Secreted Frizzled-Related Protein 4

Secreted Frizzled-Related Protein 5

SET and MYND domain-containing protein 2

SET and MYND domain-containing protein 3

Proteína tirosino quinase envolvida sinalização linfócitos $B$

TATA box binding protein (TBP)-associated factor

Receptor de antígeno T

Tempo de duplicação dos linfócitos

Factor de union a repetion telomero 1

Fator transformador do crescimento $\beta$

Gene ativador p53

Universidade de Brasília

Mitochondrial 37 S ribosomal protein VAR

Vascular endothelial growth factor

Imunoglobulina de cadeia pesada

WNT Inhibitory Factor 1

Via de sinalização intracelular associada à proliferação celular

Proteína zeta

Diferença entre o CTdo gene alvo e o CTde um gene endógeno

$\Delta \mathrm{CT}$ da amostra de interesse com o $\Delta \mathrm{CT}$ de uma amostra controle 
1.INTRODUÇÃO

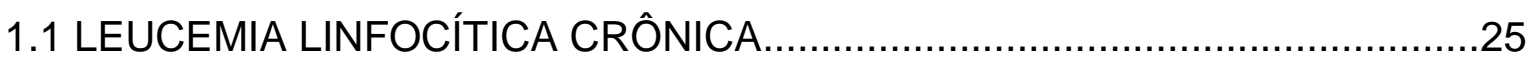

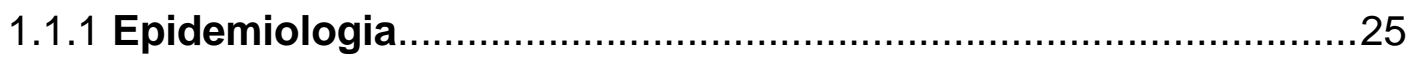

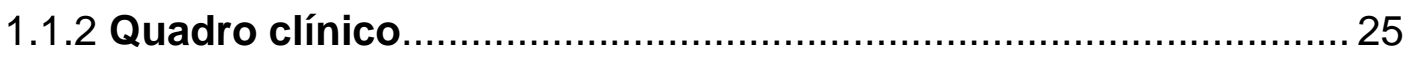

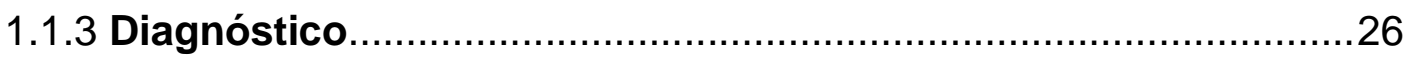

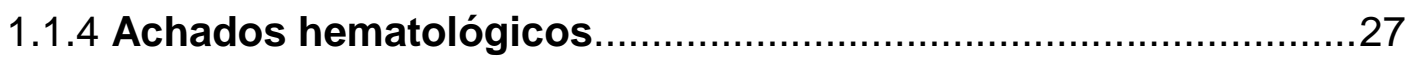

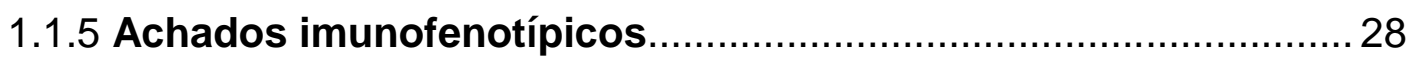

1.1.6 Achados citogenéticos e moleculares....................................29

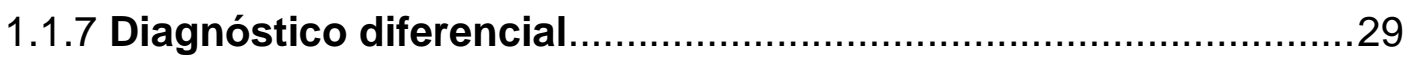

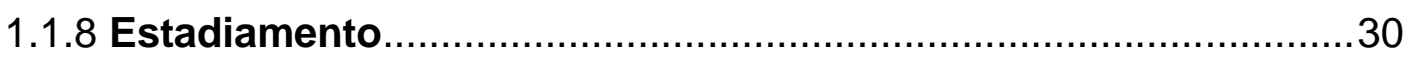

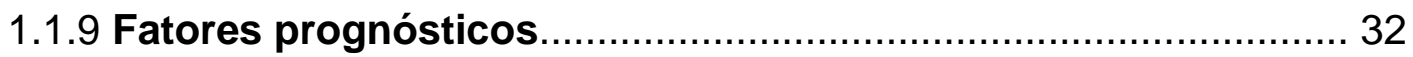

1.1.9.1 Aberraçoes citogenéticas.................................................. 34

1.1.9.2 Estadoexpressão do CD38............................................... 35

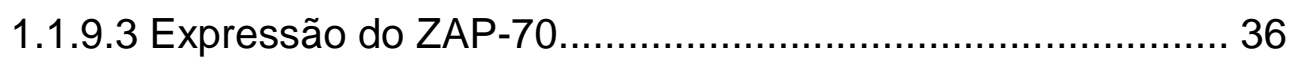

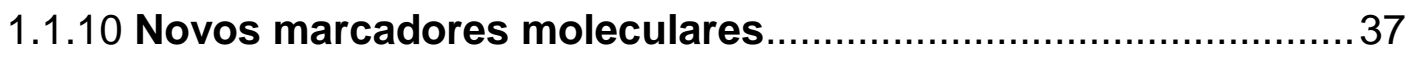

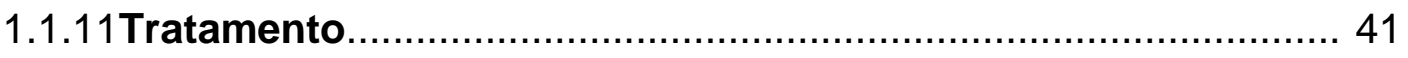

1.11.1Critérios para indicação do tratamento................................. 41

1.11.2 Novos alvos terapêuticos................................................... 43

1.2 ALTERAÇÕES PÓS TRADUCIONAIS DAS HISTONAS..................... 44

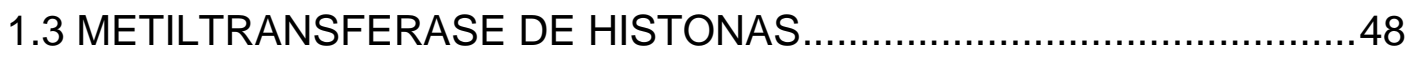

1.4 MECANISMOS EPIGENÉTICOS NAS NEOPLASIAS LINFÓIDES..... 52

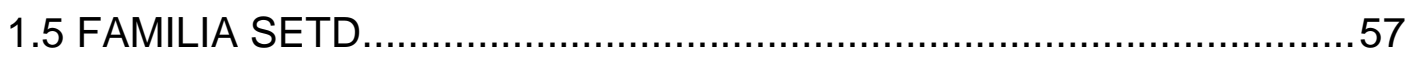


3. OBJETIVOS. 64

3.1OBJETIVOS ESPECIFICOS. 64

4. MATERIAIS E MÉTODOS. .65

4.1. AVALIAÇÃO DAS CARACTERÍSTICAS CLÍNICAS E PROGNÓSTICAS DAS AMOSTRAS DE PACIENTES PORTADORES DE LLC.

4.2. ANÁLISE DO PERFIL DE EXPRESSÃO DA FAMILIA SETD PCR EM TEMPO REAL NAS AMOSTRAS CLINICAS DE PACIENTES PORTADORES LLC.

4.3. ANÁLISE DOS DADOS POR PCR EM TEMPO REAL

4.4. CORRELAÇÃO DO NIVEL DE EXPRESSÃO DOS GENES DA FAMILIA SETD COM FATORES PROGNÓSTICOS CLASSICOS DA LLC

4.5. CONFIABILIDADE DOS RESULTADOS COM PADRÃO DE EXPRESSÃO INTERNACIONAL

5. RESULTADOS.

5.1. CARACTERÍSTICAS EPIDEMIOLÓGICAS DOS PACIENTES PORTADORES DE LLC

5.2. EXPRESSÃO GÊNICA DA FAMILIA SETD EM AMOSTRAS DE PACIENTES PORTADORES DE LLC.

5.3. PERFIL DE EXPRESSÃO GÊNICA DE SETD1A NAS AMOSTRAS DELLC.

5.4. PERFIL DE EXPRESSÃO GÊNICA DE SETD1B NAS AMOSTRAS DELLC.

5.5. PERFIL DE EXPRESSÃO GÊNICA DE SETD2 NAS AMOSTRAS DE LLC 
5.6. PERFIL DE EXPRESSÃO GÊNICA DE SETD3 NAS AMOSTRAS DE LLC.

5.7. PERFIL DE EXPRESSÃO GÊNICA DE SETD4 NAS AMOSTRAS DE LLC

5.8. PERFIL DE EXPRESSÃO GÊNICA DE SETD5 NAS AMOSTRAS DE LLC 93

5.9. PERFIL DE EXPRESSÃO GÊNICA DE SETD6 NAS AMOSTRAS DE LLC.

5.10. PERFIL DE EXPRESSÃO GÊNICA DE SETD7 NAS AMOSTRAS DE LLC.

5.11. PERFIL DE EXPRESSÃO GÊNICA DE SETD8 NAS AMOSTRAS DE LLC.

5.12. PERFIL DE EXPRESSÃO GÊNICA DE SETMAR NAS AMOSTRAS DE LLC

6. DISCUSSÃO. 113

7. CONCLUSÃO. 118

8. REFERÊNCIAS BIBLIOGRÁFICAS. 119 


\section{INTRODUÇÃO}

\subsection{LEUCEMIA LINFOCÍTICA CRÔNICA}

\subsubsection{Epidemiologia}

A leucemia linfocítica crônica (LLC) é mais comum das doenças linfoproliferativas crônicas. Quase $70 \%$ dos pacientes portadores estão acima de 65 anos no momento do diagnóstico, sendo rara (apenas $10 \%$ dos casos) em pessoas com menos de 50 anos. A incidência anual é de dois a seis casos por 100 mil habitantes, aumentando com a idade, chegando a 12,8 casos por 100 mil habitantes aos 65 anos e a 30 casos por 100 mil acima dos 80 anos (1).

Nos países ocidentais, a LLC-B representa 30\% de todas as leucemias, em contraste com os países asiáticos, onde corresponde a apenas $5 \%$ do total. Esta patologia é duas vezes mais comum em homens do que mulheres (na proporção de 2:1), mais comum em brancos que negros americanos, raro em hispânicos e nativos americanos e muito raro na população asiática (2).

No Brasil, há poucos dados sobre incidência e prevalência da LLC, as estatísticas disponíveis fazem as análises englobando todos os casos de leucemias agudas e crônicas (2).

A etiologia da LLC é desconhecida. A existência de casos familiares sugere uma predisposição genética, pelo menos em alguns pacientes. Fatores ambientais representados pela exposição a agentes químicos e derivados do petróleo estão associados ao aumento do risco para a doença (3).

\subsubsection{Quadro clínico}

A maioria dos pacientes é assintomática por ocasião do diagnóstico e muitas vezes a presença da linfocitose é identificada em exames de rotina. Nos pacientes sintomáticos, os achados mais comuns são linfonodomegalias generalizadas, perda de peso e cansaço. Os linfonodos geralmente são pequenos, mas podem ser volumosos formando lesões bulky (acima de $10 \mathrm{~cm}$ ). Hepatoesplenomegalia é detectada em $50 \%$ dos pacientes. A esplenomegalia é volumosa e o infarto esplênico 
é raro. Achados como anemia intensa e petéquias denotando sinais de hematopoese ineficaz por infiltração medula maciça são raros. As infecções bacterianas oportunistas são achados frequentes e estão relacionados a hipogamaglobulinemia presente em cerca de $50 \%$ desses pacientes (2).

Em 3 a 15\% dos casos durante a evolução da doença ocorre a síndrome de Richter, caracterizada na maioria das vezes pelo aparecimento de um linfoma difuso de grandes células, podendo se manifestar por febre, emagrecimento, sudorese, aumento da linfoadenopatia, anemia, trombocitopenia e gamopatia monoclonal. $\mathrm{O}$ prognóstico da síndrome de Richter é muito ruim, com sobrevida mediana de seis meses. Em menos de 1\% dos casos ocorre a evolução para linfoma de Hodgkin (4). Adicionalmente, em menos de $1 \%$ das LLC ocorre aparecimento de outras neoplasias associadas como mieloma múltiplo, leucemias agudas e carcinomas (5).

\subsubsection{Diagnóstico}

Nas últimas três décadas, vários critérios diagnósticos foram propostos, porém o mais utilizado são os critérios estabelecidos e revisados pelo National Cancer Institute (3) e pelo The International Worshop on LLC (6) que englobam:

a) presença de linfocitose em sangue periférico $>5.000$ por $\mathrm{mm}^{3}$ com expressão de pelo menos um marcador de células B por citometria de fluxo(CD19, CD20, CD23) e o marcador de célula B de memória CD5;

b) menos de $55 \%$ prolinfócitos no sangue periférico;

c) linfocitose na medula óssea (MO) igual a $30 \%$.

Para consolidar o diagnóstico e prognóstico da LLC devem-se associar além dos critérios descritos acima os achados morfológicos, imunológicos, cromossômicos e moleculares. 


\subsubsection{Achados hematológicos}

O achado hematológico mais frequente é linfocitose persistente. Morfologicamente, as células da LLC são linfócitos pequenos com núcleo redondo, cromatina densa e citoplasma escasso. As membranas citoplasmáticas e nuclear são regulares, com citoplasma fracamente basofilico (2). É comum a visualização de células rompidas, as manchas de Grumprecht, no esfregaço de sangue periférico da maioria dos pacientes, porém não existe uma explicação clara desta formação (Figura 1).

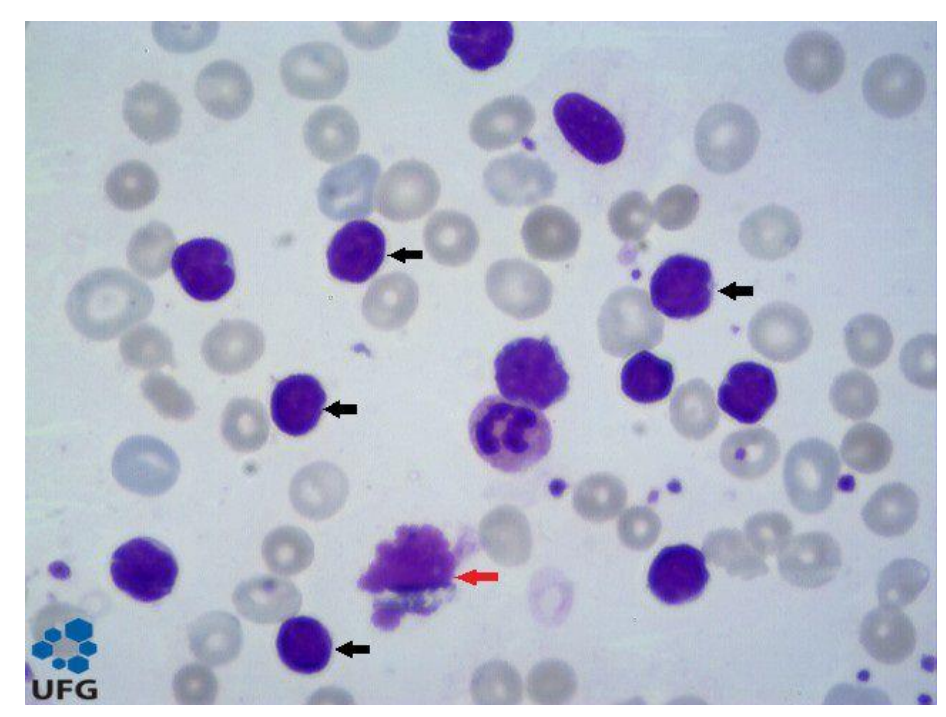

Figura 1- Esfregaço de sangue periférico de uma paciente com diagnostico de LLC evidenciando a presença das manchas de Grumpecht (setas vermelhas) e linfócitos leucêmicos típicos (setas pretas) Adaptado da www.ufg.gov.br).

Aproximadamente, $20 \%$ dos pacientes apresentam anemia ou trombocitopenia. A medula óssea está infiltrada por mais de $30 \%$ de linfócitos. Fenômenos de autoimunidade são bastante frequentes. Assim, anemia hemolítica autoimune ocorre em 10 a $25 \%$ dos casos e pode ser desencadeada pelo tratamento, principalmente sob uso de fludarabina, sendo o teste da antiglubulina direta positivo em $35 \%$ dos pacientes. Trombocitopenia (plaquetopenia) imune é observada em menos de $2 \%$ dos casos, enquanto que a neutropenia imune a aplasia pura de série vermelha são ainda mais raras. A hipogamaglobulinemia é comum e agrava-se com a evolução da doença, podendo ser detectada em $60 \%$ dos casos $(2,4,5,6)$. A LLC pode ser dividida em três diferentes subgrupos conforme a percentagem de células linfóides atípicas no sangue periférico: 
a) Típica ou clássica: em que a maioria das células linfoides são pequenas e maduras de linfócitos atípicos e prolinfociticos;

b) LLC com transformação prolinfocitica: apresenta entre 11 a $54 \%$ de prolinfocitos no sangue periférico;

c) Mista: apresenta proporção variável de células linfoides atípicas, mas os prolinfocitos constituem menos de $10 \%$ do total.

\subsubsection{Achados imunofenotípicos}

A LLC possui um fenótipo diferente das demais doenças linfoproliferativas B crônicas. Os linfócitos das LLC são da linhagemB e comumente expressão CD5, CD19, CD20, CD21, CD23, CD24, CD37 e não expressam CD103, CD10, CD79b e ciclina D1. O CD22 é ausente ou de baixa expressão. A expressão do CD20 é importante na diferenciação de outras neoplasias linfóides B crônica CD5+, principalmente o linfoma do manto, onde se marcador é negativo. Esses achados imunofenotípicos únicos são compostos em um sistema de pontuação que é útil para distinguir a LLC de outras doenças linfoproliferativas B crônicas $(2,5,6,7)$. Na LLC, $87 \%$ dos casos tem score 4 ou $5 ; 10 \%$ score $3,3 \%$ score 2 e $<1 \%$ score 0 ou 1 (Tabela 1).

Tabela 1- Critérios para diagnostico de LLC com base no sistema de pontuação proposto por Matutes et al, 1994 (7).

\begin{tabular}{lll}
\hline Marcador & Pontos 1 & Pontos 0 \\
\hline CD5 & Positivo & Negativo \\
CD23 & Positivo & Negativo \\
Cd79b-cd22 & Negativo-positivo & Moderado-forte \\
FMC7 & Negativo & Positivo \\
SIG & Fraco & Moderado-forte \\
Pontuação & $3,4,5$ & $0,1,2$ \\
Diagnóstico & LLC & Outras doenças \\
& & linfoproliverativas Bcrônicas
\end{tabular}




\subsubsection{Achados citogenéticos e moleculares}

$\mathrm{Na}$ LLC, as células $\mathrm{B}$ malignas apresentam baixo índice mitótico in vivo e também respondem pouco a presença de agentes mitóticos dificultando assim a análise citogenética clássica. Entretanto, com o desenvolvimento de técnicas de fluorescência associados a hibridização in situ (FISH) ocorreu melhora na detecção de algumas anormalidades cromossômicas, em relação a citogenética convencional. A maioria dos estudos mostra que, pela citogenética convencional, 50 a $60 \%$ dos pacientes com LLC apresentam alguma anormalidade cromossômica. Recentemente, foi demonstrado por hibridização in situ que mais de $80 \%$ dos casos apresentam alterações citogenéticas $(4,8)$.

A trissomia do cromossomo 12 é a anormalidade mais frequente sendo observada em um terço dos pacientes. A segunda anormalidade cromossômica mais encontrada é alteração estrututal do braço longo do cromossomo 13, com uma alta frequência para deleções e translocações envolvendo o locus13q14 onde esta localizado o gene do retinoblastoma (RB1). Outras anormalidades estruturais como deleção do 11q, deleção do 17p e deleção $6 q$ são pouco frequentes na LLC $(8,9)$.

\subsubsection{Diagnóstico diferencial}

O diagnóstico diferencial entre LLC e outras doenças linfoproliferativas de células $B$ (DLPCB) é importante, devem ser consideradas também outras leucemias crônicas de células $B$ e T, bem como a fase leucêmica dos linfomas não Hodgkin ( $(L N H)(3,4$, 7). Para diagnóstico diferencial acurado devem ser avaliados o quadro clínico, as características citogenéticas, imunofenotípicas e anormalidades moleculares das células leucêmicas (8).

Nos casos onde é observado linfocitose elevada, deve ser considerado o diagnostico diferencial entre a LLC, a Leucemia Prolinfocitica ou forma variante de leucemia de células cabeludas ou tricoleucemia (hairy cell). Na segunda grande maioria dos casos os critérios morfológicos e imunofenotipicos são suficientes para que o diagnostico diferencial seja estabelecido. Tanto as células da leucemia prolinfocititca como as da tricoleucemia não expressão CD23 e CD5, as células 
leucêmicas da tricoleucemia, morfologiamente apresentam linfócitos pilosos, com positividade para CD103 $(2,5,8)$. A tabela 2 mostra o perfil imunofenotípico das doenças linfoproliferativas B crônicas $(2,5,8)$.

Tabela 2- Perfil imunofenotipico das doenças linfoproliferativas cronicas de celulas B e dos linfocitos da LLC.

\begin{tabular}{lllllllll}
\hline & LLC & LPL & LCM & LF & HCL & LE & LLP & LDGC \\
\hline CD19 & ++ & ++ & ++ & ++ & +++ & ++ & ++ & ++ \\
CD20 & + & +++ & ++ & ++ & +++ & ++ & ++ & ++ \\
CD5 & ++ & + ou- & ++ & - ou + & - & - ou + & - ou + & - ou + \\
CD10 & - & - ou + & - & & ++ & - & - & + ou- \\
CD11C & + & - ou + & - & - & ++ & + ou- & - ou + & \\
CD22 & - out & ++ & ++ & + ou- & +++ & ++ & + & + \\
CD23 & ++ & - ou+ & - & - out & - & - & - & \\
CD25 & - out & + ou- & - & - & +++ & + ou- & - out & \\
CD79b & - out & ++ & ++ & ++ & ++ & ++ & + ou- & \\
FMC7 & - out & + & + & + & + & + & + & \\
CD103 & - & - & - & - & +++ & + ou- & - & \\
CD138 & - & - & - & - & - & - & - & - \\
Slg & - out & +++ & ++ & ++ & +++ & ++ & + & + \\
\hline
\end{tabular}

(+)Expressão fraca, $(++)$ expressão moderada, $(+++)$ expressao forte, $(-)$ ausencia de expressao, $(-\mid+)$ marcador expresso em menos de $50 \%$ dos casos, $(+\backslash-)$ marcador expresso na maioria dos pacientes.

O linfoma de células do manto é um tipo de DLPCB cuja expressão aumentada da ciclicna D1 e negatividade do CD23 fazem diferença entre este tipo de linfoma e LLC, muitas vezes o diagnóstico diferencial com LLC é dado pela presença da translocação $t(11: 14)(q 13 ; q 32)(5,8)$.

\subsubsection{Estadiamento}

O curso clínico da LLC é bastante variável. Alguns pacientes são assintomáticos e sobrevivem por longos períodos sem necessidade de terapia, enquanto outros evoluem rapidamente apesar de tratamento agressivo. Em 1966, alguns autores 
observaram que pacientes com sobrevida menor do que 5 anos tinham mais manifestações clinicas ao diagnóstico quando comparados com os que sobreviviam por um período longo e que o rápido aumento do número absoluto de linfócitos no sangue periferico estava correlacionado com uma rápida progressão clínica da doença $(10,11)$.

Baseando-se nas características clinicas, tais como aumento de linfonodos, presença ou ausência de esplenomegalia, hepatomegalia e avaliação do sangue periférico vários sistemas de estadiamento clinico foram propostos para identificar a extensão da doença nos pacientes com LLC, avaliar o prognóstico e desta forma programar melhor a estratégia terapêutica (10). Os dois sistemas mais utilizados na prática clínica são o sistema de estádio clinico de Rai (10) e o de Binet et al (11).

O sistema proposto por Rai et al (10) considerava: a) linfocitose absoluta maior do que $15.000 / \mathrm{mm}^{3}$ em sangue periférico associada ou não a adenomegalias, esplenomegalia, hepatomegalia; b) anemia definida como taxa de hemoglobina menor que $11 \mathrm{~g} / \mathrm{dl}$; c) plaquetopenia definida como contagem de plaquetas menor que $100.000 / \mathrm{mm}^{3}$. Esse sistema classificava os pacientes em 5 categorias de 0 a IV (Tabela 3).

Tabela-3 Sistema de estádio clinico proposto por Rai (10).

\begin{tabular}{lllll}
\hline Estádio & $\begin{array}{l}\text { Áreas } \\
\text { comprometidas }\end{array}$ & $\mathbf{H b}$ (gldl) & $\begin{array}{l}\text { Plaquetas } \\
\text { Imm3 }\end{array}$ & Prognóstico \\
\hline $\mathbf{0}$ & Não & $>11,0$ & $>100.000$ & Baixo risco \\
I & Linfonodos & $>11,0$ & $>100.000$ & $\begin{array}{l}\text { Risco } \\
\text { intermediário }\end{array}$ \\
II & Fígado ou baço & $>11,0$ & $>100.000$ & $\begin{array}{l}\text { Risco } \\
\text { intermediário }\end{array}$ \\
& & & & Alto risco \\
III & Indiferente & $<11,0$ & $>100.000$ & Alto risco \\
IV & Indiferente & Indiferente & $<100.000$ &
\end{tabular}


Em 1987, esse sistema foi modificado pelos mesmos autores e os estádios foram divididos em 3 categorias prognósticas conforme descrita na tabela 3: estádio 0 (baixo risco), estádio I e II (risco intermediário) e estádio III e IV (alto risco).

O sistema de estádio clinico de Binet $(5,6,11,12)$ subdividide os pacientes em três categorias (Tabela 4). Os pacientes em estádio clinico A são considerados baixo risco e clinicamente sem evidências de anemia ou plaquetopenia e com até duas cadeias ganglionares afetadas. Os pacientes em estádio clinico B diferem do grupo A por apresentarem três ou mais cadeias ganglionares comprometidas e são consideradas de risco intermediário. Os pacientes classificados como estádio $C$ apresentam anemia e plaquetopenia.

Tabela 4- Sistema de estadio clínico proposto por Binet (11).

\begin{tabular}{llllll}
\hline Estádio & $\begin{array}{l}\text { Áreas } \\
\text { comprometidas }\end{array}$ & $\mathbf{H b}(\mathbf{g} \backslash \mathbf{d} \mathbf{l})$ & $\begin{array}{l}\text { Plaquetas } \\
\mathbf{\mathbf { m m } ^ { 3 }}\end{array}$ & $\begin{array}{l}\text { Sobrevida } \\
\text { médias } \\
\text { (anos) }\end{array}$ & Prognóstico \\
\hline A & $<3$ areas & $>10,0$ & $>100.000$ & $>10$ & Baixo risco \\
\hline B & $=3$ areas & $>10,0$ & $>100.000$ & 7 & $\begin{array}{l}\text { Risco } \\
\text { intermediário }\end{array}$ \\
\hline C & Indiferente & $<10,0$ & $=100.000$ & 1,5 & Alto risco \\
\hline
\end{tabular}

\subsubsection{Fatores prognósticos}

Esses dois sistemas de estádios clínicos, descritos por Rai $(11,13)$ e Binet (11), são amplamente utilizados como importantes fatores preditivos de sobrevida em pacientes com LLC. Entretanto, seu valor prognóstico é limitado nos estádios da doença.

Vários estudos demonstraram que o tempo de duplicação dos linfócitos (TDL) é um indicador prognóstico da LLC. Pacientes com TDL inferior ou igual a 12 meses tem sobrevida menor comparado aqueles em que o TDL é superior a 12 meses e que apresentam sobrevida maior (14).

O padrão de envolvimento da medula óssea por células leucêmicas também divide os pacientes com LLC em dois grupos, com prognóstico distintos. Pacientes com padrão de infiltração difuso apresentam uma sobrevida média de 2 a 4 anos, enquanto 
que os pacientes com padrão de infiltração nodular e intersticial tem sobrevida de 8 a 10 anos $(14,15)$.

Foi reconhecido que os sistemas de estadiamento clínico Rai ou Binet por si só não são suficientes para estimar o prognóstico indivíduo, particularmente em pacientes com doença em estágio inicial (por exemplo, Binet A,Rai estadio 0-II). Portanto, os parâmetros adicionais têm sido procurado para avaliar com mais precisão o prognóstico dos pacientes com LLC. Vários pesquisadores tem fornecido um número cada vez maior de exames laboratoriais, que predizem a resposta ao tratamento, progressão sobrevida livre ou a sobrevida global dos pacientes com leucemia linfocítica crônica. Em análises retrospectivas prévias, os parâmetros mostrados naTabela 5 têm evidenciado resultados promissores, o que justifica maiores investigações em estudos prospectivos.

No entanto, os métodos para a medição de alguns destes parâmetros (como: ZAP70, marcadores citogenética, o estado mutacional de imunoglobulinas) não são prontamente exequível na maioria dos laboratórios clínicos. Além disso, o valor prognóstico de alguns dos marcadores mais facilmente acessíveis (por exemplo, beta 2 microglobulina) não tem sido bem estabelecida como a do estado mutacional da imunoglobulina ou de certas anomalias citogenéticas (por exemplo, deleção 17) $(14,15)$.

Tabela 5- Marcadores de agressividade da LLC em relação ao prognóstico.

\section{Parâmetro}

Aberrações nos cromossomos 11 (11q-) ou 17 (9)
(17 p-)

\section{Referência bibliográfica}

Estado não mutado imunoglobulina VH-genes $(15,16)$

Expressão de ZAP-70 $\quad(17,18,19)$

Tempo de Duplicação linfocitária inferior a 12 (14) meses

Elevação nos níveis séricos de $\boldsymbol{\beta 2}-(20,21,22)$
microglobulin




\subsubsection{Aberrações citogenéticas:}

Em relação as anormalidades cromossômicas dos pacientes, a presença de cariótipo normal e a deleção 13q14 ou trissomia do 12 estão correlacionados com melhor prognóstico. Por outro lado, uma proporção dos pacientes com deleção 17q13 ou deleções do 11q23 tem pior prognóstico (9). Mutações ou deleções do gene TP53 (encontrado em pacientes com deleção 17p) estão envolvidos com mecanismo de controle do ciclo celular, reparo DNA e apoptose. Assim como, a expressão aumentada do gene MDM-2 (inativador do P53) está associado a estadios mais avançados da LLC $(4,6)$. Utilizando as técnicas de hibridização por fluorescência (FISH),muitas alterações citogenéticas podem ser identificadas em mais de $80 \%$ dos casos. As aberrações cromossômicas freqüentes incluem: trissomia do cromossomo12, deleções no braço longo do cromossomo 11[del (11q)] ou 6[del (6q)], ou no braço curto do cromossoma 17[del (17p)].Certas translocações podem ajudar a distinguir outras doenças linfoproliferativas da LLC, por exemplo, $t(11 ; 14)$ presente no linfomade células do manto $(4,9,23,24)$.

As deleções do 11q resulta na perda do gene ATM que exerce importante papel na sinalização do dano DNA com consequente ativação p53, a qual por sua vez é capaz de iniciar processo de apoptose celular $(4,6,9)$.

Recentemente, vários estudos clínicos prospectivos evidenciam que a detecção de certas exclusões cromossômicas tem significância prognóstica. Os pacientes com células de leucemia que têm del(17p) tem um prognóstico inferior e parecem relativamente resistentes à certos regimes de quimioterapia contendo fludarabina (análago de purinas) $(5,9,12)$. Em uma análise retrospectiva, os pacientes com LLC que apresentavam aberrações cromossômicas como del(11q) ou del(17p) tiveram uma sobrevida global inferior em comparação com os pacientes com um cariótipo normal ou del (13q) como única anormalidade (9).Por outro lado, os pacientes com del(17p) pode respondem à terapia com alemtuzumab e atualmente podem responder ao ibrutinib, quer isoladamente ou em combinação. Nos ensaios clínicos, recomendase que a citogenética deva ser realizada antes de se tratar de um doente em protocolo quimioterápico. Anormalidades citogenéticos adicionais podem ser adquiridas durante o curso da doença $(24,25,26,27)$. Assim, a repetição de análise $F I S H$ parece justificarse antes do tratamento subsequente, de segunda ou terceira linha (27). 


\subsubsection{Estado mutacional da imunoglobulina e expressão do CD38}

A LLC é caracterizada pelo acúmulo de uma população clonal de celulas $B$ com expressão do $\mathrm{CD} 5+$. Inicialmente essas células foram consideradas como linfocitos $B$ virgens, entretanto dados recentes mostramque pelo menos metade dos casos de LLC representam expansao clonal de celulas pos centro germinativo ou celulas $B$ de memória. Essas conclusões foram baseadas no estudo do sequenciamento dos genes da região variável da cadeia pesada da $\mathrm{lg}$ (VHIg), onde foram enconstradas um número significante de mutações somáticas nesses genes $(15,16,28)$. As células $B$ com mutações somáticas inferiores a $2 \%$ são classificadas como não mutadas (NVHIg), enquanto que aquelas com mutações somáticas superior ou igual a $3 \%$ sao consideradas mutadas (NVHIg)(25).

Muitos autores descrevem que a avaliação dos estado mutacional do gene da região variável da cadeia pesada da imunoglobulina (VHIg) pode ser considerada um marcador prognóstico na LLC. As mutações somáticas nesse gene da imunoglobulina são observados em aproximadamente metade dos casos de LLC e dividem os pacientes em 2 grupos: a) com mutação somática do gene VHlg correlacionados com melhor prognóstico ; b) outro gupo sem mutações somáticas do gene da VHlg e que apresentam pior prognóstico. $(28,29)$.

A detecção de mutações somáticas no gene da VHlg é tecnicamente difícil e somente disponível em alguns laboratórios de pesquisa. Desse modo, a identificação de um marcador substituto para o estudo do sequenciamento do gene VHIg seria importante. Estudos mostram que a expressão do CD38 na superfície das células leucêmicas poderia estar relacionado com estado mutacional do gene VHlg e a sobrevida dos pacientes com LLC. Assim, as células B da LLC com mutação somática nos genes da VHlg e associados com baixa ou nenhuma expressão de CD38, poderiam exibir um curso clínico favorável da doença. Por outro lado, os casos sem mutação somática no gene da VHIg e com alta expressão do CD38 exibiam um pior prognóstico (16). A expressão pode variar durante o curso da doença, isto é, ela pode aumentar na progressão da doença ou na vigência de processo infeccioso (23). A expressão do CD38 na porcentagem acima de 30\% é considerada como elevada sendo então taxado como de pior prognóstico por muitos autores $(23,28,29)$. 


\subsubsection{Expressão da ZAP-70}

ZAP-70 é uma proteína membro da família tirosina quinase (PTK) normalmente expressa em linfócitos $T$ e nas células NK e que desempenha um papel essencial na ativação dos linfócitos T através do receptor de antígeno T (TCR). Após a estimulação do receptor de células T ocorre a interação da ZAP-70 com o complexo TCR $\backslash C D 3$, ativando a cascata de sinalização dos linfocitos $T(17,18,30)$. As células $B$ de indivíduos normais, normalmente não expressão ZAP-70. Essas células utilizam outra proteína da família tirosina quinase, a Syk, para a ativação dos linfócitos $B$ pelo complexo do receptor de células $B(B C R)$. As proteínas ZAP-70 e Syk têm papéis semelhantes na sinalização do receptor de antígeno na membrana celular, entretanto, o significado funcional da expressão de ZAP-70 nas células B da LLC ainda não é bem conhecido. A ligação do complexo $B C R$ nas células $B$ de pacientes com LLC, que expressam ZAP-70, induz um aumento da fosforilação de Syk e está associado com a imunglobulina de superficie e as moleculas CD79a e CD79b. Portanto, acredita-se que a expressão de ZAP-70 está associada com aumento da sinalização pelo complexo BCR e pode estar associado ao cursos mais agressivo da doença $(30,31,32)$.

Considerando a hipótese que a avaliação quantitativa da ZAP-70 poderia ser utilizada como um marcador substituto ao sequenciamento dos genes VHIg. Vários pesquisadores realizaram estudos comparativos entre a expressão intracelular de ZAP-70 (por citometria de fluxo e imunohistoquímica) e o estado mutacional da VHIg $(18,19)$. Esses autores verificaram que as células B de LLC com alta expressão de ZAP-70 não apresentavam mutações somáticas dos genes VHIg. Portanto, a expressão de ZAP-70 está correlacionada com estado não mutado do gene da VHIg sugerindo um pior prognóstico dos pacientes com LLC e infere que possa ser utilizada como um marcador substituto do sequenciamento gênico da VHIg $(18,19)$.

Resumidamente, os principais fatores prognósticos laboratoriais com impacto na evolução clinica e terapêutica oncológica estão listados na tabela $6(5,6,31,32,33)$. 
Tabela 6- Principais fatores prognósticos laboratoriais da LLC.

\begin{tabular}{lll}
\hline $\begin{array}{l}\text { Prognóstico favorável } \\
\text { Padrão de infiltração de } \\
\text { intersticial ou nodular }\end{array}$ & Prognóstico desfavorável \\
\hline Estado mutado da VHIg & Padrão de infiltração de MO difuso \\
\hline CD38 negativo & CD38 positivo \\
\hline TDL>12 meses & TDL<12 meses \\
\hline $\begin{array}{l}\text { ZAP-70 negativo (nível } \\
\text { expressão inferior a 20\%) }\end{array}$ & ZAP- 70 positivo (expressão acima de 20\%) \\
\hline $\begin{array}{l}\text { Del 13q14 } \\
\end{array}$ & Del 11q23, del 17p \\
\hline & P53 com expressao reduzida ou \\
\hline & disfuncional & \\
\hline & LDH elevado e b2 microglobulina elevada
\end{tabular}

TDL: tempo de duplicação linfocitaria, VGlg: região variável da imunoglobulina de cadeia pesada

\subsubsection{Novos marcadores moleculares}

Nos últimos anos, as abordagens genômicas têm sido aplicadas e revelaram alterações genéticas novas em LLC, principalmente as mutações: NOTCH1, SF3B1 e BIRC3. As alterações destes genes ocorrem em $2 \%-12 \%$ dos pacientes com LLC no momento do diagnóstico. No entanto, a sua prevalência aumenta durante fases avançadas da doença, conferindo um provável pior prognóstico $(32,33)$.

Recentemente foi publicado um novo sistema de avaliação prognóstica que engloba as alteraçoes citogenéticas e moleculares (incluindo as citadas acima), obtidas a partir de banco de amostras de pacientes com LLC em estadio precoce da doença e sem tratamento prévio (4). O objetivo dessa proposta foi agregar as novas mutaçoes recém descobertas com as alteraçoes cromossômicas conhecidas analisando dados de sobrevida dos pacientes em cinco e dez anos de evolução. As curvas de sobrevida global podem ser analisadas na tabela $7(4,32)$. 
Tabela 7- Sistema de avaliação prognóstica e molecular na LLC.

\begin{tabular}{|c|c|c|c|c|}
\hline Risco & $\begin{array}{l}\text { Número de } \\
\text { pacientes } \\
\text { (\%) }\end{array}$ & $\begin{array}{l}\text { Fatores } \\
\text { relacionados }\end{array}$ & $\begin{array}{l}\text { Sobrevida } \\
\text { em cinco } \\
\text { anos }\end{array}$ & $\begin{array}{l}\text { Sobrevida em } \\
\text { dez anos }\end{array}$ \\
\hline Alto & 27 & $\begin{array}{l}\text { Mutaçoes no } \\
\text { TP53 elou } \\
\text { BIRC3 }\end{array}$ & 51 & 29 \\
\hline Intermediário & 39 & $\begin{array}{l}\text { Mutaçoes no } \\
\text { NOTCH1 elou } \\
\text { SF3B1 elou del } \\
\text { 11q23 }\end{array}$ & 66 & 37 \\
\hline Baixo & 17 & $\begin{array}{l}\text { Citogenetica } \\
\text { normal ou } \\
\text { trissomia } \\
12(+12)\end{array}$ & 78 & 57 \\
\hline Muito baixo & 17 & Del $13 q 14$ & 87 & 69 \\
\hline
\end{tabular}




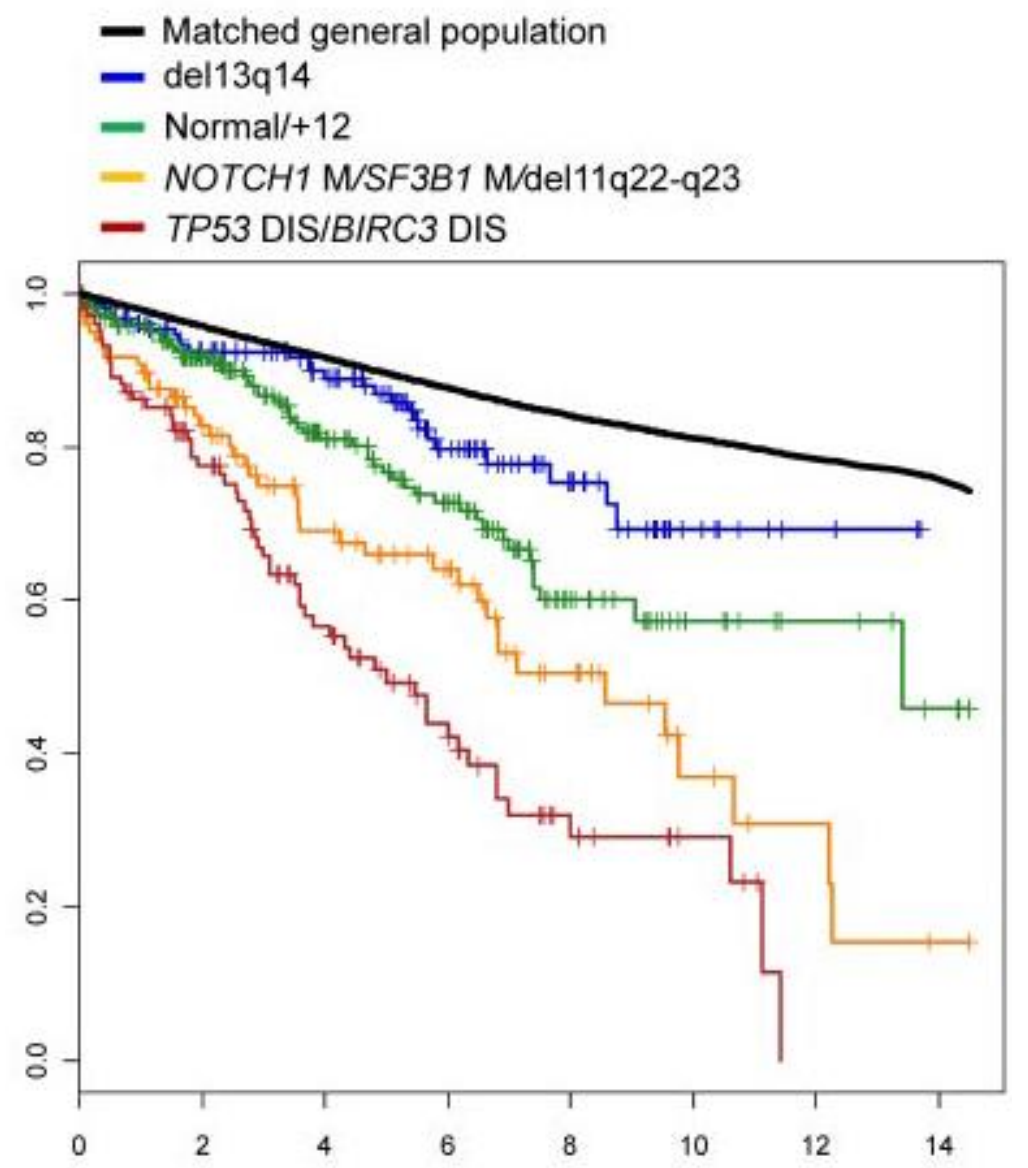

Figura 2- Curvas de sobrevida global de acordo com os grupos de risco determinados pelas alteraçoes citogeneticas e moleculares (adaptado de Gribben,2008) (32).

Os pacientes portadores TP53 e/ou BIRC3 (TP53 DIS/BIRC3DIS) independente de lesões genéticas concomitantes são representados pela linha vermelha (alto risco). Pacientes portadores de mutações Notch1 (NOTCH1 $M$ ) e lou mutações SF3B1SF3B1(M) e / ou del11q22-q23 na ausência deTP53 e BIRC3 são representados pela linha amarela (risco intermediário). Doentes possuindo+12, na ausência de TP53 e BIRC3, possuindo as mutações NOTCH1, mutações SF3B1 e del11q22-q23 e os pacientes com cariótipo normal são representadospela linha verde (baixo risco). Pacientes abrigando del13q14 como a única lesão genética são representados pela linha azul (muito baixo risco) $(4,32)$.

As mutações NOTCH1 são mais freqüentes encontradas em estadios avançados do que em iniciais, em pacientes politratados versus pacientes virgens de tratamento, exibem uma forte associação positiva com casos de LLC expressando 
imunoglobulina não mutada(VHIG) e em pacientes com forma transformada de LLC (Sindrome de Richter)(32,33).

As investigações recentes indicam que a relevância clínica das mutações SF3B1têm uma incidência menor em estadios iniciais da LLC,são mais comum na doença avançada, têm fortes associações com del (11q) e um pior desfecho clínico. Estes resultados sugerem fortemente a aquisição de mutações SF3B1 durante a evolução clonal dadoença. O significado clínico das mutaçoes em NOTCH1 e SF3B1 já foram validados em trials clínicos prospectivos $(33,34)$. Portanto, embora aberrações TP53 manteve-se o indicador mais informativo de pior evolução clínica, as mutações dentro NOTCH1 e SF3B1 foram identificados como biomarcadores independentes na diminuição da sobrevida global, consideradas potencialmente úteis paraa estratificação de risco dos pacientes com LLC.

Os resultados da análise mutacional dos pacientes arrolados no CLL8 (estudo clínico que avaliou terapia de primeira linha com Fludarabina e Ciclofosfamida ou Ciclofosfamida, Fludarabina mais Rituximab entre pacientes com LLC não tratados) confirmou que a mutação SF3B1 seria um fator independente para uma progressão mais rápida da doença (34). Consequentemente, alguns estudos sugerem que a presença da mutação em NOTCH1 pode conferir uma certa resistência ao efeito do rituximab (anticorpo monoclonal anti-CD20); no entanto, este achado deve ser confirmado em estudos independentes antes de ser aplicadas na prática clínica (35).

As mutações dentro BIRC3 são freqüentes em pacientes com LLC quimiorefratários a fludarabina (24\%) e raros no diagnóstico inicial (2\%-4\%). As análises genômicas utilizando sequenciadores de nova geraçao identificaram BIRC3 como um regulador negativo da via de sinalização para transcrição do $N F-k B$. Recentes estudos sugerem que as mutações no BIRC3 foram associados com quimiorefratariedade, pobre prognóstico similares aos portadores de anormalidade do TP53 $(4,36)$.

Recentemente estudos epigenéticos, identificaram que a superexpressão do gene EZH2 (metiltransferase de histona) em amostras de LLC esteve correlacionada com elevada contagem leucocitária, alta expressão de ZAP-70 e presença de anormalidades citogenéticas como trissomia 12 (35). 


\subsubsection{Tratamento}

\subsubsection{Critérios para indicação do tratamento}

Adecisão de se tratar os pacientes portadores de LLC é guiada pelo estadio clínico do paciente, atividade da doença, presença de anormalidades citogenéticas e moleculares. A decisão sobre qual esquema de tratamento será utilizado pode afetar favoravelmente sobre o resultado de sobrevida desses pacientes. Atualmente, é recomendado o tratamento quimioterápico para pacientes com Rai III-IV, Binet B-C ou para pacientes com evidência clara de rápidaa progressão da doença ou transformação em Sindrome de Richter. Os pacientes em estágios iniciais (Rai 0-II, Binet $A$ e B) geralmente não são tratados, mas monitorados com a estratégia de "observar e esperar" (tradução da recomendação internacional de "WATCH AND WAIT")(4,5,6).

Os pacientes emestágios intermediários (I e II) e alto risco (estágios III e IV), de acordo com a classificação Rai modificado ou pelo Binet fase B ou C $(4,5,6,12)$, usualmente se beneficiam do tratamento. Pelo menos um dos seguintes critérios devem ser respeitados:

a) A prova da falência da medula progressiva (citopenias sintomáticas) como manifestado pelo desenvolvimento ou agravamento da anemia ou trombocitopenia;

b) Hepatomegalia maciça (ou seja, pelo menos $6 \mathrm{~cm}$ abaixo da margem costal esquerda) ou esplenomegalia progressiva ou sintomática;

c) Linfoadenomegalia volumosa (ou seja, pelo menos $10 \mathrm{~cm}$ de diâmetro maior)ou linfadenopatia progressiva ou sintomática;

d) Linfocitose Progressiva com um aumento de mais de 50\% ao longo de um período de 2 meses ou tempo de duplicação dos linfócitos (TDL) de menos de 6 meses;

e) Anemia auto-imune e /ou trombocitopenia que é mal responsivos aos corticosteróides ou outra terapêutica padrão.

O curso clínico da LLC é altamente variável desde de uma rápida progressão da doença necessitando de tratamento precoce e freqüente, a uma sobrevivência 
durante décadas com tratamento mínimo. Mesmo com o tratamento e avanços moleculares em LLC tenha progredido significativamente nas últimas décadas (por exemplo, combinação quimioimunoterapia composta por fludarabina, ciclofosfamida e rituximab (FCR) com uma taxa de resposta de cerca de 90\%), a doença acaba permanecendo incurável, ou na melhor das hipóteses é terapeuticamente convertido em um doença crônica.

Novos conceitos a respeito da individualização do tratamento da LLC vem surgindo nos últimos anos como: tratamento avaliando a idade (pacientes "saudáveis ou não", da tradução das recomendações internacionais de "FIT ou UNFIT"), performance clínica, presença de comorbidades, presença de alterações citogenéticas e moleculares. Assim, os pacientes podem ser categorizados como clinicamente apto sem comorbidade ou leve comorbidades com uma expectativa de vida normal(“FIT"),e, portanto,potencialmente adequado para terapia intensiva, independente da idade cronológica (a terapêutica chamada "GO-GO" ); outro grupo seriam os menos aptos com múltiplas ou severas comorbidades e uma expectativa de vida desconhecida (a terapêutica chamada "SLOW-GO"); ou clinicamente frágeis com comorbidades fatais e uma curta expectativa de vida (“UNFIT"),e, portanto,não se beneficiem com tratamento para LLC ( terapêutica chamada "NO-GO") $(5,6,7)$. Na tabela 8, seguem as sugestões de tratamento para paciente fit e unfit e portadores de anormalidades citogenéticas de pobre prognóstico $(5,6,12)$.

Tabela 8- Sugestões terapêuticas para pacientes dom LLC.

\begin{tabular}{|c|c|c|c|c|}
\hline & Pacientes Fit & $\begin{array}{l}\text { Pacientes } \\
\text { Unfit }\end{array}$ & $\begin{array}{l}\text { Portadores } \\
\text { Del 17p- }\end{array}$ & $\begin{array}{l}\text { Portadores } \\
\text { Del 11q- }\end{array}$ \\
\hline $\begin{array}{c}\text { Primeira } \\
\text { linha de } \\
\text { tratamento }\end{array}$ & $\begin{array}{c}\text { Ofatumumab+clorambu } \\
\text { cil } \\
\text { Obinutuzuman+ } \\
\text { clorambucil } \\
\text { Rituximab + clorambucil }\end{array}$ & $\begin{array}{c}\text { Fludarabina+ } \\
\text { rituximab + } \\
\text { ciclofosfamida } \\
\text { Bendamustina } \\
\text { + rituximab }\end{array}$ & $\begin{array}{c}\text { Ibrutinib } \\
\text { Alemtuzumab } \\
+ \text { rituximab } \\
\text { RFC }\end{array}$ & $\begin{array}{c}\text { Obinutuzumab } \\
\text { + clorambucil } \\
\text { RFC }\end{array}$ \\
\hline Refratários & $\begin{array}{c}\text { Idesinib+ rituximab } \\
\text { Ibrutinib } \\
\text { Ofatumumab } \\
\text { Obinutuzumab }\end{array}$ & $\begin{array}{l}\text { ibrutinib } \\
\text { Idelalisib+ } \\
\text { rituximab }\end{array}$ & & \\
\hline
\end{tabular}




\subsubsection{Novos alvos terapêuticos}

O reconhecimento de queo receptorde células $B(B C R)$ é essencial para a proliferação e sobrevivência de leucemia linfocítica crónica destaca-se como uma importante descoberta na fisiopatologiada doença $(32,33)$. Sugere-se que os marcadores moleculares correlacionados com pior prognóstico como: imunoglobulina não mutada de cadeia pesada (NVHIg) e a expressão do ZAP-70, estão associados com a atividade de sinalização do BCR, sugerindo uma progressão mais rápida da doença quando expressos.

O exame das células de LLC na medula óssea e linfonodos demonstra que a via BCR é ativado ocasionando uma maior proliferação de células tumorais. Mais recentemente, quinases ligadas ao gene $\mathrm{BCR}$, incluindo uma tirosinaquinase esplenica(SYK), tirosino quinase de Bruton e fosfatidilinositol 3-quinase(PI3K), foram encontrados ativadasna maioria dos pacientes com LLC. Estas quinases e sua amplificação, tais como tirosina-quinase de Bruton(BTK) aparecem essenciais não só para a ativação de sobrevivência múltipla vias (AKT, ERK, FATORNUCLEARKB), mas também para quimiomediação, migração e adesão de células $B$ no microambiente (37).

Várias moléculas têm sido desenvolvidos para inibir uma variedade de quinases da via de BCR, incluindo $L Y N$, SYK, BTK e PI3K,com especificidade variada. A inibição farmacológica destas quinases (target therapy) promove a apoptose de células LLC in vitro. Após tratamento com ofostamatinib(inibidorSYK13, sendo o primeiro agente de $\mathrm{BCR}$-alvo), apresentou-se uma rápida reduçãono volume nodal, redução dos sintomas de progressão da doença e das citopenias. Esses efeitos foram acompanhados por uma chamada "Linfocitose redistribuição." Este fenômeno é agora reconhecida como um efeito da classe dos antagonistas do BCR, apoiando ainda mais o papel BCR na sinalização para retenção de células da LLC no seu microambiente e contribuindo para controle da doença $(33,37)$.

O surgimento de biodisponível oral da classe dos inibidores de quinases BCR (dirigidos a BTK e a isoforma do PI3K) representam um avanço terapêutico na LLC. Idelalisib é a primeira classe de inibidor oral seletivo da isoforma de PI3K delta. Os trabalhos pré-clínicos demonstraram que inibição da PI3K delta é capaz de induzir 
apoptose das células da LLC e outras células B, diminuindo a sobrevida das células da LLC (37).

Outro inibidor da BTK na testado na prática clínica foi o ibrutinib. A mutação de BTK também ocorre naturalmente no organismo humano, resultando em um fenótipo caracterizado por uma doenças chamada de agamaglobulinemia de Bruton. A BTK é ativada pela SYK e inicia a proliferação, migração e acomodação das células B no micromabiente tissular. Os trabalhos pré-clínicos com ibrutinib (inibidor da BTK)em LLC demonstraram tanto a inibição da via intrínseca e extrínseca mediada por BTK das células $B$, diminuição das células leucemicas in vitro, prevenção da migração das celulas de LLC para microambiente tissular e regressão tumoral dos linfomas de células B em modelos animais(32,37).

A próxima geraçãodos anticorpos monoclonais (mAb) tal como, obinutuzumab (anti-CD20 humanizado como mAblgG1 uma região Fc) representa novas opções naterapia com os anticorpos monoclonais. Em combinação como clorambucil, o obinutuzumab foi comparado com a associação entre rituximab e clorambucil no tratamento de pacientes idosos e portadores de comorbidades. Os dados deste estudo mostram benefícios em resposta terapêutica e menor toxicidade no grupo tratado com obinutuzumab e ressalta a importância de caracterizar os pacientes"fit" por meio de uma avaliação abrangente das comorbidades, estado funcional global e o benefício do tratamento $(31,32,37)$.

\subsection{EPIGENÉTICA E ALTERAÇOES PÓS TRADUCIONAIS DAS HISTONAS}

O ácido desoxirribonucleico (DNA) genômico se encontra compactado no núcleo das células eucarióticas. Essa compactação ocorre com auxílio de proteínas histonas e proteínas não histonas em um polímero dinâmico chamado cromatina. A cromatina possui regiões altamente condensadas, denomindadas heterocromatinas e regiões menos condensadas, denominadas eucromatinas. As heterocromatinas são pobres em genes expostos a maquinaria de transcrição e, portanto, são transcricionalmente silenciadas. As eucromatinas são ricas em genes expostos a maquinaria de transcrição e mais facilmente transcritas (38). As proteínas envolvidas na regulação 
de estruturas da cromatina podem, portanto, funcionar como determinantes importantes de processos do desenvolvimento.A atividade de um gene é dependente tanto do repertório de fatores de transcrição disponível quanto do local de empacotamento do DNA na cromatina (39).

A cromatina pode apresentar diferentes níveis de compactação devido as suas unidades principais: os nucleossomos. O nucleossomo é a unidade básica de um cromossomo eucarioto, consistindo em 146 pares de base de DNA enovelados em torno de um núcleo constituído por um octamero de proteínas conhecidas como histonas. As proteínas histonas ( $\mathrm{H} 3, \mathrm{H} 4, \mathrm{H} 2 \mathrm{~A}, \mathrm{H} 2 \mathrm{~B}$ e H1) são altamente conservadas e o octâmero de histonas consiste em um tetrâmero de $\mathrm{H} 3-\mathrm{H} 4$, dois dímeros de $\mathrm{H} 2 \mathrm{~A}$ $\mathrm{H} 2 \mathrm{~B}$ e a histona $\mathrm{H} 1$ atua como estabilizadora da estrutura (38). As histonas são constituídas por um domínio globular e uma porção $\mathrm{N}$-terminal mais flexível e carregada, e são proteínas que apresentam caráter básico. A porção $\mathrm{N}$-terminal das histonas é denomidado cauda da histona e se projeta para fora do nucleossomo. $\mathrm{O}$ domínio $\mathrm{N}$ - terminal das histonas que constituem o octâmero esta sujeito a modificações químicas, como a acetilação, metilação e fosforilação de alguns de seus resíduos $(38,39,40,41)$.

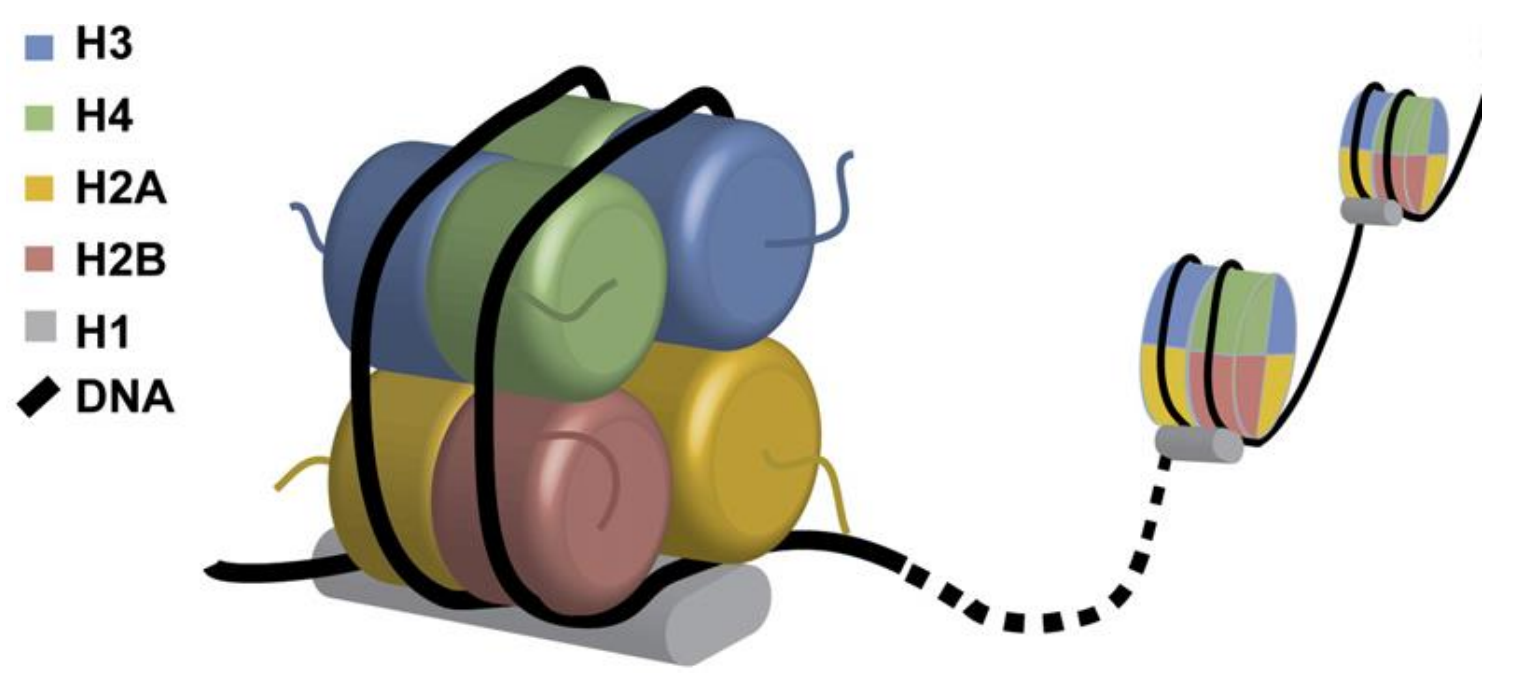

Figura 3 - Modelo esquemático da organização estrutural do nucleossomo. As proteínas histonas sao representadas POR H3, H4, H2A, H2B e H1. Em preto, temse o DNA. Adaptado de: Histone modifications and chromatin remodeling during bacterial infections (41). 
As modificações herdáveis durante a divisão celular que não implicam em mudança na sequência primaria do DNA dá-se o nome de epigenética. A epigenética envolve mecanismos que atuam na acessibilidade da cromatina por meio de modificações estruturais do DNA e modificações ou rearranjos dos nucleossomos $(41,42,43)$. Esses mecanismos são essenciais para os processos de diferenciação e memória celulares (43). Consequentemente a regulação epigenética é essencial para manter o perfil de expressão gênica nos diversos tipos celulares e entendimento dos mecanismos básicos que mediam essa regulação é fundamental para compreensão dos processos de diferenciação e programação genômica (42).

Tabela 9 - Modificaçoes pós traducionais das caudas das histonas.

\begin{tabular}{|c|c|}
\hline Acetilação & $\mathrm{k}-\mathrm{ac}$ \\
\hline Metilação (lisina) & Kel-mel 1, K-mel2, K-mel3 \\
\hline Metilação (arginina) & r-mel1, r-me2s, r-me3a \\
\hline Fosforilação (serina e treonina) & $\mathrm{S}-\mathrm{PH}, \mathrm{T}-\mathrm{PH}$ \\
\hline Fosforilação (tirosina) & $y-p h$ \\
\hline Ubiquitinação & k-ub \\
\hline Sumoilação & $\mathrm{k}-\mathrm{su}$ \\
\hline Ribosilação & ADP-Ear \\
\hline Deiminação & R cit \\
\hline Isomeração de prolina & P-cis $P$ trans \\
\hline Crotonilação & $\mathrm{k}-\mathrm{cr}$ \\
\hline Propionilação & k-pr \\
\hline Buirilação & k-bu \\
\hline Formilação & $k-f o$ \\
\hline Hidroxilaçao & $y$-oh \\
\hline 0-glicosilação & s-glcNAc; T-GlcNAc \\
\hline
\end{tabular}

Adaptado de: Cancer epigenetics: from Mechanism to therapy (44) legenda: me1 monometilação; m2 dimetilação; me3 trimetilação; me2s dimetilação simétrica; me2a dimetilação assimétrica; cit citrulina.

Atualmente, sabe-se que as alterações pós traducionais nas porções $\mathrm{N}$-terminais das caudas das histonas resultam em modificações complexas, alterando as 
interações não covalentes dentro e entre os nucleossomos. A estrutura da cromatina é afetada com essas alterações, o que pode gerar como resultado a ativação ou repressão da transcrição gênica em determinada região do genoma, tudo isso através da exposição ou ocultação dos locais da ancoragem da maquinaria de transcrição ou da modificação dos locais de reconhecimento pela mesma maquinaria. Esta regulação epigenética é dependente do tipo de modificação química, do nível desta modificação e do sítio da histona onde ocorrera a modificação. Esta regulação, portanto, é conhecida como "código das histonas" (39).

Alterações genéticas e epigenéticas podem desencadear o aparecimento de funções gênicas aberrantes e mudança na expressão gênica e estabilidade do genoma, características principais do câncer $(44,45)$. O conjunto de modificações epigenéticas é denomidado "epigenoma" e prevê um mecanismo para diversidade celular, regulando a informação genética que pode ser acessada pela maquinaria celular $(46,47)$.

Em contraste com ocorrências genéticas, as alterações epigenéticas na cromatina são bioquimicamente reversíveis. Em face de diversos estímulos, mecanismos epigenéticos podem ser alterados, sendo observados como uma capacidade flexível e adaptativa do genoma $(48,49)$. Por serem reversíveis, alterações epigenéticas são um potencial alvo terapêutico de silenciamento, com possibilidade de reversão do dano pós traducional $(50,51)$.

As informações transmitidas através das modificações epigenéticas podem apresentar papel crítico na regulação de processos que envolvem o DNA, tais como reparo, replicação e transcrição. Assim sendo, padrões de expressão anormais ou alterações genômicas em reguladores da cromatina podem desencadear resultados profundos e levar a indução e manutenção de vários tipos canceres $(51,52,53)$. 


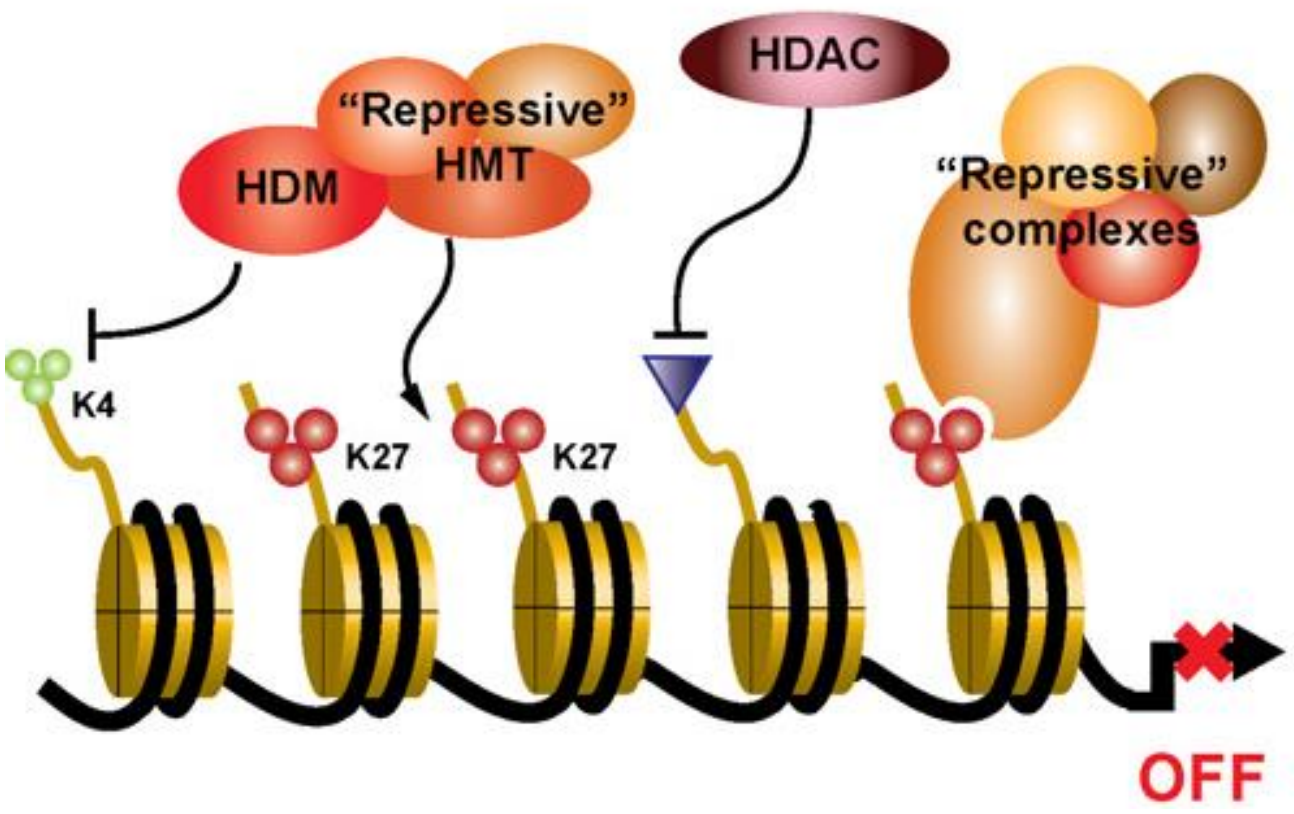

Figura 4-A Desregulação de genes supressores tumorais por metiltransferase de histona. HMT: methyltransferasehistona; HDM: demethylasehistona; HAT: acetyltransferasehistona; HDAC: histona-desacetilase. (53).

\subsection{METILTRANSFERASES DE HISTONA}

A modificação pós-tradução das histonas por metilação são catalisadas por enzimas chamadas Metiltransferases histona (HMTase). Estas são capazes de influenciar processos biológicos, incluindo o desenvolvimento normal, o crescimento celular e a regulação da transcrição genética. Recentemente, as associações entre os vários tipos de câncer e a regulação alterada de enzimas modificadoras dehistona foram descritos (53). Desequilíbrios nas vias de metilação de histonas podem afetar muitos processos regulados pela cromatina, entre os quais a regulação da transcrição, reparo do DNA e estabilidade cromossômica são os mais relevantes para a tumorogênese. Neste contexto, ao lado de mutações genéticas, a epigenética também parece desempenhar um papel importante nas neoplasias hematológicas (54).

Resumidamente, na porção $\mathrm{N}$-terminal das histonas ocorre a metilação de resíduos básicos como lisinas $(K)$, argininas $(R)$ e histidinas $(H)$. As lisinas podem ser 
monometiladas (Kme1), dimetiladas (Kme2) ou trimetiladas (Kme3), enquanto as argininas podem ser monometiladas (Rme1), simetricamente dimetladas (Rme2s) ou assimetricamente dimetiladas (Rme2a). A metilação de histidinas é aparentemente rara e ainda não foi totalmente caracterizada, mas já foi reportado que este aminoácido pode ser monometialdo (Hme1) $(55,56)$. Os diferentes níveis e complexidades das metilações, fornecem as metiltransferases um potencial regulatório de grande importância uma vez que cada evento tem um efeito especifico na estrutura da cromatina e na interação de proteínas regulatórias com a cromatina $(57,58)$. A adição de grupos de metil $(\mathrm{CH} 3)$ no carbono 5 de Citosina seguida por Guanina (dinucleotídeo $\mathrm{CpG}$ ) nashistonas é catalisada por enzimas denominadas metiltransferases de histonas (histone methyltransferase - HMTase, em inglês). Esta reação catalítica é realizada através da transferência de grupos metil advindos de doadores s-adenosilmetionina (SAM). É possível dividir as HMTases em três grandes grupos: 1) proteínas que possuem o domínio SET e 2) proteínas DOT-like, ambas metilando resíduos de lisina; e 3) família de metiltransferase de arginina (arginine Nmethyltransferase- PRMT, em inglês) $(57,58,59)$.

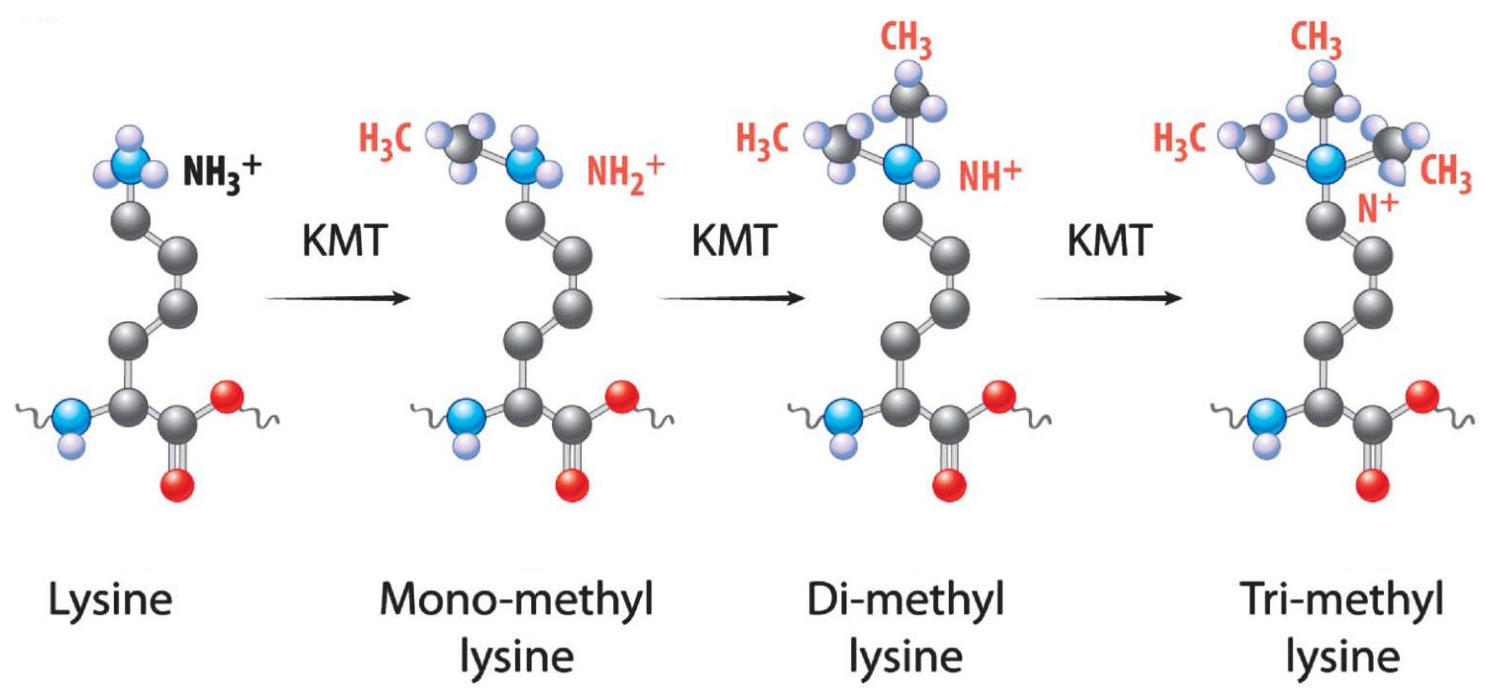

Figura 5: Diversidade de estados químicos obtidos pela metilação sequencial de resíduos de lisina catalisada por diversas famílias de metiltransferases de lisina. Adaptado deCopeland et al. (2013) (60)

De maneira geral, a metilação da lisina 4 histona H3 (H3K4me), H3k36me e H3K79me está relacionada com a ativação gênica, enquanto a di- e trimetilação em H3K9, H3K27 e H4K20 estão relacionadas ao silenciamento gênico (64). Além do 
processo de expressão genica, a metilação de resíduos de lisina também foi associada a processos relacionados a cromatina, como replicação, recombinação e reparo do DNA $(59,60)$.

Existem fortes evidências de que as modificações de histona são herdadas durante as divisões celulares, porém essa transmissão é muito mais complexa que a vista para a metilação do DNA, principalmente devido à replicação independente das moléculas de histonas. Existem evidências que grupos protéicos importantes para a transmissão de estados de cromatina silenciada (grupo Polycomb) ou ativa (grupo Trithorax) durante o desenvolvimento estejam relacionados, por exemplo, com a manutenção das modificações em H3K27 e H3K4, porém pouco se sabe dos mecanismos de heranças das modificações de histona $(60,61,62,63)$.As marcas epigenéticas, tanto metilação do DNA quanto modificações de histona, atuam simultaneamente para regular a transcrição gênica em um processo complexo.

Assim, muitas pesquisas mostram evidencias que sugerem associação entre carcionogênese e metilação aberrante de histonas $(53,62)$. Estudos pioneiros mostraram que mudanças gerais nos níveis de metilação das histonas estão relacionadas com aumento da recorrência de câncer e com baixa sobrevida dos pacientes (64).

Sendo o câncer uma doença genética e epigenética, têm sido descritas alterações epigenéticas em praticamente todos os tipos tumorais, entre eles, câncer de colon, endométrio, hepáticos, do sistema nervoso, de mama, esôfago, bexiga, de pele, leucemias, etc. $(64,65)$. As modificações de histona também já foram descritas como alteradas em processos tumorais, inclusive relacionadas com parâmetros clínicos da doença, como fatores prognósticos e recorrência (66).

As alterações em proteínas não histonas que reconhecem marcações epigenéticas, essencial para o correto funcionamento dessas, também já foram descritas, como é o caso da diminuição do nível da proteína $H P 1$, que reconhece a metilação em H3K9, e está associado com a progressão tumoral (67).

As ilhas CpGs, geralmente hipermetiladas em células cancerígenas, têm sido associadas com modificações de histona específicas, como: deacetilação de $\mathrm{H} 3$ e H4, perda da trimetilação de H3K4 e ganho de metilação em H3K9 e trimetilação de H3K27 
(67). Pouco se sabe do perfil de modificações de histona global, tanto em células normais, quanto em tumorais, porém a análise do perfil de $\mathrm{H} 4$ revelou evidências de que, em células tumorais, há perda de monoacetilação em K16 e a trimetilação em K20, correspondentemente com as áreas de hipometilação de DNA (68). O aumento de expressão da enzima HDAC foram verificados em diversos tipos tumorais compatível com a perda de acetilação verificada $(70,71,72)$.Inicialmente as evidências que ligavam a metilação aberrante de histonas ao câncer selimitavam a correlação de determinados perfis às alterações de expressão de genes sabidamente envolvidos na carcinogênese(73). Kondo et al. (74), por exemplo, demonstraram que a redução dos níveis de metilação de H3K4 e o aumento da metilação de H3K9, em conjunto com a metilação do DNA na região promotora, estão associados com o silenciamento dos genesMLH1em câncer gastrointestinal (74). Posteriormente, o nível global de metilação de lisinas foi relacionado também a uma maior taxa de recorrência e óbito em determinados tipos de neoplasias. Park et al. (75) demonstraram, através de estudo de imunohistoquímica, que o aumento dos níveis globais de trimetilação da lisina 9 da histona H3 (H3K9me3) se correlacionava com pior prognóstico em adenocarcinoma gástrico. Barlesi et al. (76) verificaram, através de estratégia similar ao estudo anteriormente citado, que, em adenocarcinoma não-pequenas células de pulmão, a redução dos níveis globais de H3K4me2 parece estar relacionada com pior prognóstico da doença.

Outro achado verificado em células cancerígenas é a perda global dos marcadores H3K4me3 (ativação gênica), H4K20me3 (repressão) e ganho global dos marcadores repressivos H3K9me e H3K27me3 (76). Além disso, observou-se que a desregulação da atividade das próprias metiltransferasesde histonas também estava associada a maior agressividade de determinados tipos de câncerese, em alguns casos, podia também estar relacionada ao próprio processo carcinogênico (76). Um dos trabalhos pioneiros nessa área foi publicado por Hamamoto et al $(77,78)$, onde descreveram que o gene SMYD3 estava altamente expresso em células tumorais,em comparação com as normais e, além disso, tinha função crítica na proliferação de linhagensde carcinoma hepatocelular e colorretal.

Bracken et al. (79) mostraram que o gene $E Z H 2$, uma metiltransferase que contémdomínio SET, é altamente expressa em vários tipos de tumores humanos e é essencial para aproliferação de células humanas transformadas e não- 
transformadas.Em adição, foi demonstrado que, além da influência na carcinogênese através de suaação de modificação pós-traducional em histonas, algumas metiltransferases protéicas tambémexercem o mesmo papel em nível de proteínas não histonas. Saddic et al. (80) demonstraram que a proteína do gene $R B$ (Retinoblastoma) podeser metilada por SMYD2 na lisina 860 e que essa modificação é capaz de reprimi-lafuncionalmente.

Sabe-se que muitas HMTases que metilam lisinas possuem um domínio denominado SET, que está relacionado a função metiltransferase de histona. Porém, foi demonstrado que, embora algumas proteínas contenham o domínio SET, elas também podem modificar proteínas não histonas. Como exemplo, tem-se a metiltransferase SETD7, capaz de exercer metilação em proteínas como p53 e TAF10 (TATA binding protein associated fator), dentre outras(53).

Com o atual conhecimento sobre quais são os substratos associados ou não a cromatina tem-se um importante desafio pela frente: compreender os mecanismos pelos quais essas enzimas executam suas funções biológicas .

\subsection{MECANISMOS EPIGENÉTICOS ENVOLVIDOS NAS NEOPLASIAS LINFÓIDES}

Nos últimos anos muito interesse tem sido reportado na contribuição epigenética para desenvolvimento e progressão das neoplasias linfoides, incluindo a LLC. A metilação do DNA é parte da programação epigenética que é necessária ao desenvolvimento normal das células $B$. Para entender como os fenomenos aberrantes de metilação contribuem para leucemogênese é importante compreender os padrões de metilação em células B normais. Deaton e colaboradores (81) mostraram que não só regiões metiladas diferencialmente (DMRS) em torno de sítios de inicio da transcrição são importantes, mas também padrões de metilação em células e tecidos especificos. A dinâmica natural da metilação durante 0 desenvolvimento hematopoiético foi estudado por $\mathrm{Ji}$ et al. (82) em progenitores multipotentes de murinos examinando 4,6 milhões de CpGs no genoma. Este estudo demonstrou que a linhagem linfóide requer maiores metilações do DNA que as linhagens mielóides. 
Challen e colaboradores (83) demonstraram que a expressão de DNMT3 em células murinas é superior nas células-tronco hematopoiéticas do que nas células diferenciadas e que a perda de DNMT3a resultou em significativa expansão de células tronco hematopoéticas devido à sua reduzida capacidade de diferenciação, efeito este associado com distribuição de CpG metilados.

Shaknovich e colaboradores (84) evidenciaram mudanças no epigenoma das células $B$ durante passagem pelo centro germinativo $(C G)$ e revelaram que a transição de células $B$ naive $(B N)$ para centroblastos $(C B)$ está associada com a perda da metilação em 235 genes diferencialmente metilados, afetando as vias do NF-kB. Esses achados definiram o cenário para interpretação de mudanças epigenéticas na biologia dos linfomas pré e pós centro germinativo.

Os principais fatores responsáveis pela metilação do DNA são membros da família da DNA metiltransferase (DNMT): DNMT1, DNMT3a, e DNMT3B. Eles possuem padrões de expressão diferentes nas células $B$ periféricas e nas células no centro germinativo (83). As DNMTs são altamente compartimentalizada dentro do GC, com DNMT1 e DNMT3B sendo o mais altamente expresso nas células $B$ de $C G$ do que nas células $B$ naive. $O$ importante papel do DNMTs em linfomagênese é ressaltada pela evidência de Amara e colaboradores (85) que DNMT1, DNMT3a e DNMT3B são superexpressas em $48 \%, 13 \%, 45 \%$, respectivamente, nos linfomas difusos de grandes celulas B(LDGCB) e estão correlacionados com estágios clínicos avançados. Além desses achados, os autores notaram que a expressão concomitante de DNMT1 e DNMT3B esteve correlacionada com a resistência ao tratamento e que a superexpressão da $D N M T 3 B$ foi correlacionada curta sobrevida global.

As metiltransferases DNA identificadas em pacientes com LLC são de expressão variável podendo estar associadas com taxa proliferativa ou momento que as células permanecem na fase $S$ do ciclo celular (86). Amara et al (2013), descreveram que as metiltransferases DNA expressas em portadores de LLC foram as metiltransferases tipo I e IIla. As metiltransferases DNA tipo IIlb apareceram downregulation em células de LLC quando comparadas com linfócitos B normais (85).

Vários pesquisadores evidenciaram que a expressão da ZAP-70 é silenciada pela metilação do DNA. Pacientes com expressão da ZAP-70 silenciada pela metilação do DNA apresentavam uma mediana de sobrevida prolongada (87). 

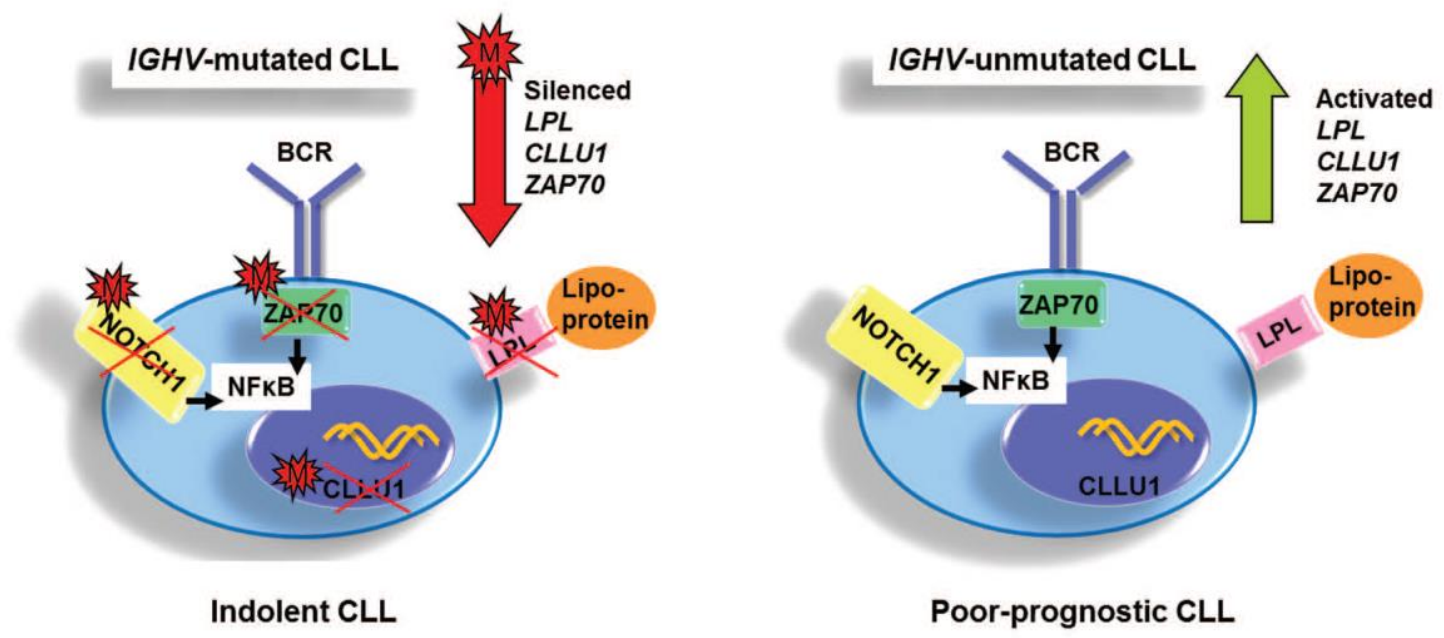

Figura 6-llustração resumindo o estado de metilação diferencial de genes prognósticos-chave, ou seja, LPL, CLLU1 e ZAP-70, e seus efeitos biológicos na LLC (Adaptado de CAHIL et al, 2013) (88).

Vários investigadores têm dado atenção para identificar genes metilantes e sua correlação com deleções cromossômicas ou duplicação nas células de LLC e assim tentar estabelecer impactos na sobrevida. MABUCHI e colaboradores (89) mapearam 3 novos genes CLLD6, CLLD7, CLLD8 na região deletada do cromossomo 13q em células de LLC (89). O CLLD8 apresentou uma alta homologia com SETD1B e parecer ser importante para ligação com MeCP2 (uma proteína de ligação metilante que age como repressor transcricional). Assim, a CLLD8 foi caracterizada como apresentando uma potencial atividade de metiltransferase $\mathrm{N}$ lisina histona.

A leucemia linfocítica crônica (LLC) apresenta perda global da metilação do genoma e aquisição de metilação em sitios especificos. A hipometilação do genoma foi demonstrado usando uma variedade de técnicas de alto desempenho da cromatografia líquida. Esses genes hipermetilados aberrantes na LLC servem como biomarcadores no entendimento da biologia da doença, onde incluem-se: CDKN2A e CDKN2B, ZAP70, DAPK1, eID4.Outro acontecimento significativo na epigenéticada LLCé o silenciamento de inibidores da via WNT, tais como os genes CDH1, DKK1,DKK2, DKK3, SFRP1, SFRP2, SFRP3, SFRP4, SFRP5 e WIF1. Tal silenciamento conduz à ativação da via e superexpressão dos genes membros da família WNT e seu receptor Frizzled (FZD) $(88,89)$. 


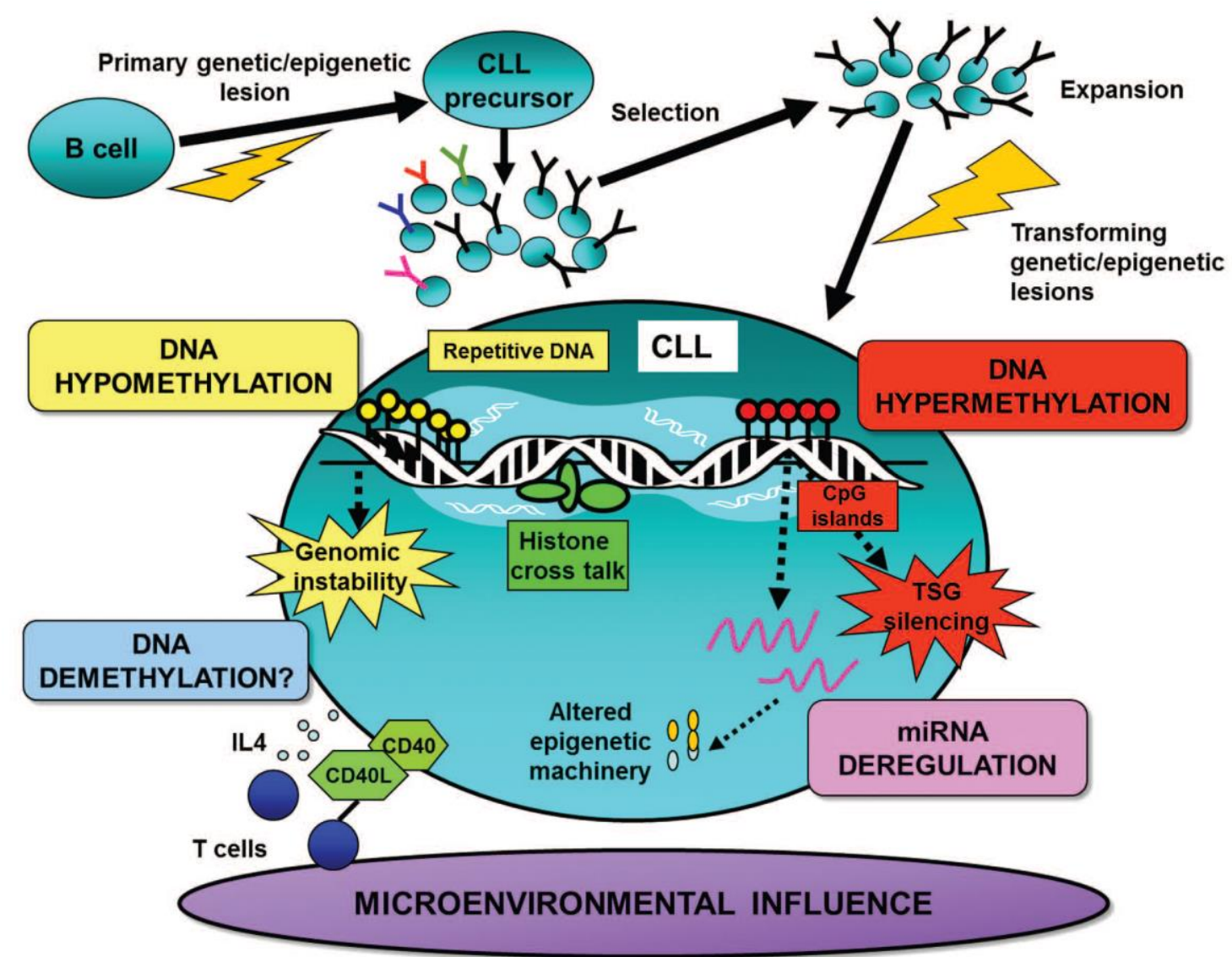

Figura 7- Ilustração defatores epigenéticosque moldam a metilação do DNAemLLC. Detalhes:a hipermetilaçãodo DNA silenciando os genessupressores de tumores(ETG), que conduz ahipometilação de DNAgenômico (adaptado de Cahil et al, 2013)(88).

Como dito anteriromente, além de modificações de histonas, o remodelamento da cromatina também pode epigeneticamente regular a transcrição, replicação e reparo do DNA. Remodeladores de cromatina utilizam a energia a partir da hidrólise do ATP para alterar a localização de nucleossomas ou depositam as variantes de histona, resultando em mudança de conformação e composição da cromatina. As mutações de CHD1 foram identificadas em 4,8\% de LLC. Os genes CHD1 (E-caderinas) pertence à família $C H D$ de remodeladores de cromatina. Os murinos deficientes de CHD1 apresentaram defeitos na diferenciação de eritrócitos e desenvolvimento de linfomas, provavelmente por causa da desregulamentação das células T ativadas (91).

Pouco depois da descoberta de microRNAs humanos (miRNAs), em 2000, surgiram os primeiros estudos da ligação entre os genes miRNA e doenças oncológicas. Constatou-se que miR-15 e miR-16-1 foram frequentemente deletados ou suprimidos em células de LLC. Assim, tornou-se gradualmente claro que a 
expressão do gene aberrante de miRNAs ocorria como resultado de alterações genômicas, assim alguns miRNAs desregulados funcionavam como oncogenes(oncomiRs) ou supressores tumorais e outros miRNAs-chave, com ação anti-apoptótica, são reprimidos ou excluídos em tumores linfóides $(90,91)$. Por exemplo,a deleção do 13q, onde inclui os miR-15a /16-1 atuando como um supressor tumoral, levando a superexpressão do BCL2 e desregulação da apoptose, contribuindo para mecanismo de leucemogênese em celulas murinas. A figura 8 exemplifica as anormalidades epigenéticas que contribuem para transformação das células B normais em neoplasias linfóides maduras.

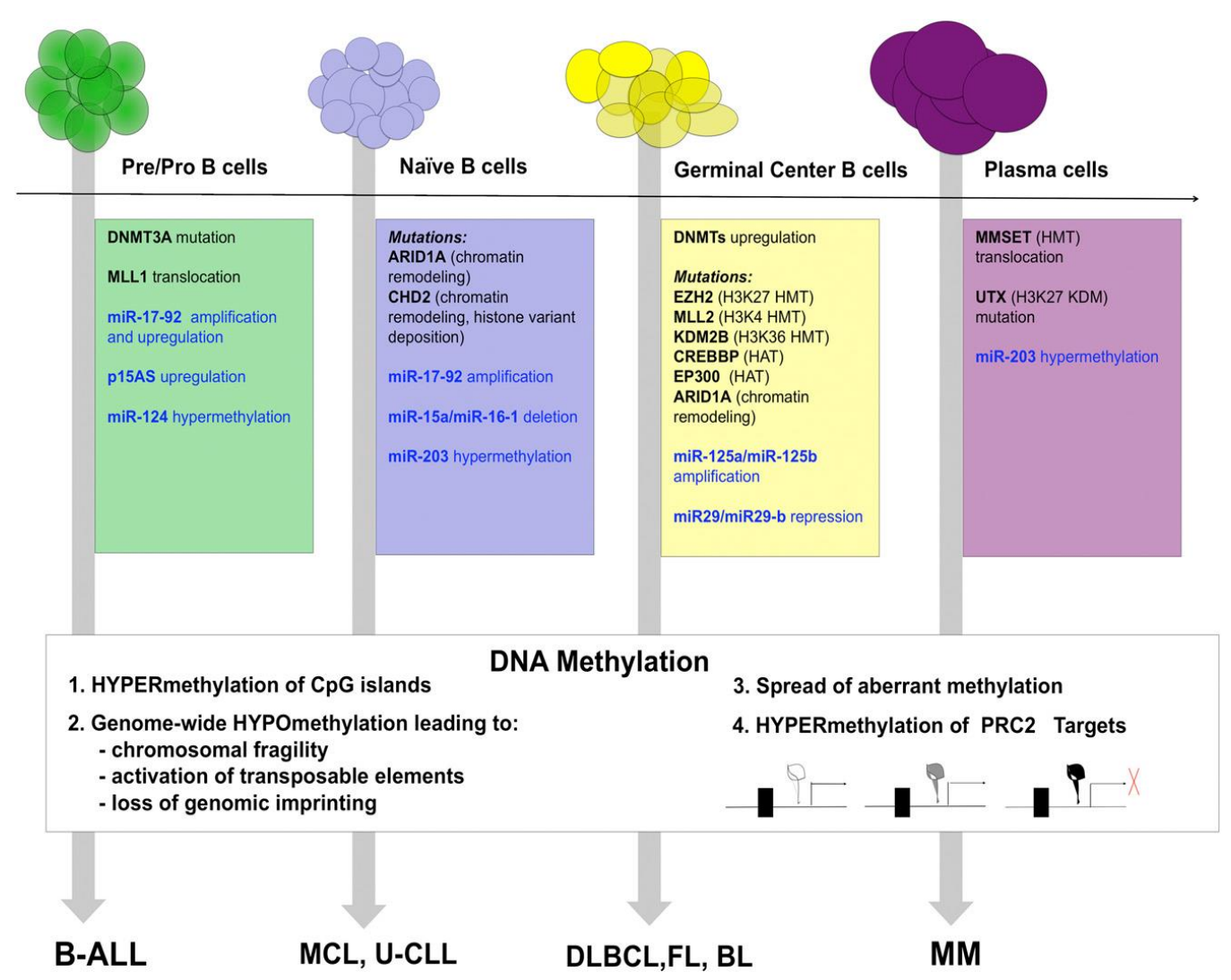

Figura 8- Resumo de anormalidades epigenéticas que contribuem para a transformação neoplásica de precursores de células B normais (no topo) para neoplasias linfoides B maduras. Mudanças de metilação de DNA encontram-se resumidos no quadro branco. (Adaptado de Jiang et al, 2014)(92). 
Assim, a pesquisa de outros mensageiros epigenéticos são cruciais para melhor entendimento da complexa regulação epigenética da LLC, que em última análise, visam a compreensão da biologia da doença e o desenvolvimento de tecnologias terapêuticas com alvo molecular específico.

\subsection{FAMILIA SET}

O domínio SET está presente em famílias de proteínas que metilam resíduos de lisinas em histonas nas células eucariotas. Esta família de proteínas é composta por 130 aminoácidos de cadeia longa. Originalmente este domínio foi identificado como um domínio compartilhado por três proteínas de Drosophila melanogaster envolvida em processos epigenéticos: supressor de variegação (supressor of veriegaton - Su (var)3-9 -, em inglês), potenciador de zeste (enhancer of zeste - E(z) -, em inglês) e tritorax (trithorax, em inglês) - formado com as inicias dessas proteínas o acrônimo SET (92). Esse domínio catalisa a adição de grupos metil a resíduos de aminoácidos principalmente na lisina 4 da histona $3(40,93)$.

A classe de HMTases, SET, que é capaz de mono, di, ou trimetilar resíduos de lisina nas histonas pela utilização do seu substrato S-adenosil-L-metionina (SAM).Inicialmente, sua atividade catalítica era específica para as lisinas, sendo promovida pela presença do domínio conservado SET ( $\underline{S} u(v a r) 3-9$, Enhancer-ofzeste, Irithorax) nessas proteínas. Atualmente, verificou-se que as proteínas contendo domínio SET também agem em substrato não histonas, algumas das quais constituem reguladores de fatores de transcrição, supressores tumorais e vias de sinalização. Além de agir na cromatina quer por via direta metilando as histonas e assim alterando o enovelamento da cromatina para melhorar ou suprimir os cofatores de ligação, as metiltransferases lisinas de histonas (KMT) podem ser alvo para proteínas não histonas $(94,95)$.Um fator importante resultante da alteração nos níveis globais de metilação e acetilação das histonas está relacionado com a biologia de lesões cancerígenas.

Todas as metiltransferases de lisinas de histona (KMTases), com uma exceção, catalizam a transferência do grupo metil através de um domínio conservado de 
aminoácidos denominado SET (suppressor-enhancer of zeste trithorax).Como dito anteriormente, a metilação das lisinas H3K9, H3K24 e H4K20 estão ligadas ao silenciamento gênico enquanto a metilação da H3K4, H3K36 ou H3K79 estão correlacionadas com a transcrição gênica. Neste nível, sabe-se que as modificações covalentes que ocorrem em resíduos de lisinas e/ou argininas das extremidades $\mathrm{N}$ terminal das histonas $\mathrm{H} 3$ e H4 , estão envolvidas diretamente no controle da expressão gênica através do remodelamento da cromatina. No que tange a metilação de histonas, cada um dos seus resíduos de aminoácidos pode receber um ou dois grupamentos metil. No caso de lisinas, é possível, ainda, a adição de um terceiro grupo metil(Figura 9). As modificações podem também ocorrer em um único resíduo das histonas ou simultaneamente em múltiplos aminoácidos. Até 2012, haviam sido descritas 50 proteínascom domínios SET e uma histona metiltransferase DOT1L que não contém o referido domínio(95).

A família SETD - SET domain containing - pertence à família de proteínas que desempenham importante papel no remodelamento da cromatina, metabolismo das histonas e progressão do ciclo celular. No entanto, os passos funcionais do ciclo celular que são regulados por proteínas da família SETD ainda permanecem desconhecidos.As proteínas de domínio SET foram agrupadas em famílias com base na seqüência conservada das regiões descritas do domínio SET e, aparentemente, cada família possui especificidade de ligação ao substrato (ex.SETD1A, SETD1B, SETD2, SETD3, SETD4, SETD5, SETD6, SETD7,SETD8 e SETMAR).Assim, são descritos abaixo uma revisão sumaria dos 10 genes da família SETD(95).

O gene SETD1A - SET domain containing $1 A$ - está localizado no cromossomo16 (16p11.2). Este gene codifica a proteína que faz parte de um complexo de metiltransferase de histona e suas ações enzimáticas sao mono, di e trimetilação da lisina 4 histoma H3 (95). Em estudos prévios, a hiporregulação de 20 genes levou ao quadro de citottoxicidade deste componente nas células. Esta hiporregulação ocorreu por conta dos baixos níveis de metilação da lisina 4 da histona H3 nos loci desses genes, decorrente da hipoexpressao do gene SETD1A $(95,96)$. Assim, temos em SETD1A um possível oncogene, cuja terapia para o câncer pode investir como novo alvo. Não foi relatada, ainda, a relação entre SETD1A e a leucemogênese. 
O gene SETD1B - SET domain containing $1 B$ - está localizado no braço longo do cromossomo 12 (12q24.31). Este gene codifica a proteínas que faz parte de um complexo de metiltransferase histona e sua ação enzimática é a trimetilação da lisina 9 da histona H3 (95). Na carcinogênese de câncer de pulmão foi demonstrado que SETD1B está mais expresso no câncer de pulmão do tipo pequenas células e não pequenas células, tanto em linhagens celulares quanto em amostras de tecidos tumorais (97). Quando células de câncer de pulmão são tratadas com o inibidor global de metilação de histona 3- deazaneplanocin A (DZNep), SETD1B é hiporregulado. Li e colaboradores (98) demonstrou que SETD1B interage diretamente com DNMT3A localizando e direcionado os promotores do silenciamento gênico das células tumorais in vitro (exemplo RASSF1A). Sabe-se que a DZNep degrada a metiltransferase EZH2, cuja atividade é trimetilação da lisina 27 da histona $H 3$, e recentemente foi demonstrado também a degradação da proteína que trimetila a lisina 4 da histona $\mathrm{H} 3$, diretamente relacionada a atividade do gene $\operatorname{SETD1B}(98,99)$. Além disso, foi visto em modelo de melanoma em zebrafish que a metilação da lisina 9 da histona $\mathrm{H} 3$ causada pela hiperespressao do SETD1B acelera de forma significativa a formação do melanoma no zebrafish. Neste modelo, portanto, SETD1B foi estabelecido como um oncogene (100). Não há relatos do envolvimento do SETD1B na LLC.

O gene SETD2 - SET domain containing 2 - está localizado no braço curto do cromossomo 3 (3p21.31) e codifica uma proteína metiltransferase de histona específica para a lisina de posição 36 da histona H3 (H3K36). Essa proteína contém um domínio de ativação transcricional que tem sido achado associado com a hiperfosforilação do RNA polimerase II $(101,102)$. Recentemente SETD2 começou a ser relatada como um suposto supressor de tumor estando significativamente menos expresso em amostras de câncer de mama e em tumores que se encontram em estágios mais avançados (103), além de mutações desse gene terem sidos relacionados ao desenvolvimento do câncer renal pois a inativação da histona SETD2 metiltransferase, localizado em 3p21.31 foi um achado comum em células do câncer renal (104). Não há relatos do envolvimento deste gene com LLC.

O gene SETD3 - SET domain containing 3 está localizado no braço longo do cromossomo 14 (14q32.2) codifica uma proteína homônima que possui atividade metiltransferase. Essa proteína metila as lisinas de posições 4 e 36 da histona H3 (H3K4 e H3K36). Foi indicada uma possível relação entre esta proteína e a morte 
celular por apoptose e regulação no ciclo celular, ja que a sua hiperexpressão diminui a viabilidade celular e ativa a caspase -3 (105). Em 2013, a relação desses genes com a carcinogenese foi estudada e notou-se superexpressão do RNA mensageiro (mRNA) truncado com o domínio SET em linfomas de células $B$, indicando uma possível ação de SETD3 como supressor tumoral $(105,106)$. Não ha relatos de envolvimento da SETD3 em LLC.

O gene SETD4 - SET domain containing 4 está localizado no braço longo do cromossomo 21 (21q22.13). A atividade enzimática codificada por este gene ainda nao foi estabelecida. Porém em 2013, trabalho pioneiro de nosso grupo de pesquisa revelouque este gene se encontra hiperexpresso em amostras clinicas de pacientes com câncer de mama triplo negativo (107). É uma proteína que está alterada no câncer de mama, sendo localizada no citosol e núcleo de células cancerígenas. Está envolvida na regulação da atividade da Ciclina D1 potencialmente afetando o ciclo celular. Não ha relatos de seu envolvimento em LLC.

O gene SETD5 - SET domain containing 5 - está localizado no braço curto do cromossomo 3 (3p25.3)(95,108). A atividade enzimática da proteína codificada por este gene ainda nao foi estabelecida, assim como seu papel na carcinogenese. Nao há relatos do seu envolvimento do SETD5 em LLC. Não há dados que descreva se esta proteína tem importância em processos celulares.

O gene SETD6 - SET domain cointaining 6 - está localizado no braço curto do cromossomo 16 (16q21) e codifica uma proteína que possui atividade metiltransferase específica para lisinas de proteínas (monometilação da lisina 7 em histona H2A variante AZ- H2AZ).Especula-se que este gene esteja envolvido com a diferenciação celular, pois foi demonstrado que a depleção do mesmo gene levou a diferenciação das células tronco embrionárias de camundongos (109).A cascata de metilação de lisina iniciada por SETD6 - que também conta com a EHMT1 - vai atuar para conter a ativação de respostas inflamatórias mediadas por NF-kB em diversos tipos celulares de mamíferos (mediador crítico de transcrição envolvido nos processos de imunidade e inflamação ao câncer)(109).

SETD7- SET domain containing (lysine methyltransferase) 7 - está localizado no braço longo do cromossomo 4 (4q28). Este gene codifica proteína cuja atividade enzimática é amonometilação da lisina 4 da histona H3. Esta enzima possui 
capacidade de metilar substratos não histonas (110). A proteína SETD7 está relacionada com a estabilidade protéica do DNMT. Em células de câncer, a interrupção da atividade de DNMT1 resultou em uma hemi-metilação de um quinto dos sítios CpG no genoma e ativação do checkpoint G2/M, levando a parada do ciclo celular na fase G2. O gene supressor de tumoral p53 é metilado em linhagens celulares de câncer pela SETD7 e por outra metiltransferase, SMYD2. O SETD7 é essencial para a metilação de p53 e é importante para que esta proteína desempenhe sua função em tecidos selvagens em resposta ao dano do DNA. Sugere-se que a perda de SETD7 tem grande significância para a tumorigênese humana (111). Foi revelada a participação de SETD7 na carcinogenese da mama, dado que esta enzima metila diretamente o receptor de estrogênio (112).

O geneSETD8 - SET domain containing (lysine methyltransferase) 8 - está localizado no braço longo do cromossomo 12 (12q24.31). Este gene codifica uma proteína com atividade metiltransferase. Esta proteína é responsável pela monometilação da lisina 20 da histona H4 (H4K20me1). SETD8 é uma proteína que desempenha um papel importante na progressão do ciclo celular e sugere-se que a regulação do SETD8 seja importante para a divisão celular adequada. Sabe-se que o gene SETD8 pode atuar tanto na ativação quanto regressão gênica, apontanto para o seu papel central na modulação da RNA polimerase II $(113,114)$. Foi visto que SETD8 está envolvido no ciclo celular. Tal como acontece com outras enzimas modificadoras de histonas, outros substratos além da $\mathrm{H} 4$, podem ser metilados por SETD8 e podem funcionar nessas vias do ciclo celular (114). Portanto, ainda é necessário continuar identificado esses substratos e avaliar sua metilação mediada por SETD8 no ciclo celular para se proponha a função celular de SETD8(115).

O gene SETMAR (SET domain and mariner transposase fusion gene) está localizado no braço curto do cromossomo 3 (3p26.1). Este gene codifica proteína cuja atividade enzimática de sua porção N-terminal é metilação da lisina 4 da histona H3. Nessa mesma proteína há outra porção fundamental, C-terminal, que contém um domínio transporsase (117). SETMAR foi associado à carcinogenese da leucemia mielóide aguda, por perder o checkpoint de decatenação em células tratadas com inibidores da proteína topo II alfa (responsável direta pelo processo de desemrolamento das cromátides irmãs durante o processo de mitose) como: etoposide, doxorrubicina e mitoxantrona. Assim, as célulasque perdem esse 
checkpoint têm suas cromátides irmãs presas no fuso mitótico, o que pode gerar células com fusões genicas anômalas, deleções, dentre outros efeitos, e que seguem no ciclo celular $(118,119)$. Foi demostrado que no câncer de mama, o silenciamento de SETMAR permite a recuperação da sensibilidade das células tumorais a um quimioterápico cujo principal alvo é a topo II alfa, denominado antraciclina (120), como citado anteriormente. Um estudo dinamarquês evidenciou que em amostras de pacientes com LMA, o SETMAR foi superexpresso nos pacientes sem translocações cromossômicas e com baixo nível de expressão nos pacientes com cariótipo normal, assim inferindo um papel do SETMAR nas aberrações cromossômicas(119). Os autores puderam inferir que os pacientes com superexpressao do SETMAR poderia ter uma resistência aos quimioterápicos inibidores da topoisomerase II, o que já se observa na maioria dos portadores de LMA de cariótipo complexo. Nas amostras de pacientes com LMC e linfoma do manto, o SETMAR não mostrou expressão aberrante $(118,119)$. 


\section{JUSTIFICATIVA}

Estudos moleculares recentes revelaram que a leucemogênese envolve não somente alterações citogenéticas e por mutações, como também desregulações epigenéticas de um número de genes associados ao crescimento, sobrevivência, motilidade celular e diferenciação. Entretanto, os mecanismos moleculares precisos envolvidos na progressão da doença permanecem desconhecidos. Dessa forma, concomitante às análises citogenéticas e de marcadores clássicos da doença, a análise comparativa focada em um grupo específico de genes pode ser de grande valor na determinação de mecanismos que levam a um melhor conhecimento da evolução da doença.

Os avanços no entendimento molecular e epigenético da LLC podem vir a adicionar informações relevantes para a exploração e desenvolvimento de estratégias inovadoras na terapêutica farmacológica, bem como para o diagnóstico e o prognóstico evolutivo desta doença.

As evidências do envolvimento das metiltransferases na proliferação das células tumorais das neoplasias de mama, fígado, rim e colorretal nos levaram a investigar a expressão de outras metiltransferases proteicas na carcinogênese de varias células de linhagens tumorais e de células leucêmicas. O estudo de expressão genica nos possibilita analisar o perfil de diversos genes em uma mesma amostra. Neste sentido a utilização de amostras clínicas para analise de expressão se torna ferramenta imprescindível e preciosa para correlacionar dados moleculares e clínicos.

Deste modo, o presente trabalho pretende analisar e correlacionar a expressão dos 10 genes humanos pertencentes às famílias de HMTase SETD em pacientes portadores de leucemia linfocítica crônica correlacionando com dados clínicos, estadiamento, perfil morfológico, imunofenotípico, citogenético, moleculares e intervenção terapêutica. 


\section{OBJETIVOS}

\subsection{OBJETIVO GERAL}

Este trabalho teve como objetivoaobtenção do perfil de expressão de genes da família SETD codificadores de metiltransferases protéicas em amostras de medula óssea de pacientes portadores de leucemia linfocítica crônica.

\subsection{OBJETIVOS ESPECIFICOS}

- Determinar o perfil de expressão dos 10 genes da família SETD em amostras de pacientes portadores de leucemia linfóide crônica;

- Avaliar as características clinicas, imunofenotípicas, morfológicas, citogenéticas, estadimento e tratamento dos pacientes com leucemia linfocítica crônica a serem incluídos no presente estudo;

- Correlacionar o padrão de expressão dos genes da família SETD nestas amostras com características clinicas, imunofenotípicas, molecularese citogenéticas da leucemia linfocítica crônica;

- Correlacionar o nível de expressão dos genes da família SETD com fatores prognósticos clássicos em leucemia linfocítica crônica seguindo determinação doInternational Working Group of CLL, bem como com a probabilidade de sobrevida global e livre de doença. 


\section{MATERIAIS E MÉTODOS}

\subsection{AVALIAÇÃO DAS CARACTERÍSTICAS CLÍNICAS E PROGNÓSTICAS DAS AMOSTRAS DE PACIENTES PORTADORES DE LEUCEMIA LINFOCÍTICA CRÔNICA.}

Neste estudo, incluímos 59 amostras de pacientes com LLC e 10 amostras de pacientes controles. As amostras são provenientes da parceria com a Faculdade de Medicina da Universidade de São Paulo - Ribeirão Preto (USP-RP). As características dos pacientes tais como idade ao diagnóstico e sexo foram obtidas dos prontuários dos pacientes e a determinação das características clínicas, imunofenotípicas, morfológicas, citogenéticas e de estadiamento da doença foram realizadas nos laboratórios especializados da USP-RP.

Após diagnóstico clínico de LLC, foi estabelecido o perfil imunofenotípico dos linfócitos leucêmicos por meio de análise imunofenotípica (2). Para os controles normais, utilizou-se células mononucleares de sangue periférico (CMSP) a partir de 10 doadores saudáveis pareados por idade (idade 50-84 anos).

Para caracterização dos linfócitos leucêmicos e determinantes prognósticos das amostras de LLC, realizamos as seguintes análises citogenéticas e moleculares:

a) Triagem de células B por imunomagnética: A partir de CMSP isoladas a partir de amostras de doadores saudáveis, realizou-se a separação das células B por triagem magnética (Miltenyi Biotec, Bergisch-Gladbach, Alemanha), de acordo comas recomendaçoes do fabricante. As células de pacientes com LLC e doadores saudáveis foram isoladas utilizando FicollHypaque ${ }^{\circledR}$ de densidade de gradiente(Sigma- Aldrich, StLouis, MO, EUA). As células foram incubadas com um anticorpo anti-humano CD19 anticorpo monoclonal conjugado com micro esferas (Miltenyi Biotec, BergischGladbach, Alemanha). A suspensão de células foi passada através de uma coluna LS(colunas de separação MACSdeMiltenyiBiotec, BergischGladbach, Alemanha) previamente ligado ao dispositivo SuperMACS para selecção de células marcadas. Após o isolamento, a taxa de pureza das amostras foi superior a $90 \%$. 
b) Imunofenotipagem para diagnóstico de LLC:Utilizou-se a citometria de fluxopara a análise com os seguintes anticorpos: anti-CD20 conjugado com FITC, anti-conjugado com PE CD79b, anti-CD19-PE-Cy5 conjugado, a APC conjugada com anti-CD5, FITCconjugatdo, anti- $\lambda$, conjugado com PEanti-K, anti-CD19-PE-Cy5 conjugado, Anti-CD5 conjugado comAPC, policlonalantiFITC $\lambda$, PEpoliclonalanti-k,PE-Cy5 conjugada com anti-CD19 e APCconjugada com anti-CD5. Os anticorpos foram adquiridos da BectonDickinson(San Jose, CA, EUA), exceto 0 anti- $\lambda$ e anti-k policlonal(Dako, Carpinteria, CA, EUA).

c) Avaliação da expressão da ZAP-70: realizou-se calculando a percentagem de células positiva sem comparação como controlo de isotipo (cut off de 20\%), utilizando Pe conjugado anti-ZAP-70 (Dako, Carpinteria, CA, EUA). Um total de 300.000 eventos por tubo foram adquiridos e a estratégia de porta foi realizada como anteriormente descrito para identificar a percentagem de CD19+/CD5+linfócitos B (25).Todas as amostras foram analisadas usando um citometro de fluxo FACSCalibur ${ }^{\circledR}$ (Becton Dickinson, EUA), eo softwareCell Quest $\AA^{\circledR}$ (Becton Dickinson, EUA) foi utilizado para a aquisição e análise de dados.

d) Citogenética clássica (G-bandas): para induzir a metáfase $1 \times 10^{7}$ de CMSP foram cultivadas em meio contendo RPMI 1640 (Invitrogen, Carlsbad, CA, EUA) suplementado com $20 \%$ de soro fetal bovino na presença de interleucina-2 e oligonucleótido CpG-DSP30 (TIBMolBiol, Berlim, Alemanha). Após 72 horas,colcemida (Sigma,Munique,Alemanha) foi adicionada antes da preparação dos cromossomos.O protocolo padrão do laboratório foi seguido para separação cromossômica e a subsequente análise citogenética, sendo que a interpretação foram feitas de acordo com ISCN 2009 (121).

e) Extração de RNA e a síntese de cDNA: O RNA total das amostras leucêmicas e das amostras de controles normais foram isolados utilizando Reagente LS TRIzol® de acordo com o protocolo do fabricante (Invitrogen, Carlsbad, CA, EUA). O DNA complementar de cadeia simples(cDNA) foi gerado a partir de 1ug do RNA total obtido a partir de amostras clínicas e painel comercial de tecidos normais usando o High Capacity cDNA de 
transcrição reversa Kit (Applied Biosystems, Carlsbad, CA, EUA), de acordo com as recomendações do fabricante.

\subsection{ANÁLISE DO PERFIL DE EXPRESSÃO DA FAMÍLIA SETD POR PCR EM TEMPO REAL NAS AMOSTRAS CLÍNICAS DE PACIENTES COM LLC}

Para a análise do perfil de expressão dos genes SETD1A, SETD1B, SEDT2, SETD3, SETD4, SETD5, SETD6, SETD7, SETD8, SETMAR, as amostras clínicas foram submetidas à análise quantitativa de PCR em tempo real (RT-PCR), utilizandose cDNA sintetizado a partir do RNA total extraído de amostras de células $B$ separadas do sangue periférico de pacientes portadores de leucemia linfocítica crônica.

O nível de expressão de cada gene da família SETD nas amostras de pacientes com LLC foi comparado ao de amostras de pelo menos 10 doadores não leucêmicos (controles). $O$ desenho e a contrução dos iniciadores e das sondas para tais genes e para o gene constitutivo $\beta$ actina foram feitos por meio do serviço Assay by Design fornecido pelo fabricante para ensaios com o sistema Taqman $\AA$ (Applied BiosystemsLife Technologies - Carlsbad, CA, EUA) e estão resumidos na tabela 10.Assim, todos as sondas (contendo genes de interesse e $\beta$ acitna) foram testadas pelas diluições: Pool contendo 59 amostras dos pacientes com LLC, diluições 1:2, 1:5, 1:10, 1:20 (contendo RNA das 59 amostras de LLC) e pool contendo as amostras dos 10 doadores e as mesmas diluições citadas anteriormente.

Isso garantiu que todas as amostras dos pacientes e doadores expressavam $\beta$ actina (gene endógeno) e que com diluições não houveram prejuizo de perda ou superexpressão dos genes da familia SETD. 
Tabela 10- . Sondas utilizados para análise da expressão gênica por qPCR.

\begin{tabular}{lc}
\hline Gene & Ensaio \\
\hline SETD1A & Hs00322315_m1 \\
SETD1B & Hs00902716_m1 \\
SETD2 & Hs01014784_m1 \\
SETD3 & Hs01119427_m1 \\
SETD4 & Hs00213731_m1 \\
SETD5 & Hs00216962_m1 \\
SETD6 & Hs00227507_m1 \\
SETD7 & Hs00363902_m1 \\
SETD8 & Hs00360662_s1 \\
SETMAR & Hs00538177_m1 \\
6-actina & Hs99999903_m1 \\
\hline
\end{tabular}

Para uma reação de PCR em tempo real, utilizou-se $2,5 \mu \mathrm{L}$ de água MiliQ, $5 \mu \mathrm{L}$ de Master Mix Universal para TaqMan® (Applied Biosystems Life Technologies CarlsBad, CA, EUA), 0,5 $\mu \mathrm{L}$ do ensaio de iniciadores e sonda (Applied Biosystems Life Technologies - Carlsbad, CA, EUA) e $2 \mu \mathrm{L}$ de amostra de cDNA (em um padrão 1:20 de diluição em água MiliQ, totalizando $10 \mu \mathrm{L}$ de volume final.

As reações foram realizadas em placas de 96 poços (Applied Biosystems - Life Technologies -Carlbad, CA, EUA) em triplicata para cada gene e os ciclos foram determinados automaticamente pelo próprio programa do termociclador StepOnePlus ${ }^{\circledR}$ (Applied Biosystems - Life Technologies -Carlbad, CA, EUA) Holding stage: 2 minutos a $50 \circ \mathrm{C}, 10$ minutos a 95․C; 1 minuto a $60^{\circ}$.C. utilizamos o CDNA das amostras dos 59 pacientes portadores de LLC e dos 10 controles de qPCR, sendo o CT do gene de $\beta$ actina para essas amostas o mesmo (com varição meio 
ciclo para mais ou para menos) em todas as placas. Isso nos garantia o correto funcionamento do ensaio.

Os valores de expressão gênica são expressos com razões entre o gene de interesse e o gene usado como controle endógeno ( $\beta$ actina), que fornece o fator de normalização para a quantidade de RNA isolado a partir de uma amostra e, subsequentemente, calibrada com a valor dos controles (nível de expressão relativa), ou $\Delta \Delta$ Cq. Os ensaios foram testados em diluições seriadas: pool de amostras, diluição 1:2, 1:5, 1:10, 1:20 onde avaliamos se ocorriam diferenças na expressão do cDNA das amostras de LLC comparado com $\beta$ actina, porém não verificamos diferença no padrão de amplificação (Figura 9).

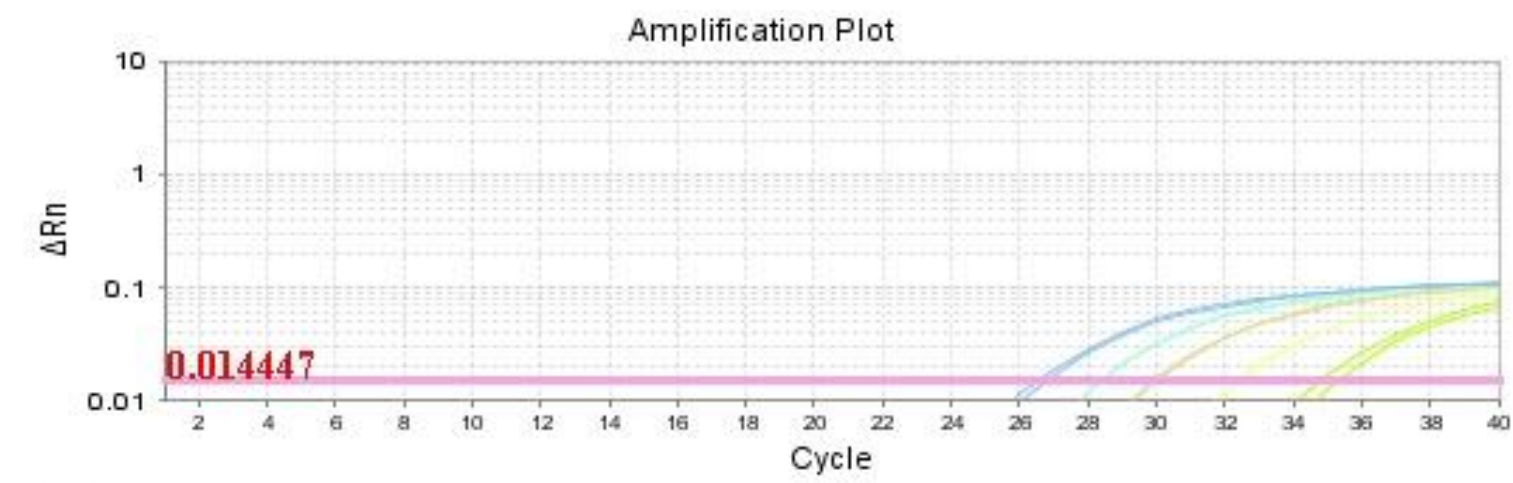

LLC1/20 LLC 1/2 POOL LLC1/10 LLC 1/5

Figura 9- Curva de padronização por qPCR: ensaios para $\beta$ actina com mesmo padrão de diluição citado no texto.

\subsection{ANÁLISE DOS DADOS GERADOS PELO PCR EM TEMPO REAL}

Os dados gerados pelo equipamento foram organizados em uma tabela utilizando o programa Excel (Microsoft) e todos os cálculos para chegar à quantificação relativa pelo método $\triangle \Delta \mathrm{Cq}$ foram baseados no manual do fabricante do equipamento (Applied Biosystems - Life Technologies -Carlbad, CA, EUA, 2008), sendo que o CT (Cycle Thresold) representa o ciclo da reação de PCR em que a amplificação do produto entra na fase exponencial. A média dos valores de todo o CT dos genes da família SETD de cada amostra foi calculada e normalizada por subtração do valor de CT do gene endógeno ( $\beta$ actina) co-amplificado, gerando o valor $\Delta \mathrm{Cq}$ (CT gene de estudo - 
CT gene endógeno). Em seguida, foi calculada a média dos CTs de todas as amostras não tumorais e a média dos CTs do gene endógeno destas mesmas amostras, com cálculo do $\Delta \mathrm{CT}$ das médias. $\mathrm{O} \Delta \mathrm{Cq}$ de cada amostra foi subtraído do $\Delta \mathrm{Cq}$ das médias, gerando o valor do $\Delta \Delta \mathrm{Cq}$. A quantidade de gene alvo, normalizada com uma referência endógena e relativa ao calibrador foi convertida em quantificação relativa (QR) pela fórmula 2- $\Delta \Delta \mathrm{Cq}(122)$.

\subsection{CORRELAÇÃO DO NÍVEL DE EXPRESSÃO DOS GENES DA FAMÍLIA SETD COM FATORES PROGNÓSTICOS CLÁSSICOS DA LLC.}

O resultado da expressão total de cada gene nas amostras de pacientes com LLC foram correlacionados aos fatores prognósticos clássicos da LLC conforme determinação do Grupo Internacional de Estudos de Leucemia Linfocítica Crônica (5).Entre os fatores estão: (1) estadiamento segundo classificação de Binet; (2) contagem de células brancas totais (leucócitos), (3) expressão de ZAP-70, (4) anormalidades cromossômicas, entre as quais as mais frequentes são: deleções de 13q, 11q, 17p e 7q e trissomia do cromossomo 12. A figura 10 demonstra a mediana do Delta $\mathrm{Cq}$ (gene endógeno normalizador $\beta$ actina) de cada gene do estudo. 


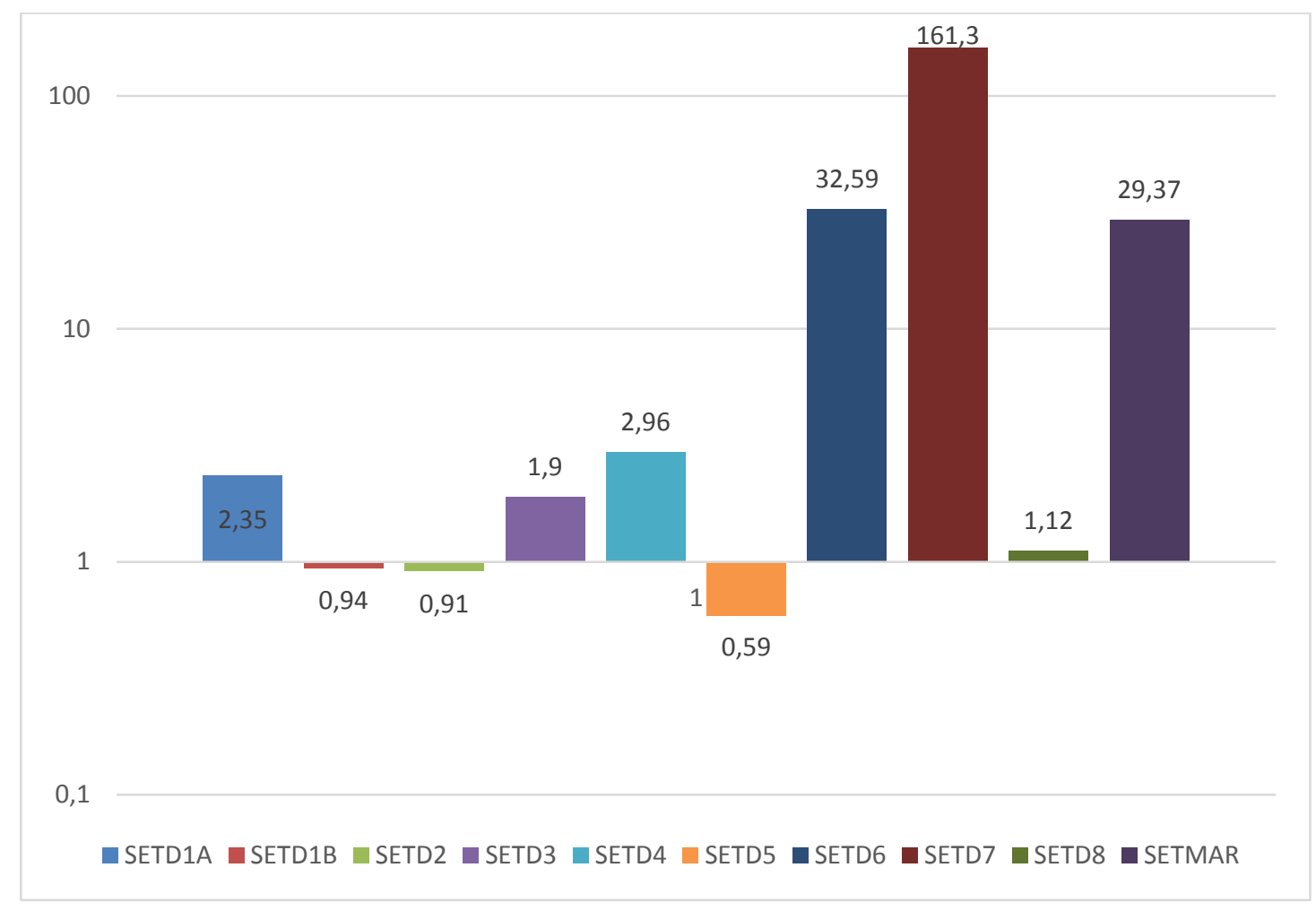

Figura 10- Mediana dos $\triangle \Delta C T$ dos genes da família SETD nas amostras de LLC. Gene endógeno normalizador $\beta$ actina, onde no eixo vertical encontra-se os valores de $\Delta C T$ e no eixo horizontal a descrição do gene correspondente. Todos os genes de interesse do presente estudo se encontram expressos nas amostras de LLC estudadas.

Baseado na distribuição contínuada expressão dos genes da familia SETD em amostrasde LLC, adotou-se o valor médio de expressão de cada gene como o ponto de corte para dicotomizaros pacientes com LLC em "baixa" (reprimido) e "alta" (superexpresso) expressão dos genes: SETD1A, SETD1B, SETD2, SETD3, SETD4, SETD5, SETD6, SETD7, SETD8, SETMAR. 


\subsection{ANÁLISE ESTATÍSTICA}

As informações clínicas e laboratoriais foram comparadas entre os grupos considerados de baixa expressão e de alta expressão. Assim, utilizando o valor da QR final, os gráficos e a análise estatística foram realizados pelo programa GraphPad Prism versão 5. Optamos pelo teste estatísticode Mann-Whitney para amostras independentes, teste de quiquadrado e Fisher para tabelas de contingência e o teste de correlação binária de Spearmann, para análise do padrão de expressão entre os genes da família SETD. A significância estatística foi definida como um valor de p $<0,05$ que representa uma confiabilidade de $95 \%$ da análise.

Os resultados do padrão de expressão dos genes da familia SETD investigados em pacientes portadores de LLC foram analisados com dados de amostras disponíveis em bancos de dados internacionais citados abaixo. Os bancos de genes utilizados para verificação de citação quanto a expressão dos genes da família SETD estão descritos abaixo:
a) www.proteinatlas.org
b) www.cbioportal.org
c) www.oncomine.org
d) www.broadinstitute.org 


\section{RESULTADOS}

\subsection{CARACTERÍSTICAS EPIDEMIOLÓGICAS DOS PACIENTES PORTADORES} DE LLC.

Foram analisadas 59 amostras de sangue periférico de pacientes portadores de LLC e 10 amostras de sangue periférico de controles. Neste grupo as características epidemiológicas foram distribuídas conforme a tabela 12 (abaixo): quanto a distribuição em gênero do sexo masculino 24 casos (40,7\%) e do sexo feminino 35 casos (59,3\%). A mediana de idade ao diagnóstico foi de 63 anos (variando de 32 a 98 anos), sendo idade prevalente na literatura especializada. Quanto ao estádio clínico ao diagnóstico: 39 pacientes (66\%) apresentavam-se no estádio Binet $A, 13$ pacientes em Binet B (22\%) e 7 pacientes em Binet C (12\%). Quanto as alterações citogenéticas mais prevalentes: 5 casos $(8,3 \%)$ com deleção do $13 q$, 4 casos $(6,7 \%)$ com deleção do 17 p, 16 casos (26,7\%) com trissomia 12 e 15 casos (25\%) com cariótipo normal. Quanto a expressão nas células de LLC do ZAP-70 (considerado por dados da literatura como valores de alta expressão acima de $20 \%), 39$ casos $(67,2 \%)$ apresentavam alta expressão de ZAP-70 e 19 casos (32,8\%) baixa expressão.

As amostras dos controles (amostas de sangue periférico) foram submetidas ao estudo imunfenotipico para descartar sinais de subclones linfóides tumorais e contagem da celularidade pelo hemograma completo. Assim, foram descartados portadores de subclones linfóides e citopenias que pudessem interferir na interpretação genética. 
Tabela 11- Características clínicas e laboratoriais dos pacientes com LLC.

\section{Características}

SEXO

Masculino

Feminino

IDADE

ESTADIO CLÍNICO

Binet A

Binet $B$

Binet $\mathrm{C}$

ANÁLISE CITOGENÉTICA

Deleção $13 q$

Deleção $17 p$

Trissomia 12

Normal

MARCADORES PROGNÓSTICOS

Expressão da ZAP-70

$>20 \%$

$<20 \%$

\section{PACIENTES (\%)}

$24(40,7 \%)$

$35(59,3 \%)$

63 (32-98 anos)

$13(22 \%)$

$7(12 \%)$

$5(8,3 \%)$

$4(6,7 \%)$

$16(26,7 \%)$

$15(25 \%)$

$20(33,3 \%)$

$40(67,2 \%)$

$19(32,8 \%)$

\subsection{EXPRESSÃO GÊNICA DOS COMPONENTES DAS FAMILIAS SETD EM AMOSTRAS DE PACIENTES PORTADORES DE LLC}

Primeiramente, pelo fato de ainda não haver relatos dos genes de interesse deste estudo nas neoplasias linfóide B maduras (em especial LLC), investigamos se todos os genes da família SETD estavam expressos nos 10 controles e nas 59 amostras. Assim, foi realizado PCR em tempo real (RT-PCR) para todos os 10 genes nas amostras citadas. $O$ gene endógeno normalizador foi a $\beta$ actina, sendo avaliado o perfil de expressão de cada gene em comparação com controles e realizamos cálculo da mediana com $\Delta \Delta \mathrm{Cq}$ de todas as amostras do gene estudado, conforme exposto previamente na Figura 10. Assim, a partir dessa mediana, realizamos a subdivisão entre dois grupos de expressão. Observou-se que o padrão de expressão 
de cada gene da família SETD nas amostras patológicas $(n=59)$ possuem dois subgrupos: amostras de pacientes com baixa expressão e os com alta expressão.

\subsection{PERFIL DE EXPRESSÃO GÊNICA DE SETD1A NAS AMOSTRAS DE LLC:}

Analisamos a expressão relativa entre os controles e as amostras de pacientes, onde verificamos o gene SETD1A não apresentou relevância estatística quando comparado as amostras controles (Figura 11).

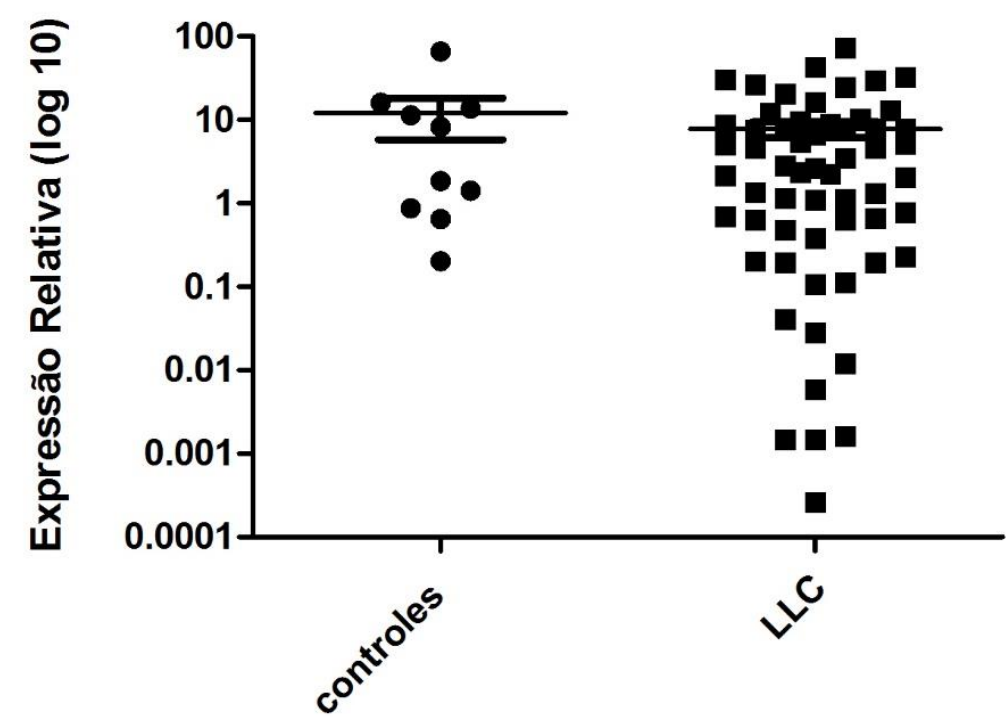

Figura 11. Expressão relativa de SETD1A em amostras de pacientes com LLC. Quantificação Relativa de SETD1A em pool de controles $(n=10)$ e amostras de LLC (n=59), Gene endógeno normalizador = BETA actina. Teste de Mann-Whitney com $\mathrm{p}=0,3196(\mathrm{p}<0.05$ e CI:95\%).

Após a análise entre amostras de LLC e os controles, realizamos o estudo das características clinicas entre os subgrupos de baixa e alta expressão do gene SETD1A de acordo com cutt off =2,35 para este gene. As características prognósticas como contagem leucocitária (Figura 12), contagem de plaquetas (Figura 13), expressão do ZAP-70 (Figura 14)não apresentaram significância estatística. Verificamos relevância estatística quanto ao padrão de expressão do gene e as anormalidades citogenéticas (Figura 15). No grupo de baixa expressão houve um número de casos com anormalidades citogenéticas, podemos sugerir a possibilidade de instabilidade cromossômica nos pacientes do grupo de baixa expressão do gene SETD1A. 0 estadiamento clínico de Binet não demonstrou significância estatística entre os grupos de baixa e alta expressão (Figura 16). 


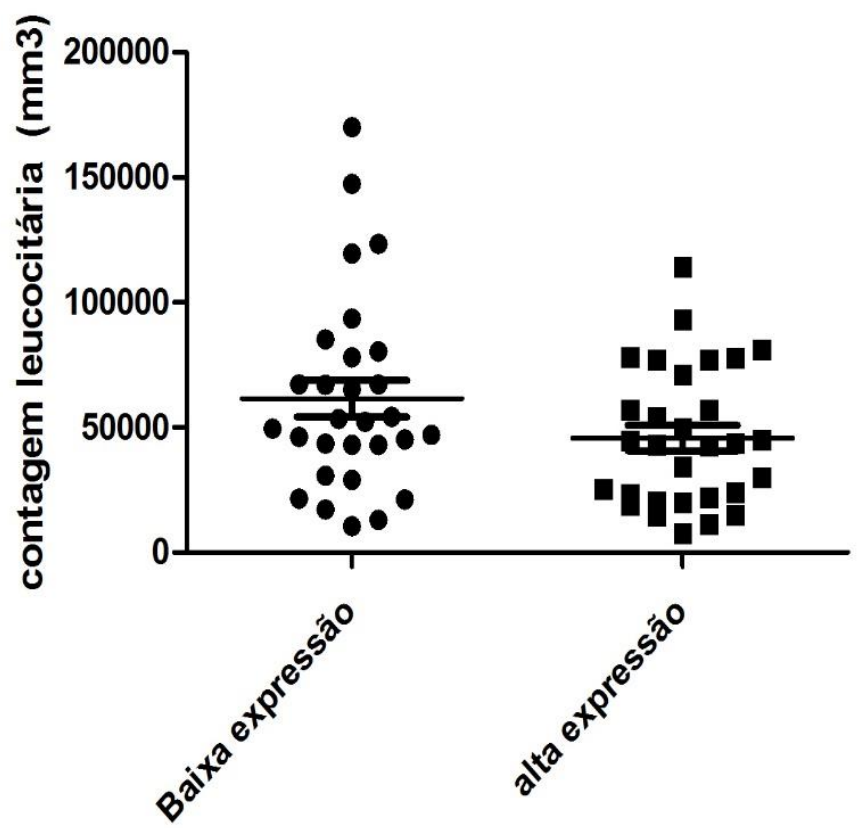

Figura 12. Expressão relativa de SETD1A comparada com contagem leucocitária sendo $\mathrm{p}=\mathbf{0 , 0 6 3 8}$. Teste de Mann Whitney, sendo $\mathrm{p}<0,05$.

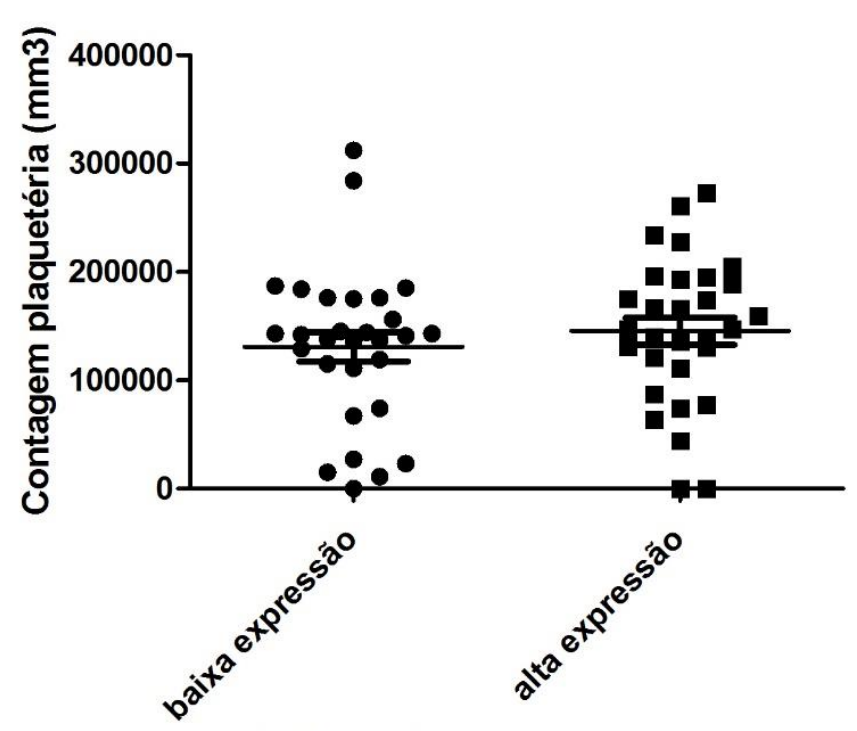

Figura 13. Expressão relativa de SETD1A comparada com contagem de plaquetas, sendo $\mathbf{p}=\mathbf{0 . 1 7 7 5}$ (Teste Mann Whitney com p=0.05). 


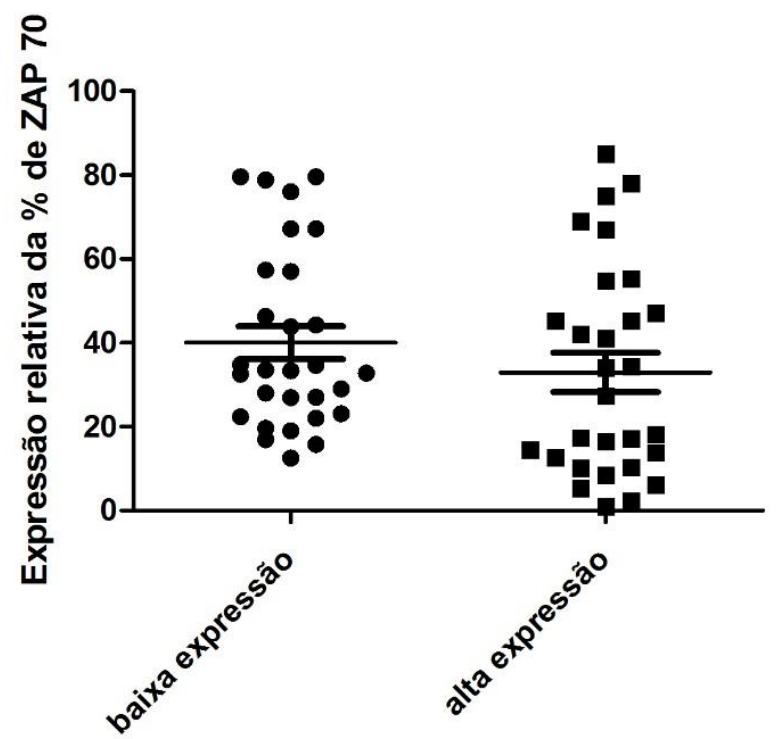

Figura 14. Expressão relativa do gene SETD1A e expressão do ZAP-70 sendo $p=0,0657$ (Teste Mann Whitney, $p<0,05)$.

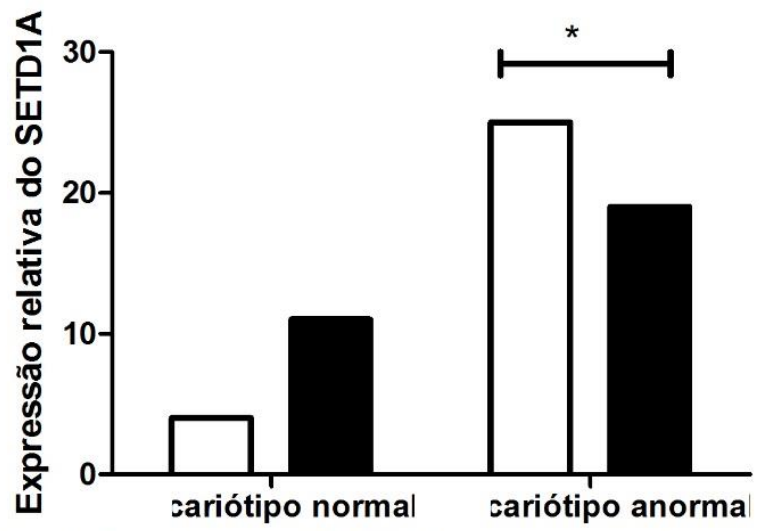

$\square$ baixa expressão

alta expressão

Figura 15. Expressão relativa do gene SETD1A e presença de anormalidades citogenéticas, Figura 15. Expressão relativa do gene SETD1A e presença de
(Teste de Fisher com $p=0,041$ )

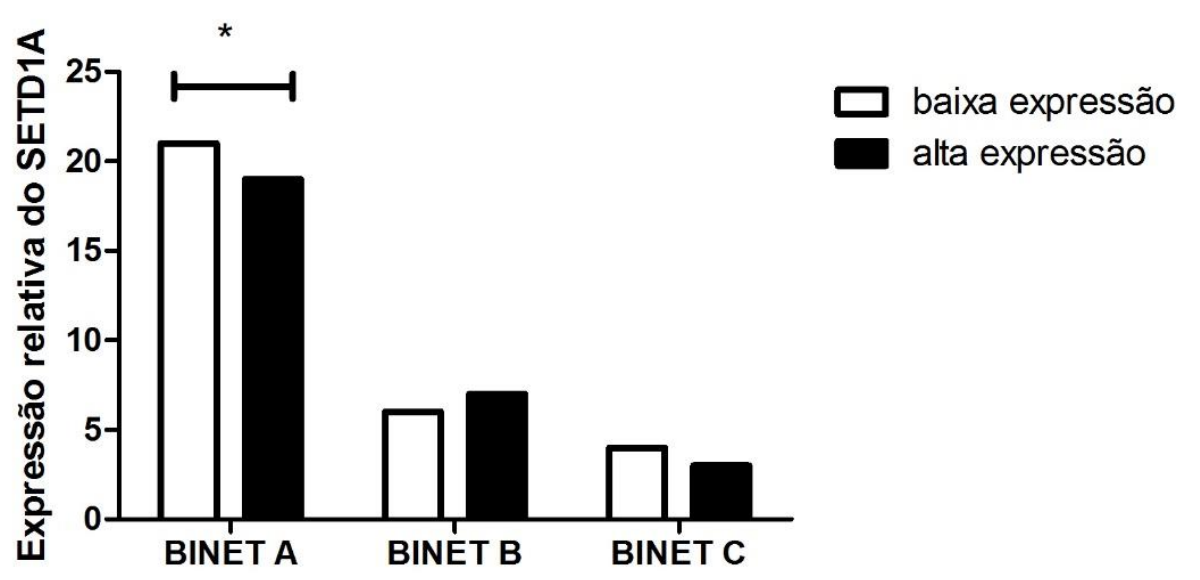

Figura 16. Expressão relativa do gene SETD1A e estadiamento clínico de BINET sendo $p=0,2534$ (Teste Qui-Quadrado, $p<0,05$ ). 
Evidenciamos que os pacientes portadores de LLC com baixa expressão do gene SETD1A apresentaram predominância das anormalidades cromossômicas, sugerindo que a supressão deste gene possa estimular instabilidade cromossômica e assim propiciar proliferação celular. Dentre as anormalidades citogéticas que predominaram no subgrupo de baixa expressão, verificamos a hiperploidia como a anormalidade citogenética mais frequente $(n=8)$. Esta hipótese se faz necessária pois o mesmo grupo de baixa expressão do gene SETD1A apresenta uma contagem leucocitária superior ao grupo de alta expressão do gene, porém sem significância estatística.

Esses dados em LLC divergem com os dados em câncer de mama e câncer colon retal, onde o silenciamento deste gene resultou em desaparecimento da lesão tumoral de células de cancer cólon retal $(123,124)$. Sabe-se que a SETD1A interage $\operatorname{com} \beta$ catenina para ativar um conjunto de genes alvo da via WNT. A não regulação da via de sinalização WNT é frequentemente envolvida na carcinogênese e conduz a cerca de $70-90 \%$ de todo o câncer cólon retal humano $(125,126)$. Em um trabalho recente em modelo murino foi demonstradoque a perda da expressão do gene SETD1A nas células progenitoras hematopoéticas da medula óssea desencadeou uma parada na maturação de células $B$ deste compartimento e maturação de células $B$ de origem esplênica, reduziu assim os níveis de H3K4me3 no locus dos genes de células $\mathrm{B}$ crítica, incluindo $P A X 5$ e RAG1/2 (sendo esses importantes no rearranjo da imunoglubulina de cadeia pesada) $(126,127)$. Lembramos que o gene SETD1A pertence as metiltransferases COMPASS, sendo um dos genes da leucemia de linhagem mista $(M L L)$ que por sua vez está envolvido em numerosas translocações encontrados em várias leucemias agudas humanas (128).

\subsection{PERFIL DE EXPRESSÃO GÊNICA DE SETD1B NAS AMOSTRAS DE LLC.}

Quanto ao padrão de expressão do SETD1B, verificamos que as amostras de LLC apresentaram uma baixa expressão do citado gene quando comparada as amostras controles com $\mathrm{p}=0,1144$ (sendo $\mathrm{p}<0,05$ ) (Figura 17), porém sem significância estatística. 


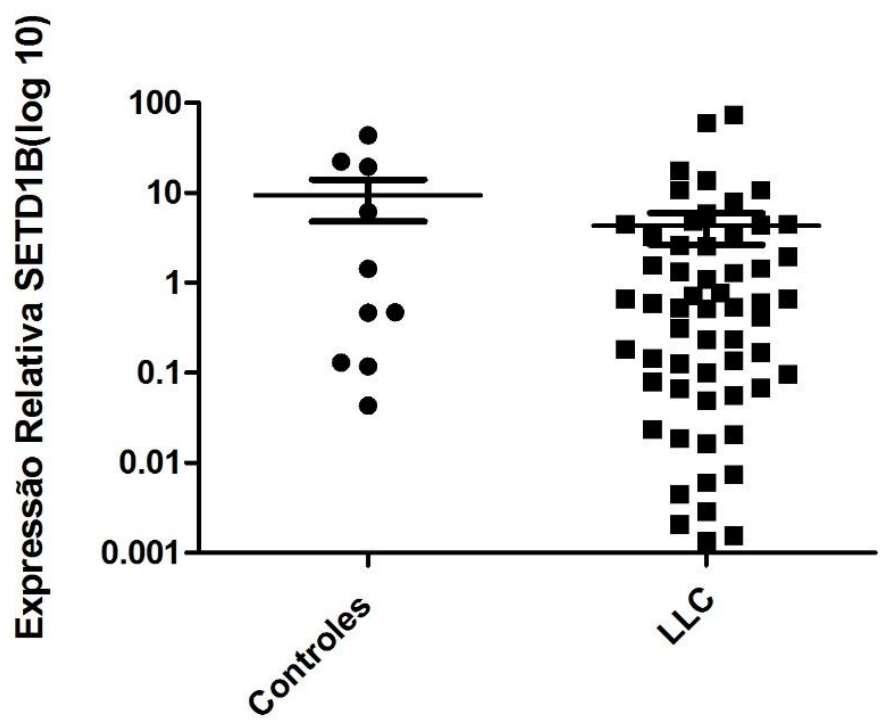

Figura 17. Expressão relativa de SETD1B nas amostras de controles $(n=10)$ e de LLC $(n=59)$, sendo $p=0,1144$ (Teste de Mann Whitney com $p<0.05$ ).

Novamente, os pacientes de LLC foram divididos em dois grupos: baixa e alta expressão, sendo considerado os valores do cutt-off $=0,94$. As demais características clínicas prognósticas na LLC quanto a expressão do gene SETD1B: contagem leucocitária (Figura 18), contagem plaquetária (Figura 19), expressão do ZAP-70 (Figura 20), presença das anormalidades citogenéticas (Figura 21) e estadiamento de BINET (Figura 22) não evidenciaram significado estatístico. Porém, vale ressaltar que os pacientes com baixa expressão apresentaram uma alta contagem leucocitária, semelhante a observada na expressão do SETD1A. 


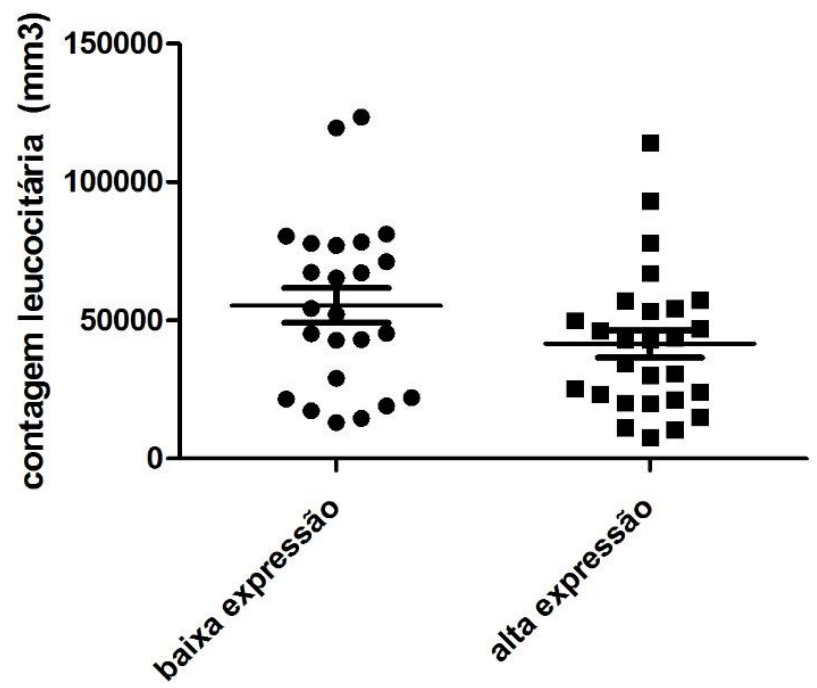

Figura 18. Expressão relativa do gene SETD1B e contagem leucocitária sendo $p=0,543$ (Teste de Mann Whitney, $p<0,05)$.

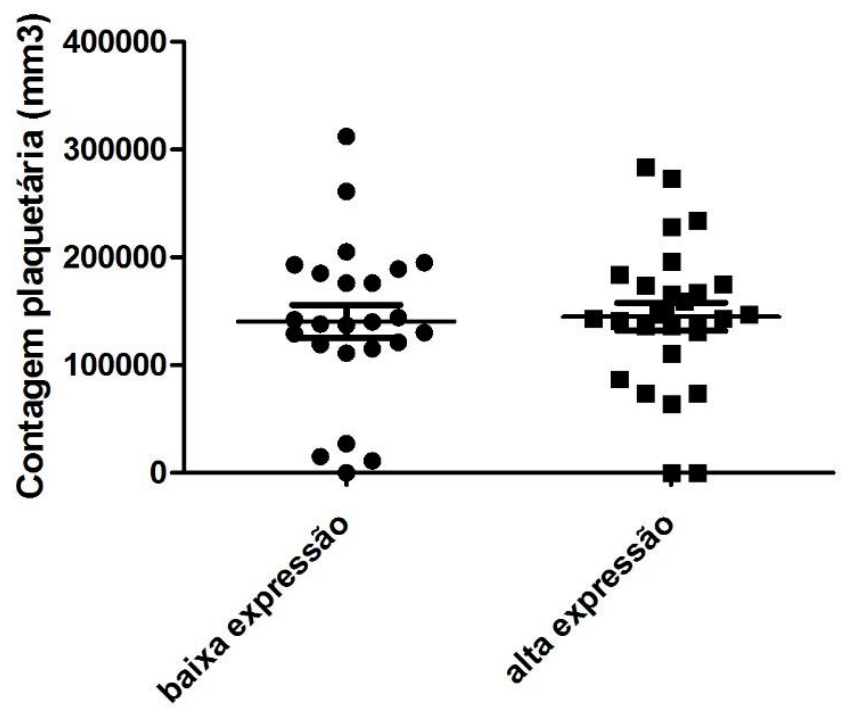

Figura 19. Expressão do gene SETD1B e contagem plaquetária com $p=0,4141$ (Teste Mann Whitney sendo $p=0,05)$. 


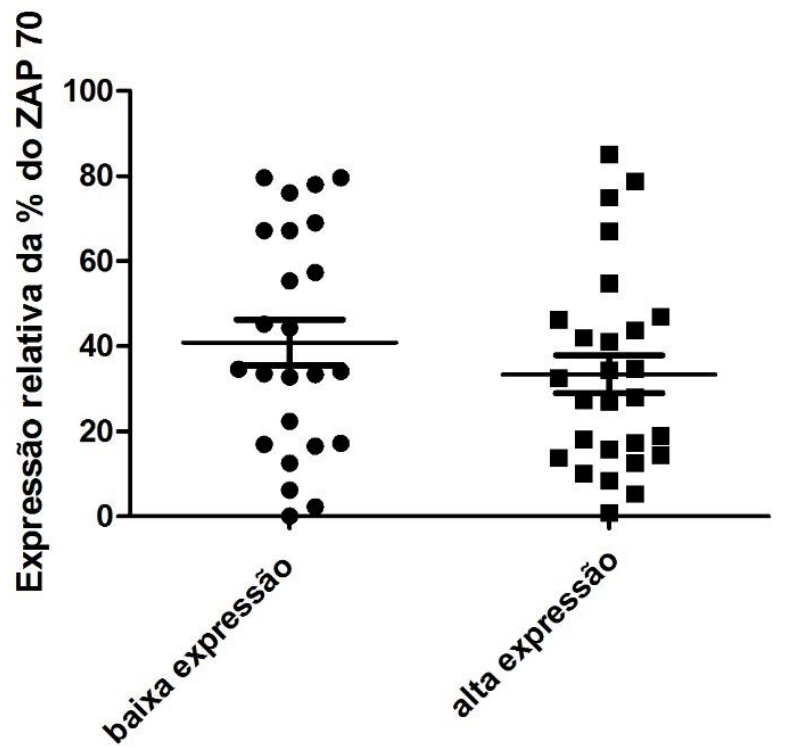

Figura 20. Expressão relativa de ZAP-70 e gene SETD1B com $p=0,1563$ (Teste Mann Whitney sendo $p=0,05)$.

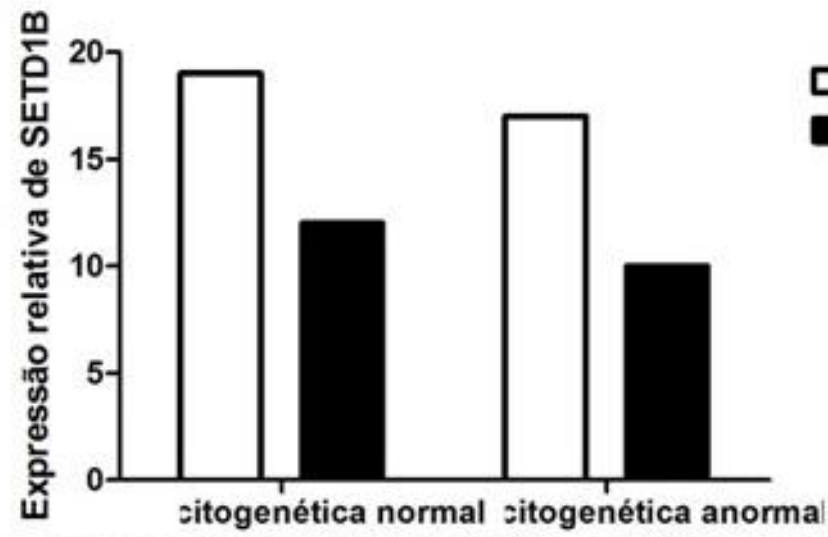

Figura 21. Padrão de expressão do gene SETD1B e cariótipo dos pacientes com $p=0,55$ (Teste de Fisher sendo $p=0,05$ ).

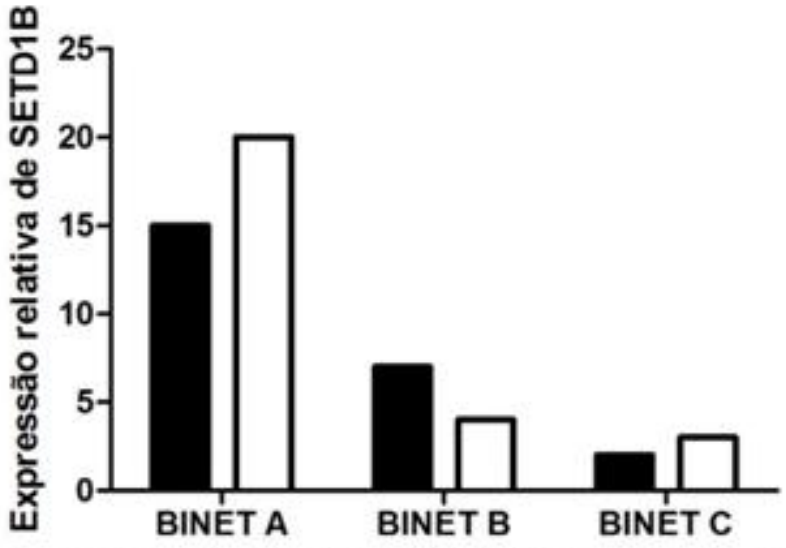

Figura 22. Padrão de expressão do gene SETD1B e estadiamento clínico de BINET com $\mathbf{p}=\mathbf{0 , 6 3}$ (Teste Qui-Quadrado sendo $p<0,05$ ). 
Diante da presença de características semelhantes (como tendência da elevada contagem leucocitária no grupo de baixa expressão) entre a expressão dos dois genes (SETD1A e SETD1B), realizamos a correlação de expressão dos mesmos pelo teste de Spermann. Quando realizamos a correlação de Spearmann verificamos uma fraca correlação no padrão de expressão $(r=0,48)$, onde não conseguimos estabelecer uma associação do padrão de regulação e expressão, isto é, se a dminuição da expressão de SETD1A e SETD1B pode resultar no aumento da leucocitose (massa tumoral) na LLC.

O SETD1B interage diretamente com DNMT3A localizando e direcionando os promotores do silenciamento gênico das células tumorais in vitro (exemplo RASSF1A), estando mais expresso em amostras de câncer de pulmão tipo pequena e não pequenas células. SETD1B interage com RBM15 criando um complexo importante para a regulação epigenética. $R B M 15$ (RNA vinculativo proteína motivo 15) utiliza o mecanismo epigenético de controlar splicing alternativo do MPL (receptor da tromboendopoetina), levando à regulação da resposta da trombopoetina nas célulastronco hematopoéticas (129). Neste estudo, podemos sugerir que a diminuição da expressão do genes SETD1A e SETD1B possam contribuir para instabilidade cromossômica e replicação celular (contagem leucocitária elevada no subgrupo de baixa expressão).

\subsection{PERFIL DE EXPRESSÃO GÊNICA DE SETD2 NAS AMOSTRAS DE LLC.}

A análise de expressão do gene SETD2 demonstrou que os pacientes com LLC possuem diferença na expressão do referido gene quando comparados as amostras controles (Figura 23). 


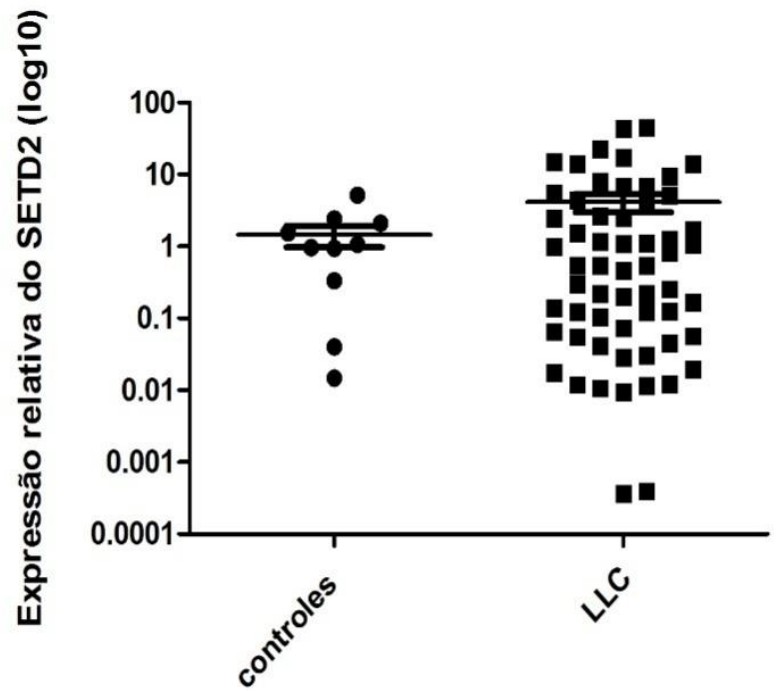

Figura 23. Expressão relativa do gene SETD2 em pacientes com LLC versus controles com $p=0,3698$ (Teste Mann Whitney sendo $p<0,05$ ).

Os pacientes foram subdivididos em dois subgrupos: alta e baixa expressão a partir do cutt off=0,91 (Figura 10). Os pacientes com alta expressão do gene SETD2 apresentaram elevada contagem de leucócitos com significância estatística (Figura 24). Porém, as demais características clínicas não evidenciaram significado estatístico como: contagem plaquetaria (Figura 25), expressão do ZAP-70 (Figura 26), estadiamento de BINET (Figura 27) e presença de anormalidades no cariótipo (Figura 28).

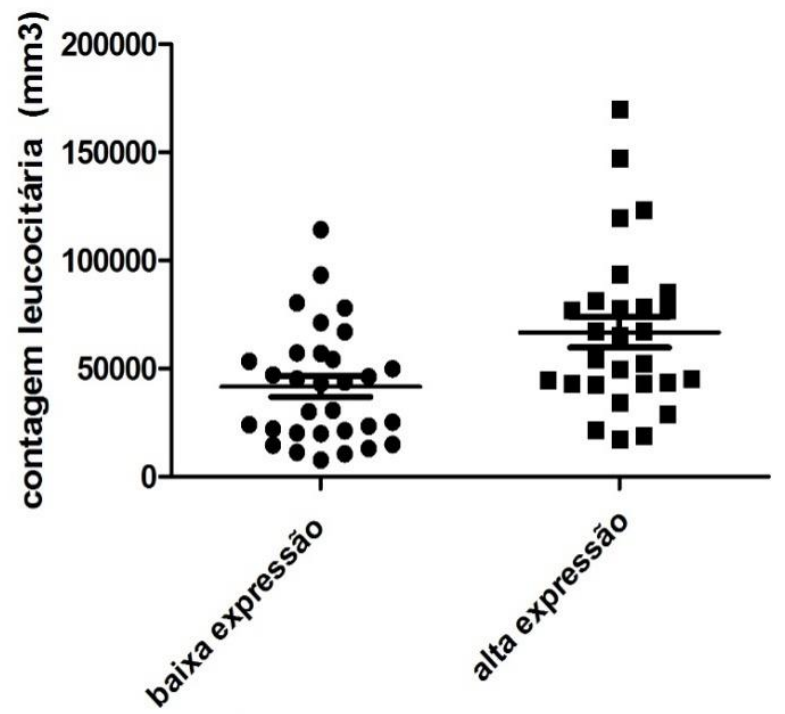

Figura 24. Expressão do gene SETD2 e contagem leucocitária, sendo $p=0,0042$ (Teste Mann Whitney com $p<0,05)$. 


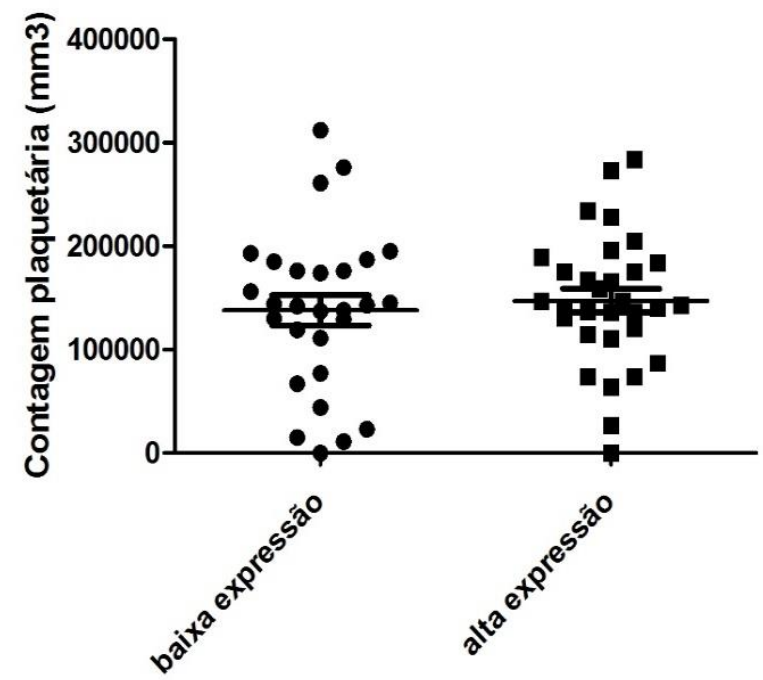

Figura 25. Padrão de expressão do gene SETD2 e contagem plaquetária, com $p=0,3410$ (Teste de Mann Whitney sendo $p=0,05$ ).

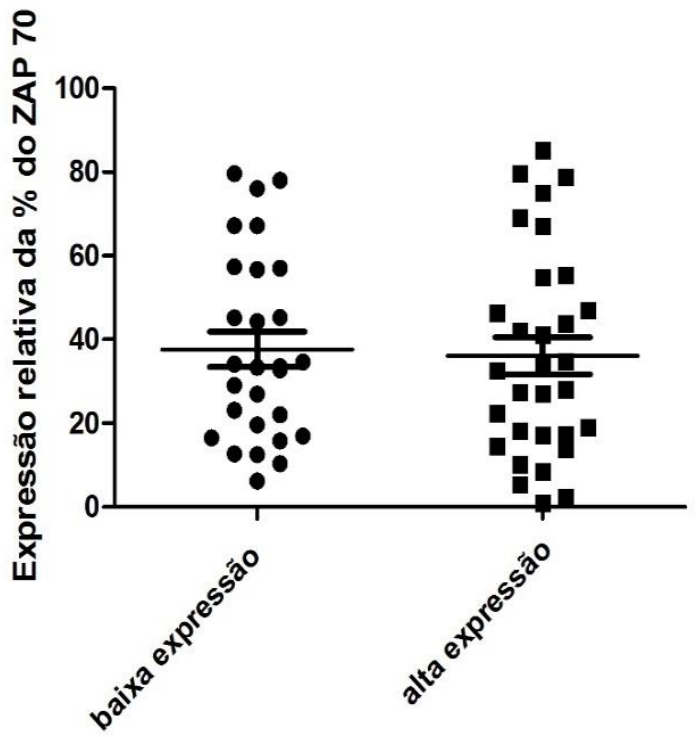

Figura 26. Padrão de expressão do ZAP-70 e expressão do gene SETD2 com $p=0,3664$ (Teste de Mann Whitney sendo $p=0,05$ ). 


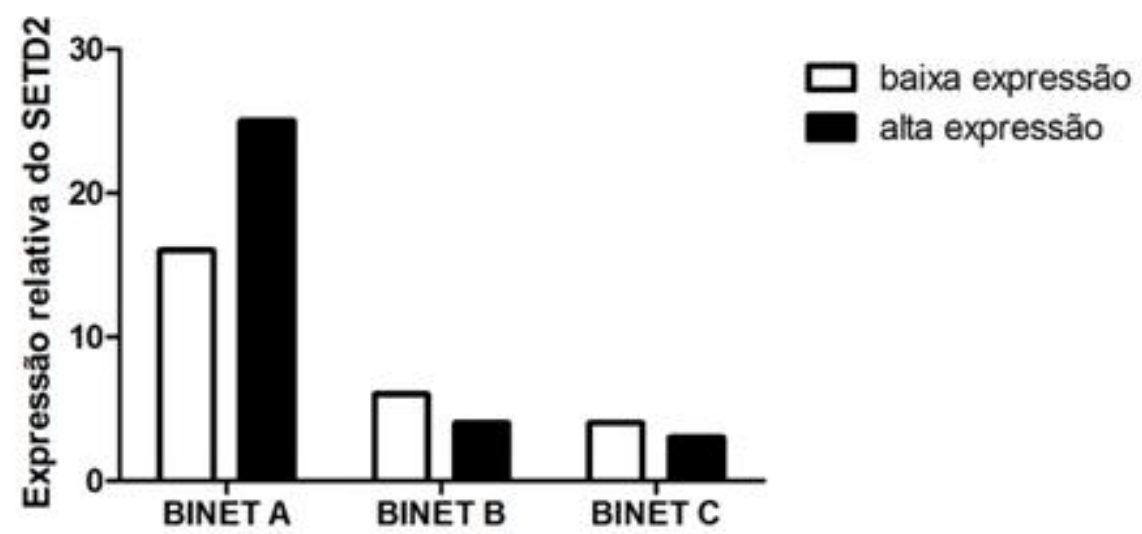

Figura 27. Expressão relativa do gene SETD2 e estadiamento clínico de BINET com $p=0,38$ (Teste de Mann Whitney sendo $p=0,05$ ).

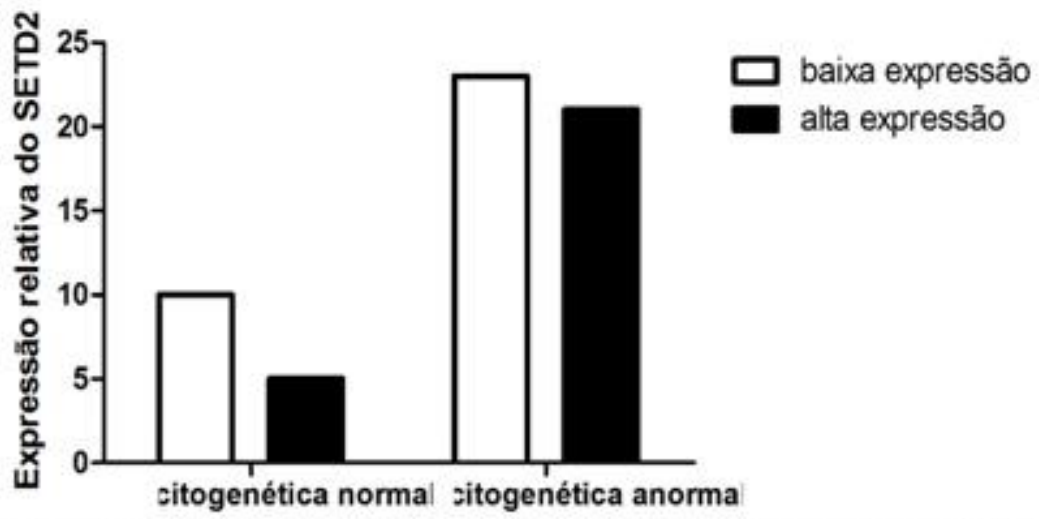

Figura 28. Expressão do gene SETD2 e anormalidades citogenéticas com $\mathrm{p}=\mathbf{0 , 2 5 3 5}$ (Teste de Fisher, risco relativo=1.25, IC95\%: 0.8084 a 2.012 , sendo $p<0.05$ ).

O gene SETD2 codifica uma proteína metiltransferase de histona especifica para lisina de posição 36histona H3(H3K36), sendo associcado com a hiperfosforilação do RNA polimerase II (130). A perda da expressão desse gene foi apontada como um passo importante na progressão de tumores sólidos (131). Este gene já foi relacionado à carcinogênese de mama e renal, onde em amostras os cânceres apresenta-se hipoexpresso em estadios mais avançados (132). 


\subsection{PERFIL DE EXPRESSÃO GÊNICA DE SETD3 NAS AMOSTRAS DE LLC}

O padrão de expressão relativa do gene SETD3 entre as amostras dos pacientes portadores de LLC quando comparada aos controles não apresentou diferença estatística (Figura 29).

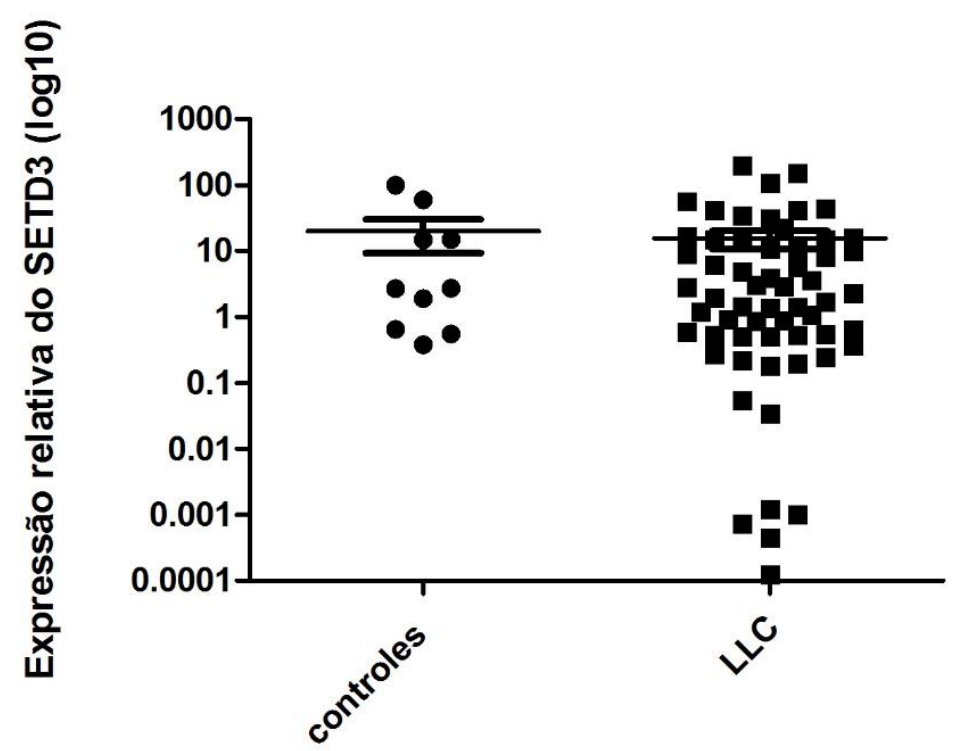

Figura 29. Padrão de expressão relativa do gene SETD3 entre amostras controles e pacientes com LLC sendo $\mathbf{p}=\mathbf{0 , 1 9 0 0}$ (Teste Mann Whitney com $p<0,05$ ).

Os pacientes foram divididos em dois grupos: baixa e alta expressão, de acordo com o cálculo do cutt off =1,9 (Figura 10). Os pacientes portadores de LLC que pertencem ao grupo com baixa expressão do gene SETD3 apresentam uma maior contagem leucocitária ( $p=0,0048)$ com significância estatística sendo (Teste de Mann Whitney $\mathrm{p}<0,05$ ) (Figura 30). Assim, a baixa expressão relativa do gene SETD3 pode estar correlacionado com duplicação leucocitária e aumento da massa tumoral. As demais características clínicas e prognósticas não apresentaram significado estatístico: contagem plaquetária (Figura 31), expressão do ZAP-70 (Figura 32), estadiamento de Binet (Figura 33) e anormalidades citogenéticas (Figura 34). 


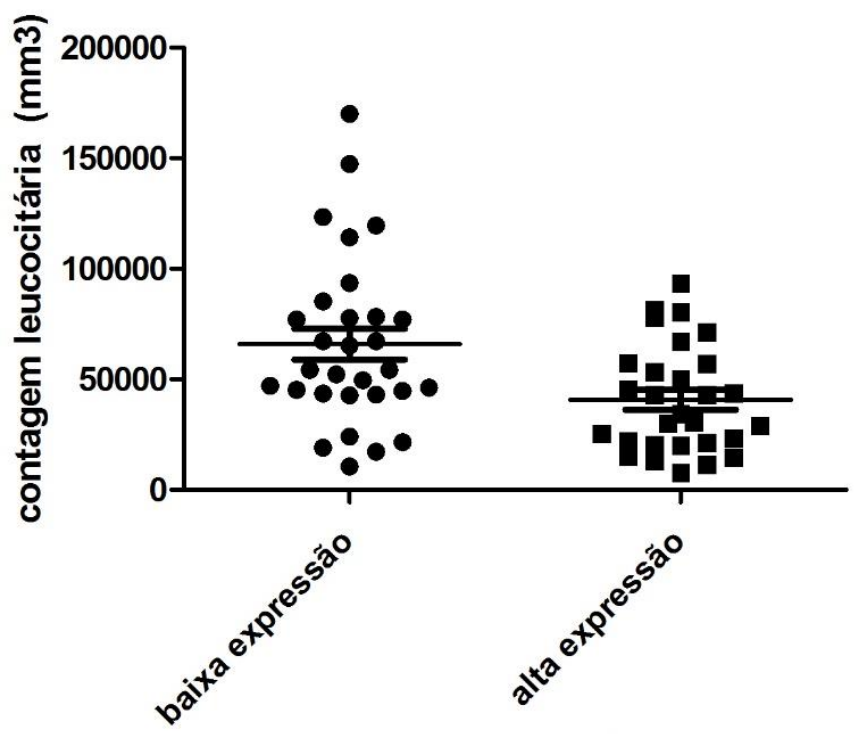

Figura 30. Padrão de expressão relativa do gene SETD3 e contagem leucocitária, sendo $\mathrm{p}=\mathbf{0 , 0 0 4 8}$ (Teste Mann Whitney com $\mathrm{p}<0,05)$.

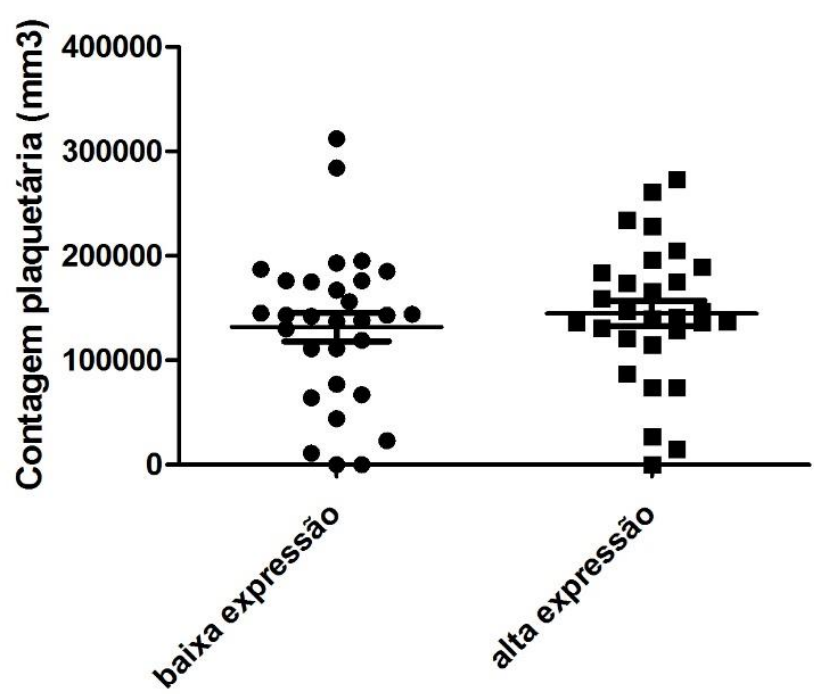

Figura 31. Padrão de expressão relativa do gene SETD3 e a contagem plaquetária, sendo $p=$ $\mathbf{0 , 2 6 4 6}$ (Teste Mann Whitney com $\mathrm{p}<0,05$ ). 


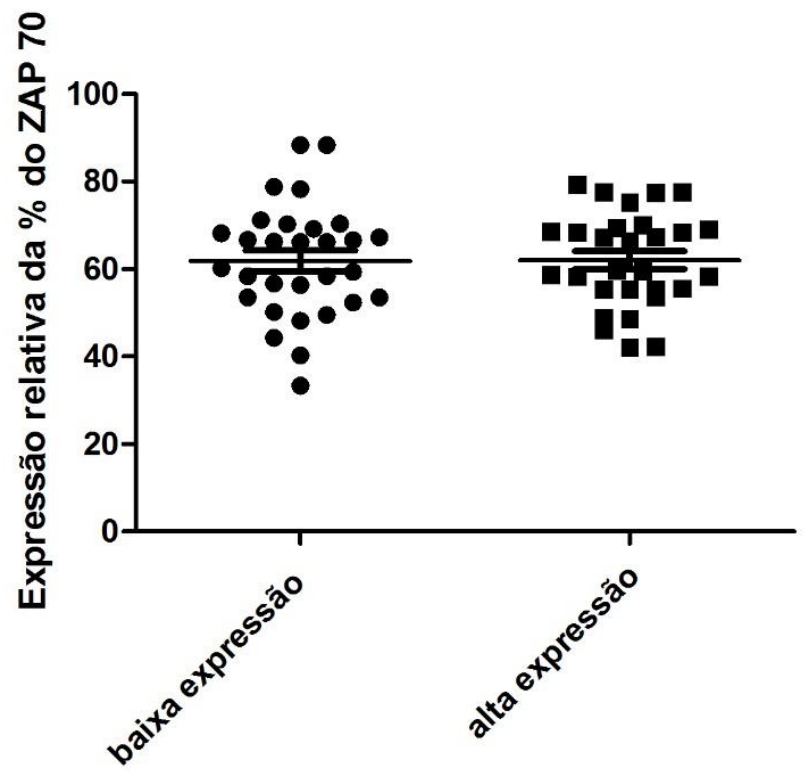

Figura 32. Padrão de expressão do ZAP-70 e gene SETD3 sendo $p=0,4159$ (teste de Mann Whitney sendo $p<0,05$ ).

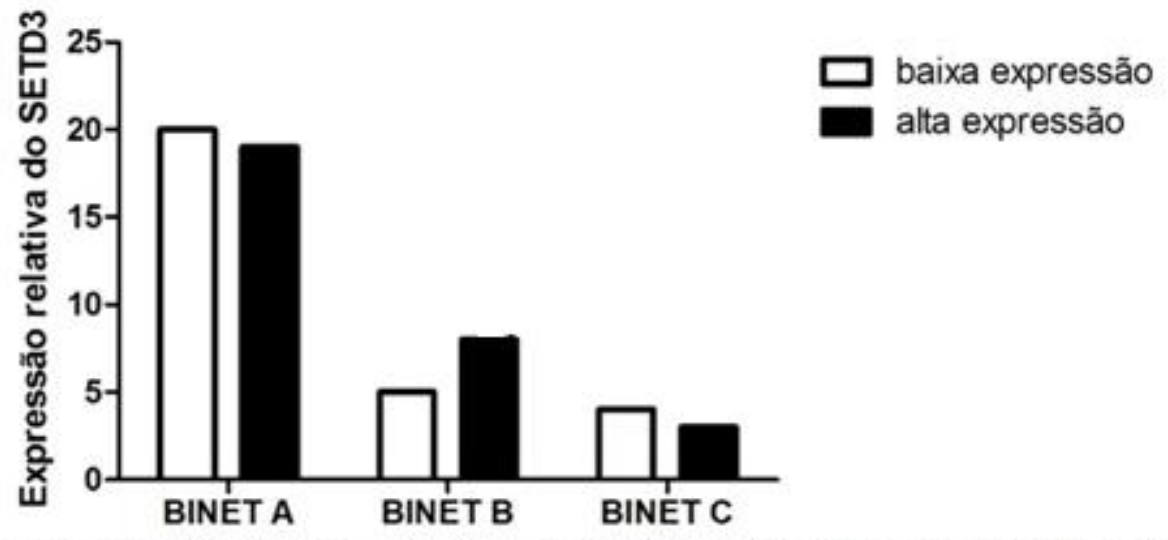

Figura 33. Padrão de expressão do gene SETD3 e estadiamento clínico de BINET, sendo $\mathrm{p}=\mathbf{0 , 6 5 5 7}$ (Teste de Qui-Quadrado sendo $\mathrm{p}<0,05$ ). 


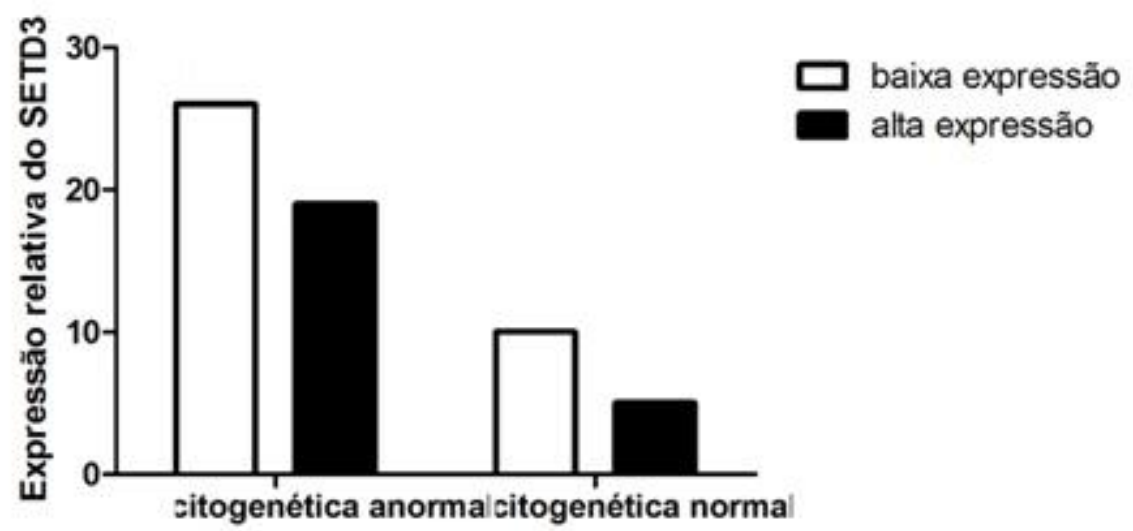

Figura 34. Expressão relativa do SETD3 e presença de anormalidades citogenéticas, sendo $p=0,38$ (Teste de Mann Whitney com $p<0,05$ ).

A correlação quanto ao padrão de expressão relativa entre os genes SETD2 e SETD3 não demostrou com relevância significativa, sendo $r=0,18$ (Correlação de Spearmann com $p<0,0001)$.

Foi identificado uma relação entre a metilação do gene SETD3 e morte celular por apoptose interagindo na regulação no ciclo celular, já que a hiperexpressão do gene SETD3 poderia diminuir a viabilidade celular e ativar a caspase 3. A supressão (silenciamento) pelo gene SETD3 foi relacionada com a biologia tumoral dos linfomas de células B (105). Assim, nossos dados inferem que baixa expressão do SETD3 pode estar associada a replicação dos linfócitos $B$, semelhante aos achados em linfomas de células $B$.

\subsection{PERFIL DE EXPRESSÃO GÊNICA DE SETD4 NAS AMOSTRAS DE LLC.}

A expressão relativa do gene SETD4 nas amostras de LLC quando comparado aos controles pode ser visualida abaixo (Figura 35). Os achados entre o padrão de expressão do gene SETD4 nas amostras controles quando comparadas as amostras de LLC não apresentaram significância estatística. 


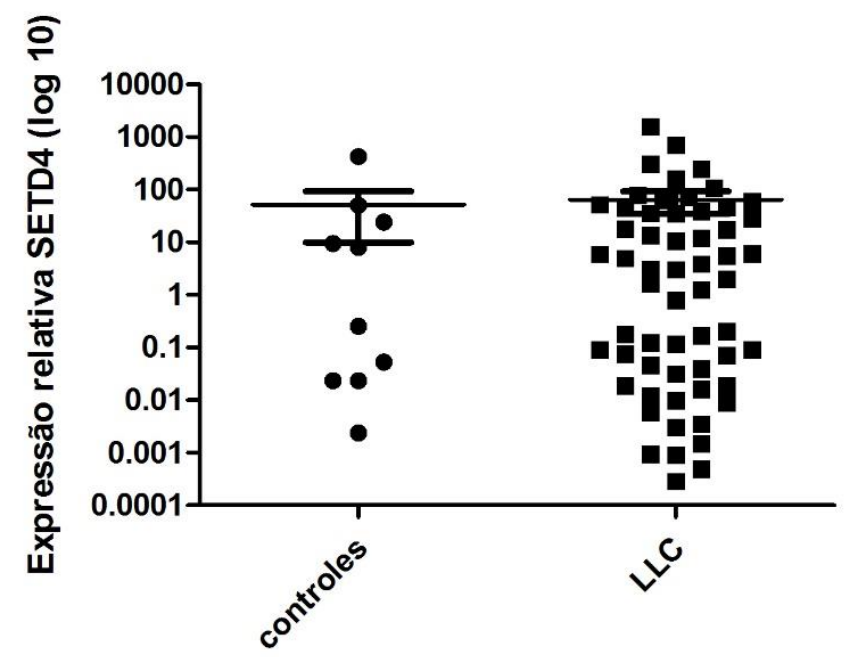

Figura 35. Expressão relativa do gene SETD4 nas amostras de LLC versus controles, sendo $p=0,4898$ (Teste de Mann Whitney com $p<0,05$ ).

Os pacientes foram subdivididos em dois grupos, como citado anteriormente, sendo o cálculo do cutt off=2,96 para o gene SETD4. A contagem leucocitária entre os grupos de baixa e alta epxressão não demosntrou relevância estatística (Figura $36)$.

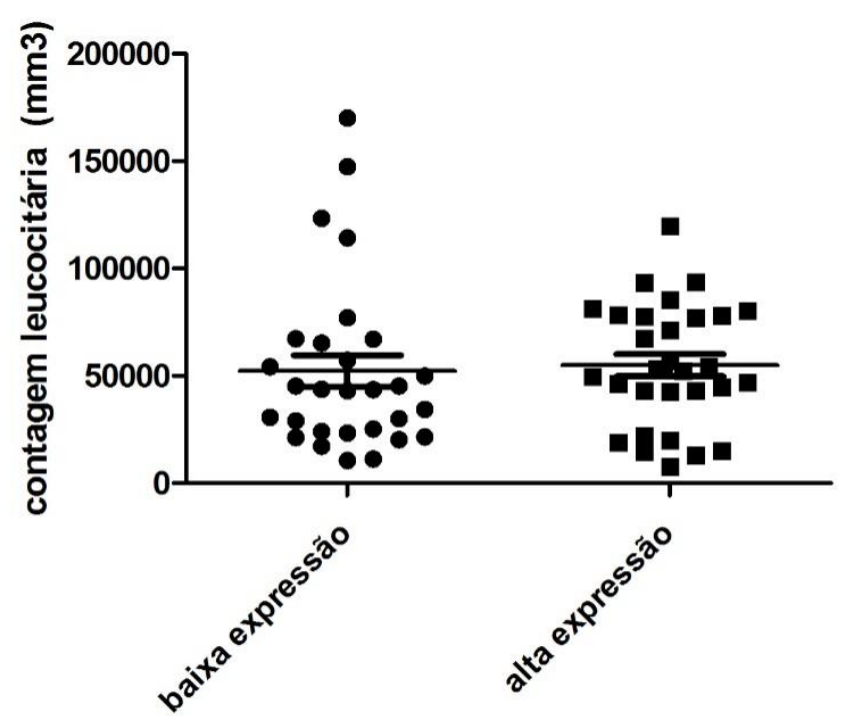

Figura 36. Padrão de expressão entre gene SETD4 e contagem leucocitária, com p=0,1530 (Teste de Mann Whitney com $\mathrm{p}<0,05$ ).

A contagem plaquetária (Figura 37), padrão de expressão do ZAP-70 (Figura 38), estadiamento clínico de BINET (Figura 40) não apresentaram significância estatística entre os pacientes com baixa e alta expressão relativa do gene SETD4. A 
análise citogenética (Figura 40) infere que os pacientes com alta expressão do gene SETD4 apresentam um percentual elevado de anormalidades citogenéticas, porém sem significância estatística, $p<0,05$.

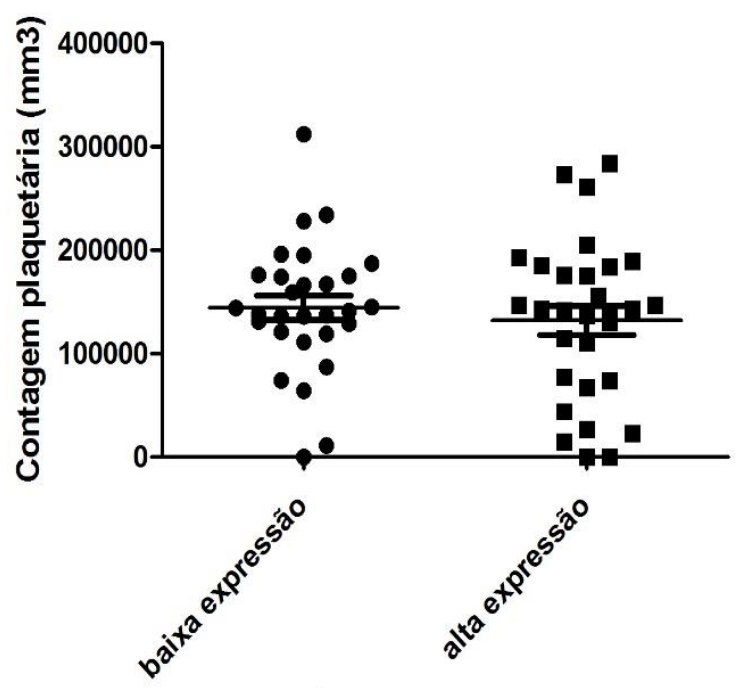

Figura 37. Expressão relativa do gene SETD4 e contagem plaquetária com $p=0,3523$ (Teste de Mann Whitney com $p=0,05)$.

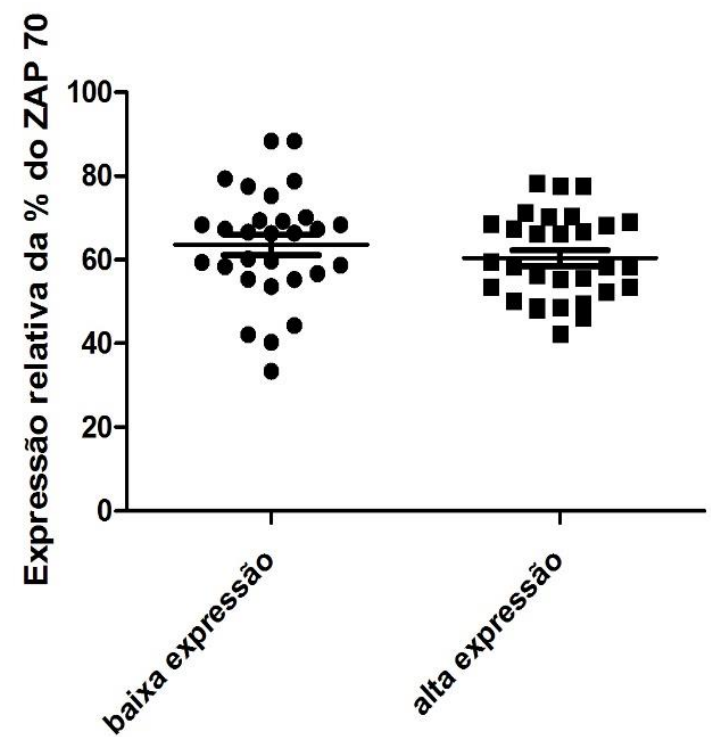

Figura 38. Expressão relativa de SETD4 em relação do ZAP-70 com p= 0,1185 (Teste de Mann Whitney sendo $p=0,05)$. 


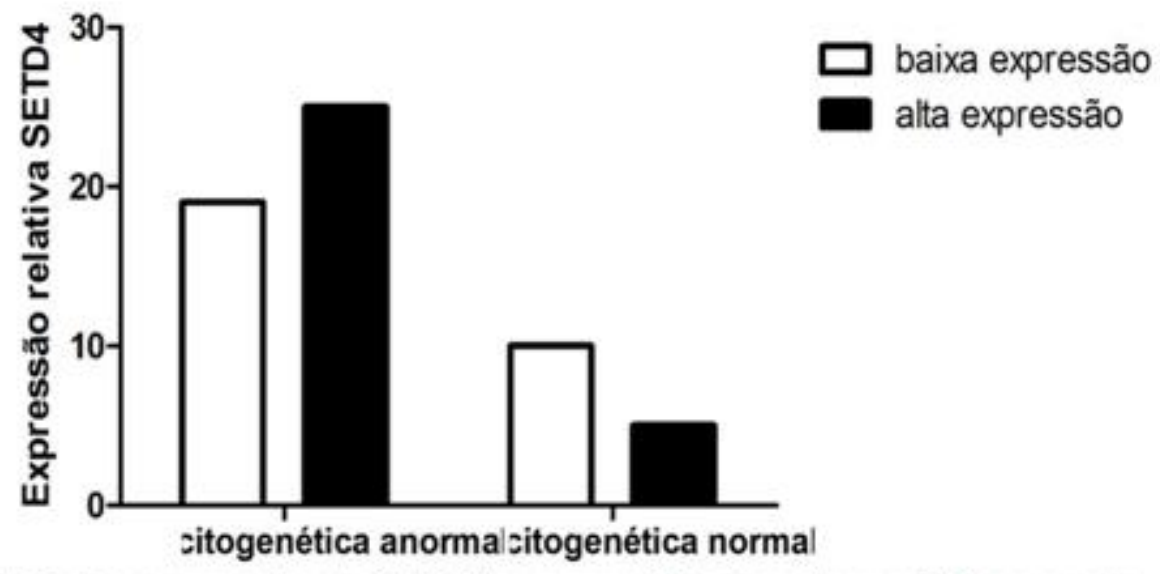

Figura 39. Padrão de expressão de SETD4 e anormalidades citogenéticas sendo $\mathrm{p}=\mathbf{0 , 1 0 1 4}$ (Teste Fisher com $\mathrm{p}<0,05$ ).

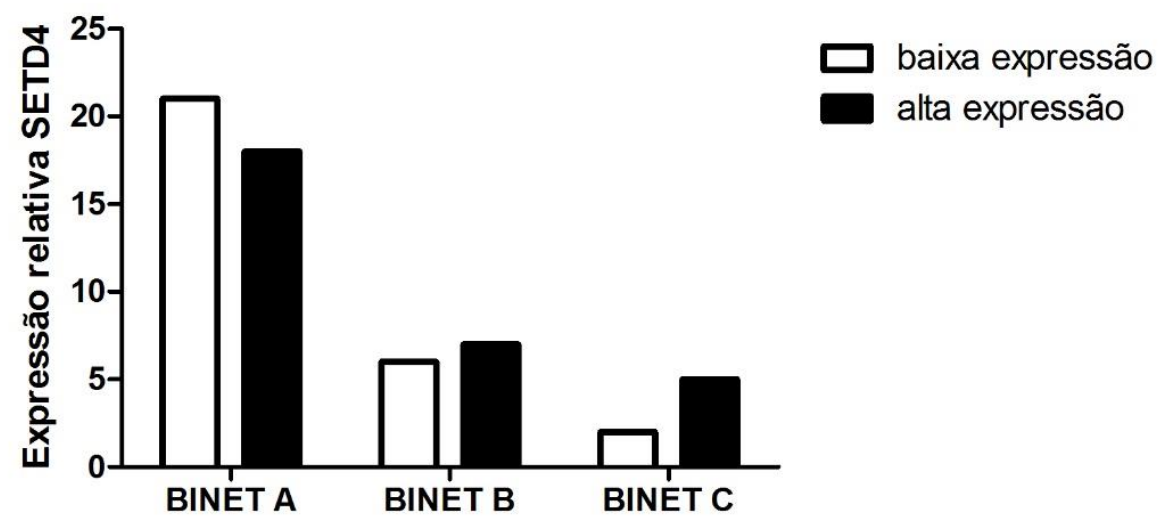

Figura 40. Padrão de expressão relativa do gene SETD4 e estadiamento de BINET sendo $\mathrm{p}=\mathbf{0 , 4 5 4 5}$ (Teste de Qui-quadrado com $\mathrm{p}<0.05$ )

A atividade enzimática da proteína SETD4 ainda não está bem estabelecida, porém dados recentes apotam que a mesma esteja presente no citosol e núcleos das células cancerígenas e atuando na ciclina D1, com efeito no ciclo celular. Os dados recentes demonstram estar superexpresso nos cânceres de mama triplo negativo. Podemos sugerir que o SETD4 não tenha ação na leucemogênese da LLC. 


\subsection{PERFIL DE EXPRESSÃO GENICA DO SETD5 EM AMOSTRAS DE LLC.}

O padrão de expressão relativa do gene SETD5 é demonstrado abaixo (Figura 41), onde os pacientes portadores de LLC não demonstraram significância estatística quanto ao padrão de expressão do gene citado. O papel do SETD5 na tumorogênese e leucemogênese ainda não está bem definido.

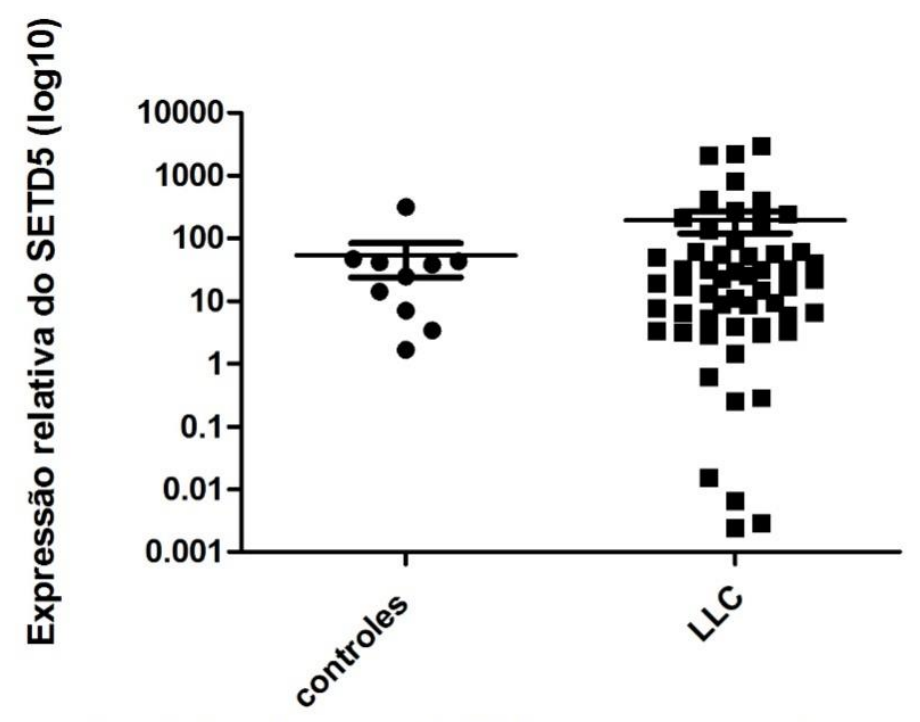

Figura 41. Expressão relativa do gene SETD5 entre os controles e amostras LLC, sendo $\mathbf{p}=\mathbf{0 , 3 8 4 0}$ (Teste de Mann Whitney com $\mathrm{p}<0,05$ ).

Posteriormente, dividimos as amostras de LLC em dois grupos (alta e baixa expressão) de acordo com a expressão relativa do gene SETD5 e utilizando o cutt off $=0,59$. A contagem leucocitária nos pacientes portadores de LLC apresentou significância estatísticacom $p=0,0013(p<0,05)$ em comparação aos controles, sendo os portadores de LLC com baixa expressão relativa do geneSETD5 com maior contagem leucocitária (Figura 42). Assim, sugerimos que a supressão da expressão do gene SETD5 pode aumentar a proliferação de células $B$ e consequentemente progressão da doença. 


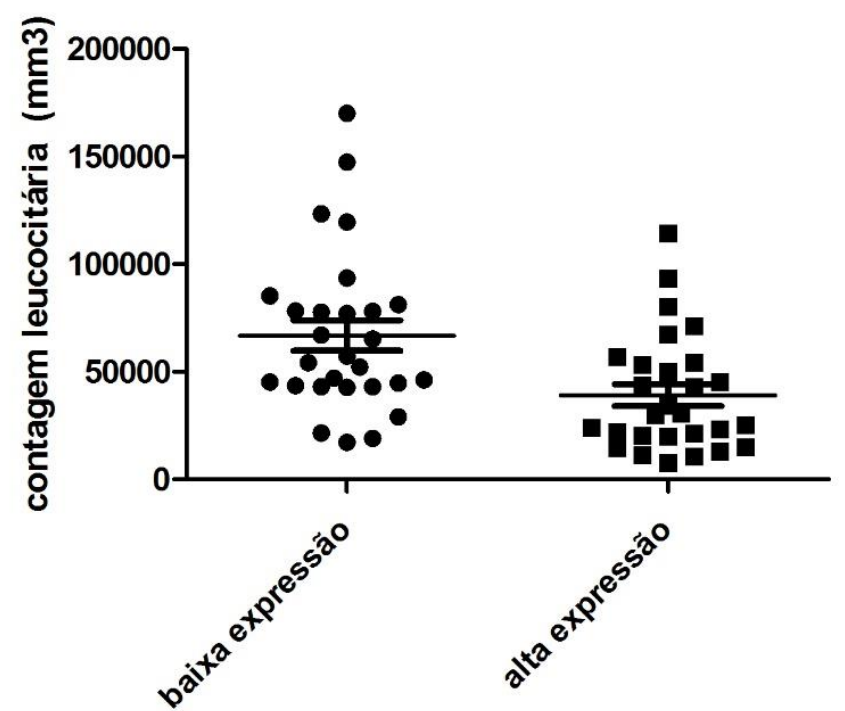

Figura 42. Padrão de expressão relativa do gene SETD5 e contagem leucocitária, $p=0,0013$ (Teste Mann Whitney com $\mathrm{p}<0,05$ ).

A contagem plaquetária (Figura 43) e a expressão de ZAP-70 (Figura 44) não apresentaram relevância estatística entre os grupos de baixa e alta expressão.

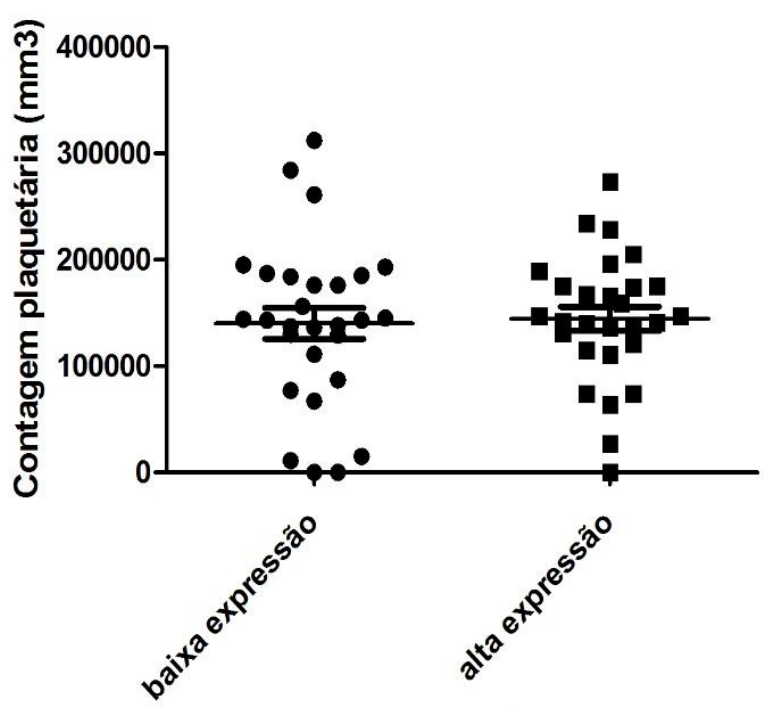

Figura 43. Padrão de expressão relativa do gene SETD5 e contagem plaquetária, $p=0,4220$ (teste Mann Whitney com $\mathrm{p}<0,05$ ). 


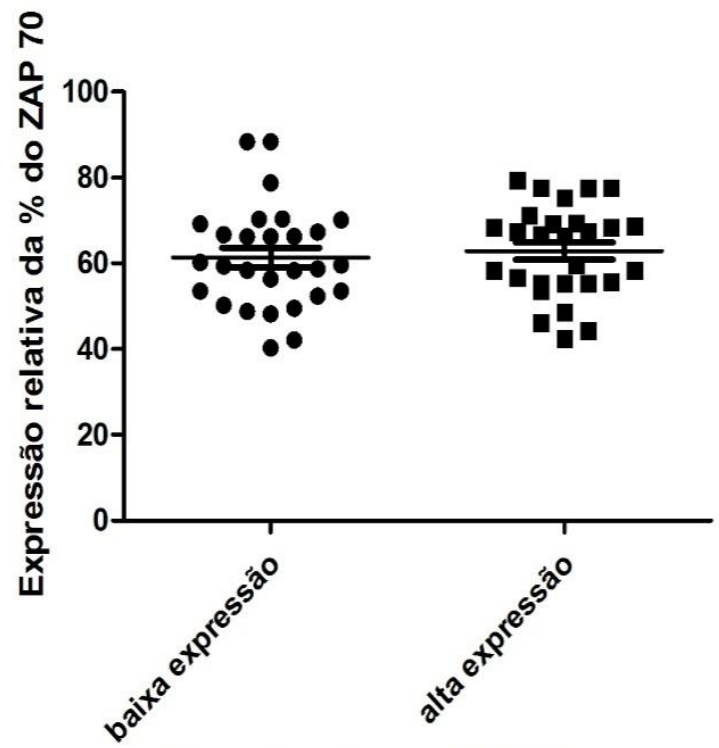

Figura 44. Padrão de expressão relativa do gene SETD5 e expressão do ZAP-70, $p=0,2255$ (Teste Mann Whitney com $\mathrm{p}=0,05$ ).

Quanto as anormalidades citogenéticas, o grupo de baixa expressão apresentou significância estatística, com um maior número de casos de citogenéticas anormais quando comparado ao grupo de alta expressão, $p=0,036$, com risco relativo de 1.97, IC95\%:0,93 a 4,17 sendo $\mathrm{p}<0,05)$. A anormalidade citogenética mais frequentes foi novamente hiperploidia $(n=20)$.

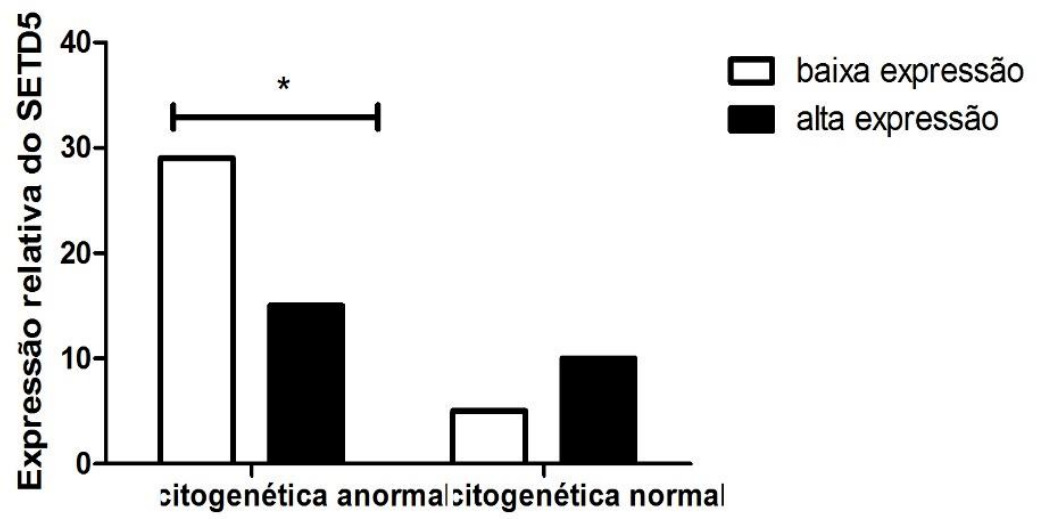

Figura 45. Padrão de expressão relativa do gene SETD5 e anormalidades citogenéticas com p= 0,036 (Teste Mann Whitney com p<0,05).

O estadiamento clínico de Binet não evidenciou significância estatística entre quanto ao padrão de expressão relativa do gene SETD5 (Figura 46). 


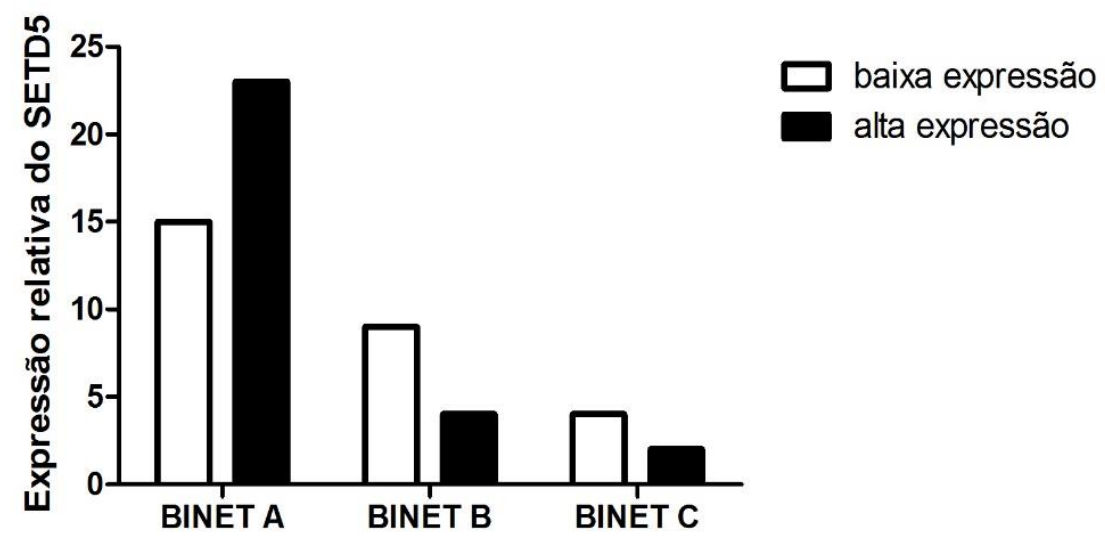

Figura 46. Padrão de expressão relativa do gene SETD5 e estadiamento de BINET sendo $\mathbf{p}=\mathbf{0 , 1 9}$ (Teste de Qui-Quadrado com $p<0,05$ ).

Realizamos a correlação de expressão entre os genes SETD5 e SETD4 pelo teste de Spearmann, não evidenciando associação na regulação de suas expressões (sendo $r=0,02$ ). Diante das semelhanças entre o padrão de expressão relativa dos genes SETD5 e SETD3 entre suas amostras dos controles e tumorais, realizamos o estudo de correlação pelo Teste de Spearmann (Figura 48), onde verificamos um padrão de correlação de expressão dos referidos genes com significância estatística, $r=0,6(p<0,0001)$. Assim, podemos sugerir que a associação da baixa expressão dos genes SETD3 e SETD5 pode contribuir para proliferação celular da LLC.

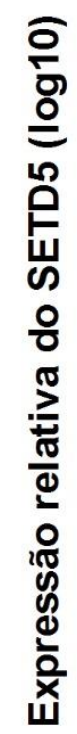

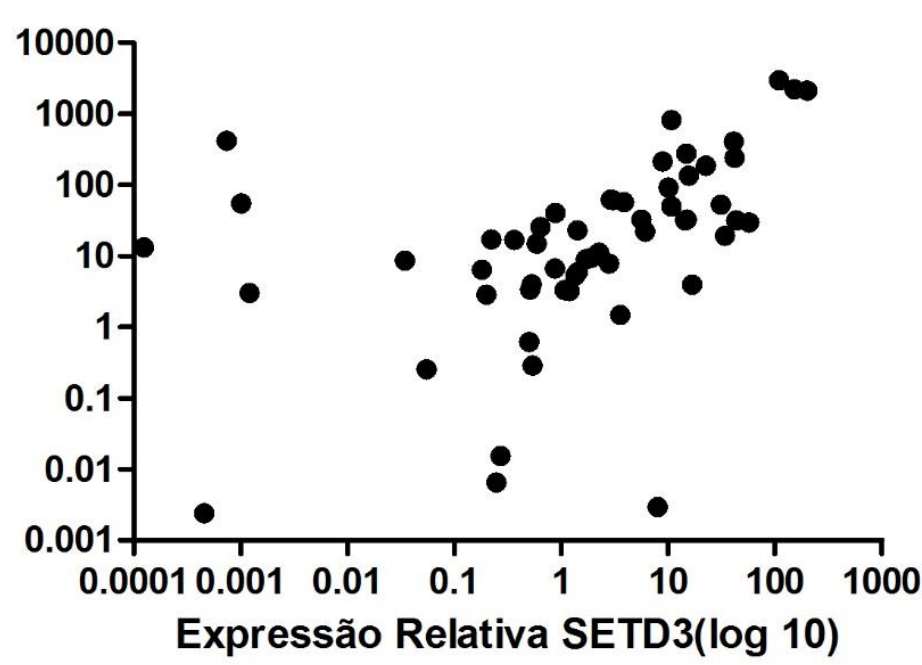

Figura 47. Correlação entre a expressão relativa dos genes SETD5 e SETD3, sendo $r=0,6062$ (Correlação de Spearmann, com $p<0,0001$ ). 


\subsection{PADRÃO DE EXPRESSÃO GÊNICA DOSETD6 EM AMOSTRAS DE LLC.}

O padrão de expressão do SETD6 demostrou uma baixa expressão nos portadores de LLC quando comparados aos controles (Figura 48), com significância estatística sendo $p=0,0244(p<0.05)$.

Como citado anteriormente, especula-se que este gene esteja envolvido com a diferenciação celular, pois foi demonstrado que a depleção do mesmo gene levou a diferenciação das células tronco embrionárias de camundongos (109).

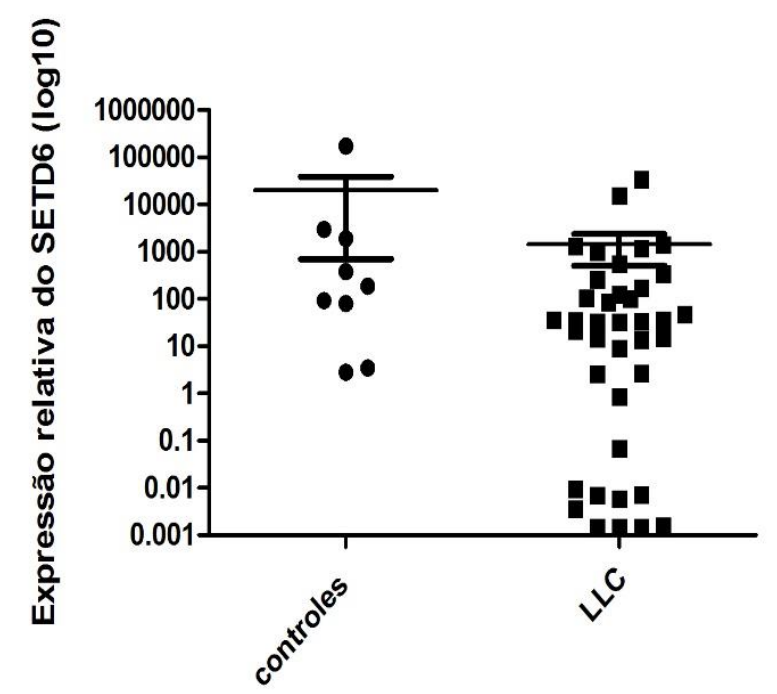

Figura 48. Padrão de expressão relativa do gene SETD6 entre os controles e os portadores de LLC com $\mathrm{p}=\mathbf{0 , 0 2 4 4}$ (Teste Mann Whitney com $\mathrm{p}<0,05$ ).

As demais características clínicas e prognósticas da LLC foram avaliadas de acordo com padrão de expressão relativa do gene SETD6, dividimos em dois grupos de acordo com o cutt off $=32,59$. A contagem leucocitária (Figura 49), contagem plaquetária (Figura 50), expressão do ZAP-70 (Figura 51), presença das anormalidades citogenéticas (Figura 52) e estadiamento de BINET (Figura 53) não foram estatisticamente significantes $(p<0,05)$. Realizou-se a correlação de Spearmann entre o gene SETD4 e SETD6 não verificando significância estatística $(r=0,14)$. 


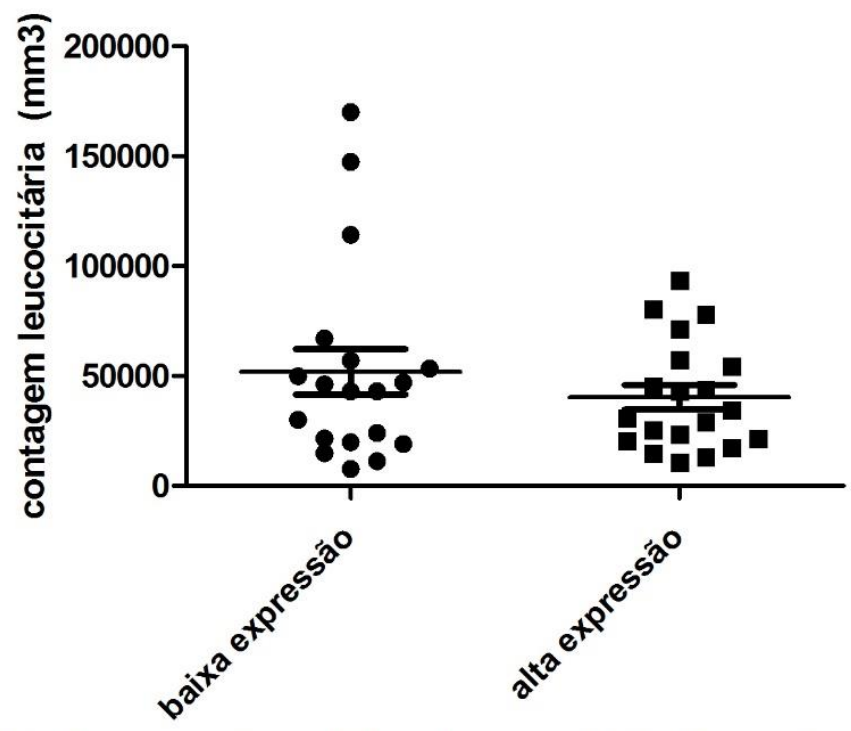

Figura 49. Padrão de expressão relativa do gene SETD6 e contagem leucocitária com $p=$ $\mathbf{0 , 3 4 7 0}$ (teste Mann Whitney com $p<0,05$ ).

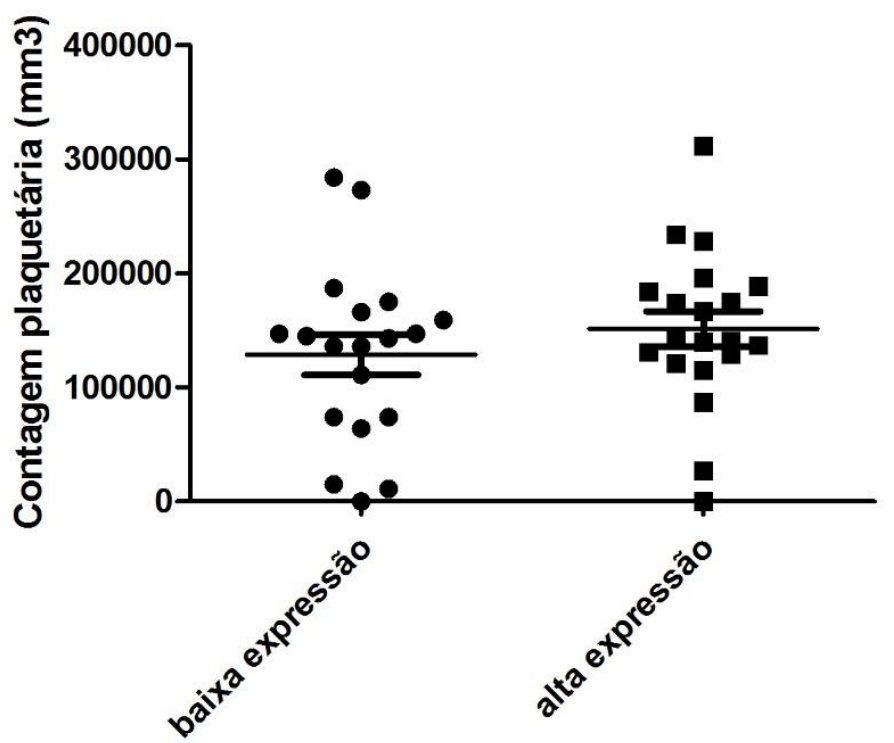

Figura 50. Padrão de expressão relativa do gene SETD6 e contagem plaquetária com $\mathrm{p}=0,1805$ (Teste Mann Whitney com $\mathrm{p}<0,05$ ). 


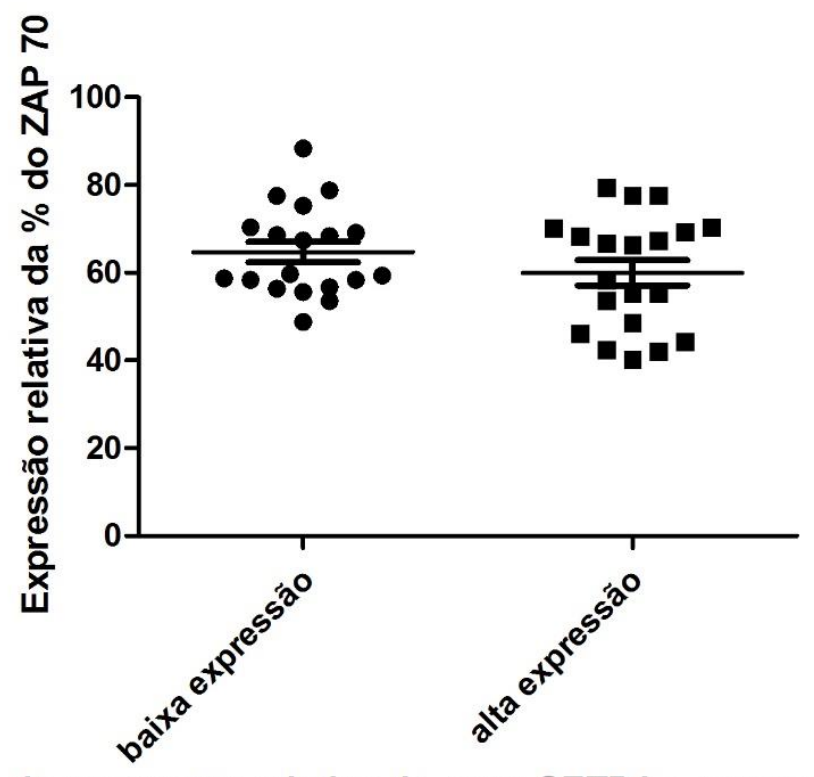

Figura 51. Padrão de expressão relativa do gene SETD6 e expressão do ZAP-70, com $p=$ $\mathbf{0 , 1 1 3 5}$ (Teste Mann Whitney com $p<0,05$ ).

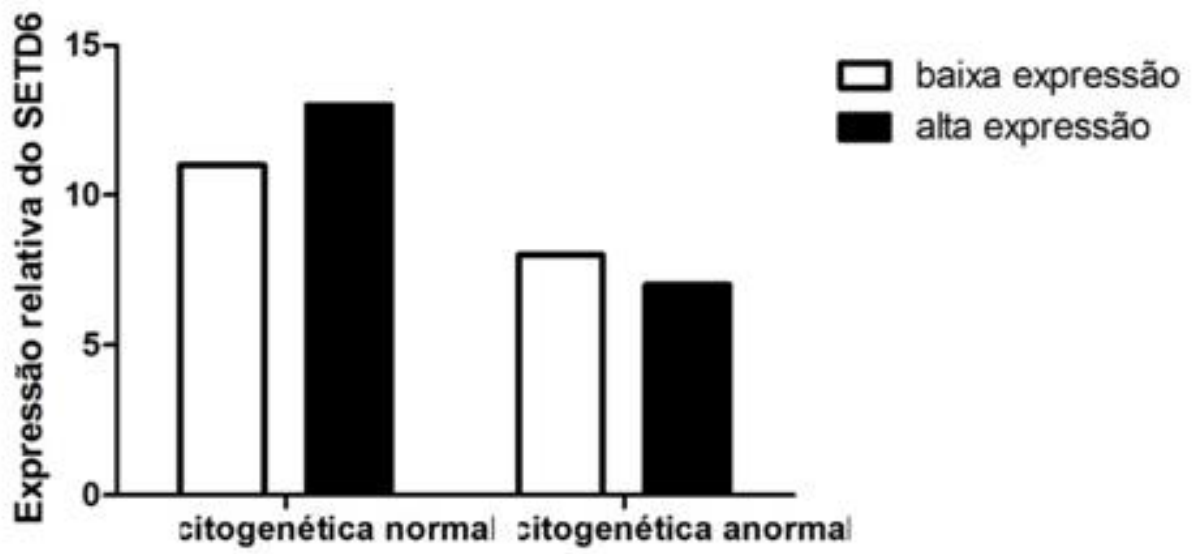

Figura 52. Padrão de expressão relativa do gene SETD6 e presença de anormalidades citogenéticas, com $\mathbf{p}=\mathbf{0 , 4 4 9 5}$ (Teste de Fischer com $\mathrm{p}<0,05$ ). 


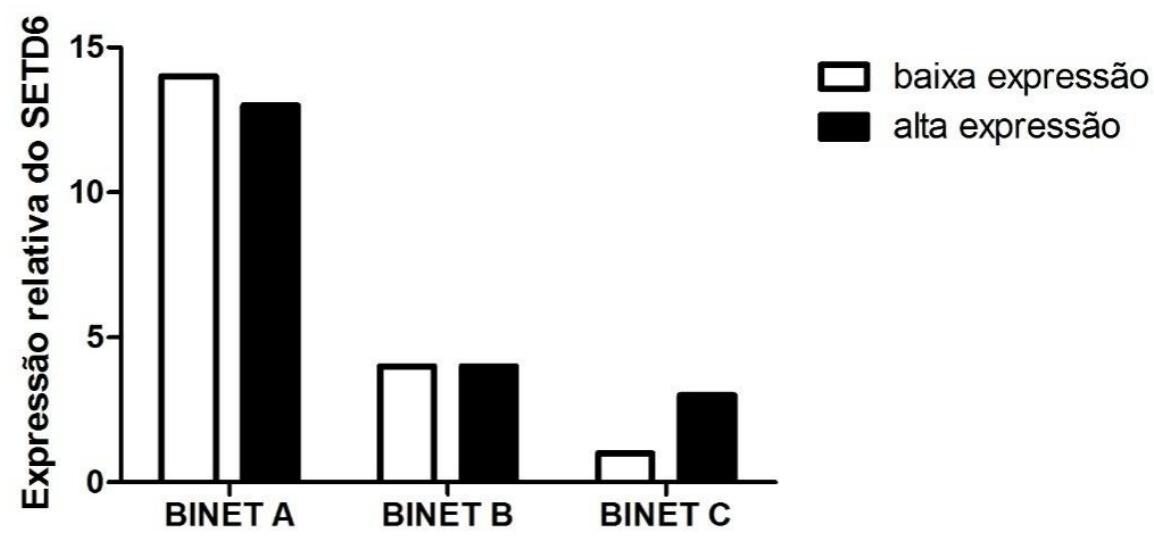

Figura 53. Padrão de expressão relativa do gene SETD6 e estadiamento clínico de BINET com $\mathbf{p}=\mathbf{0 , 6 0}$ (Teste de Qui-Quadrado com $\mathrm{p}<0,05$ ).

Sabe-se, que o SETD6está envolvido na indução das células tronco embrionária de camundongos a se diferenciarem (132). O SETD6 monometila a proteína Re1A nuclear na lisina 310 e atenua a sinalização de NF-kappa $\beta$ por encaixe de GLP (uma outra metiltransferase) em genes alvo para gerar um estado de cromatina silenciosa, efetivamente tornando a ligação entre $\operatorname{Re} 1 \mathrm{~A}$ e a cromatina inerte. A não regulação de NF-Kappa $\beta$ está ligado a processos inflamatórios patológicos e câncer (133).

O gene SETD6 inibe a sinalização NF-kappa $\beta$ em diversos tipos de células, incluindo células embrionárias humanas. A associação da via NF-Kappa $\beta$ nas neoplasias linfóides é muito estudada e com promissoras molécula agindo em sítios celulares exclusivos para atuação como terapias alvo. Foi identificado a ação do SETD6 como um um co-ativador de vários genes que respondem ao estrogénio, tais como PGR e TFF1. Assim, o silenciamento de SETD6 em várias linhagens de células de carcinoma da mama induziu defeitos de proliferação celular, acompanhados pelo aumento da expressão do inibidor CDKN1A e indução de apoptose ciclo celular (133). Podemos sugerir que o silenciamento do SETD6 nas células de LLC (quando comparado o seu nível de expressão aos controles), pode atuar na via $N F-k \beta$, sendo esta de suma importância para manutenção e desenvolvimento da leucemogênese nas LLC. 


\subsection{PADRÃO DE EXPRESSÃO GÊNICA DO SETD7 EM AMOSTRAS DE LLC.}

O gene SETD7 já possui várias citações bibliográficas da sua relação com alterações do $P 53$ e na tumorogênese. O padrão de expressão relativa do gene SETD7 entre as amostras controles e portadores de LLC pode ser avaliado abaixo (Figura 54). Evidenciamos que o padrão de expressão relativa do gene SETD7 nas amostras de LLC estão com padrão de expressão superior ao nível dos controles, porém não foi significativo estatisticamente $(p=0,4279)$.

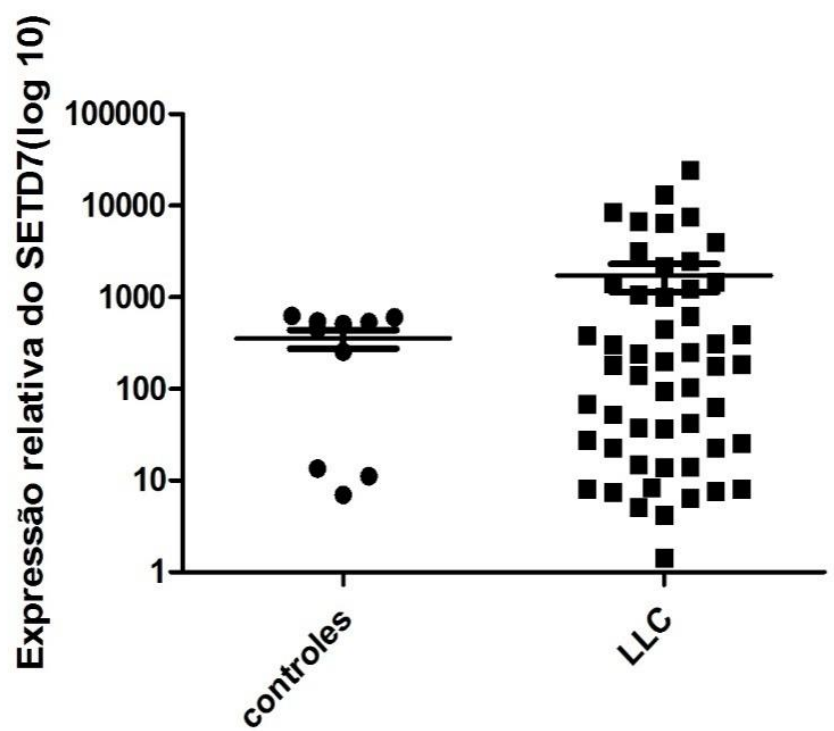

Figura 54 . Padrão de expressão relativa do gene SETD7 entre amostras controles e pacientes com LLC, sendo $\mathbf{p}=\mathbf{0 , 4 2 7 9}$ (Teste Mann Whitney com $p<0,05$ ).

Realizamos a divisão em dois grupos seguindo o cutt off =161,3 (Figura 10) do padrão de expressão relativa do gene SETD7: grupo de baixa expressão e grupo de alta expressão. A expressão relativa do gene SETD7 dos dois grupos de expressão foi analisada com as características clínicas e prognósticas definidas previamente: contagem leucocitária (Figura 56), contagem plaquetária (Figura 57), expressão do ZAP-70 (Figura 58), estadiamento clínico de BINET (Figura 59) e presença das anormalidades citogenéticas (Figura 60). Nenhuma das características citadas houve significância estatística quanto ao padrão de expressão do SETD7,sendo $p<0,05$. 


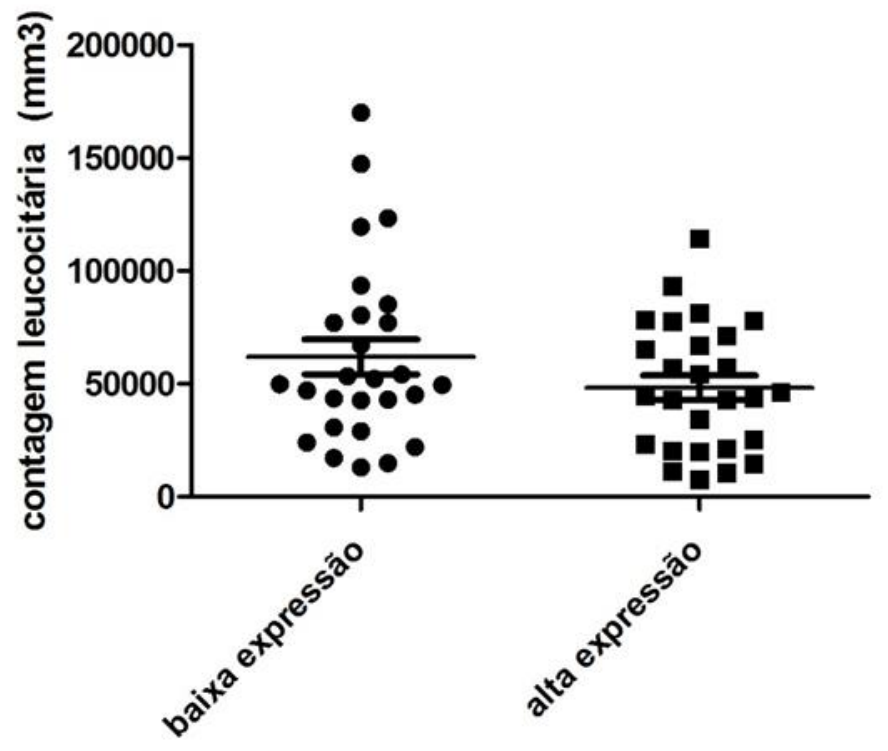

Figura 55 . Padrão de expressão relativa do gene SETD7 e contagem leucocitária com $\mathrm{p}=\mathbf{0 , 1 3 9 8}$ (Teste Mann Whitney com $\mathrm{p}<0,05$ ).

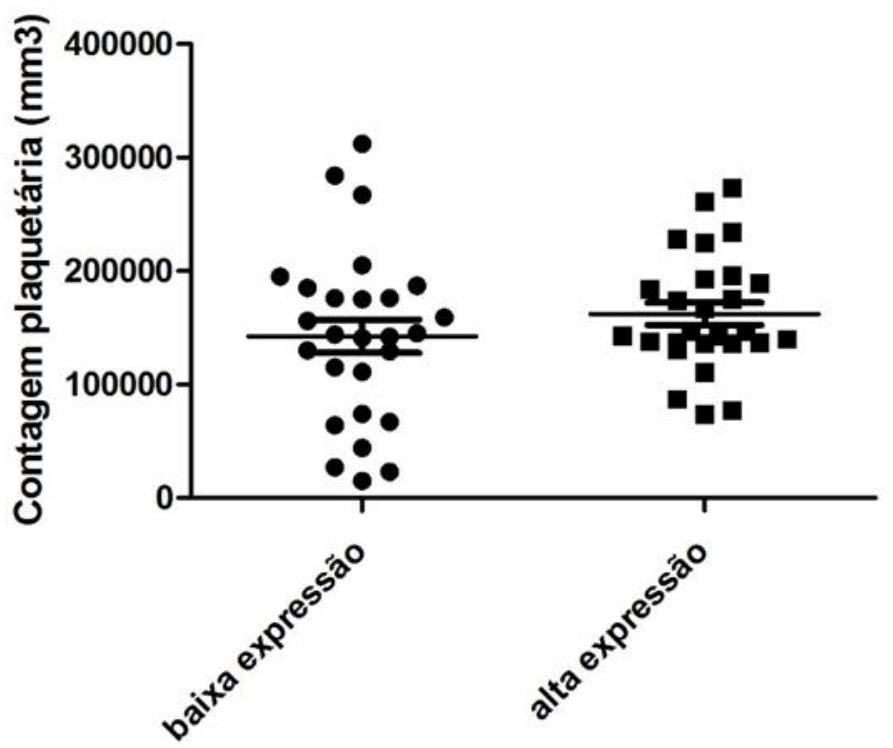

Figura 56. Padrão de expressão relativa do gene SETD7 e contagem plaquetária com $\mathrm{p}=\mathbf{0 , 1 6 8 5}$ (Teste Mann Whitney com $\mathrm{p}<0,05)$. 


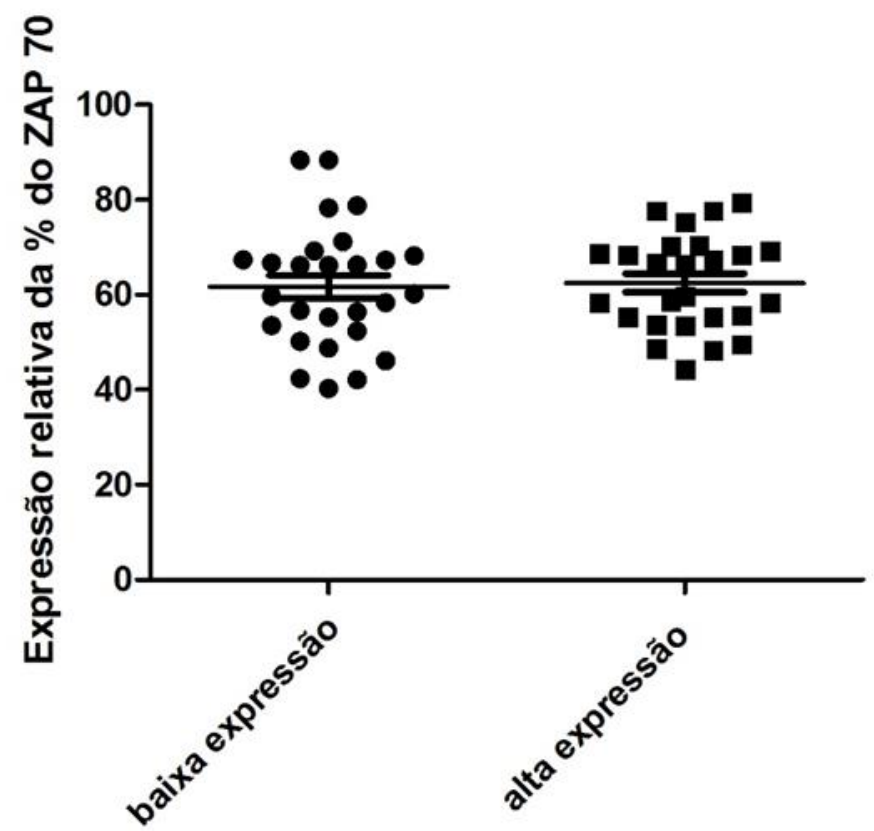

Figura 57. Padrão de expressão relativa do gene SETD7 e expressão do ZAP com $p=0,3991$ (teste Mann Whitney com $p<0,05$ ).

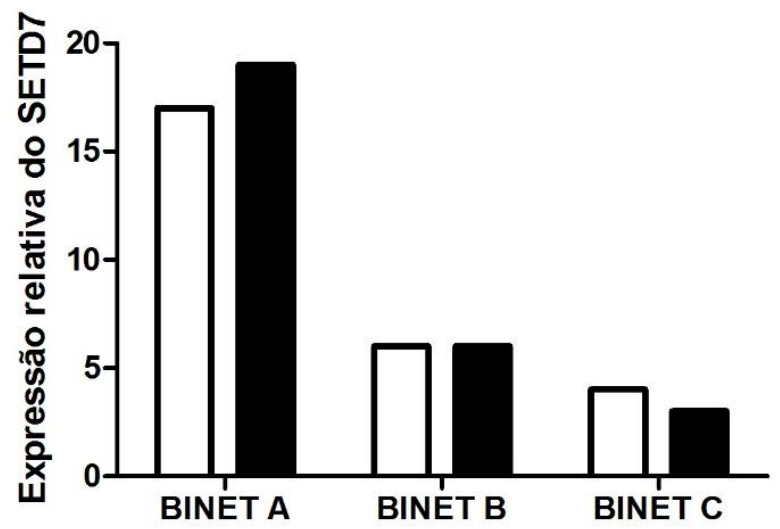

baixa expressão

alta expressão

Figura 58. Padrão de expressão relativa do gene SETD7 e estadiamento clínico de BINET, com $p=\mathbf{0 , 2 3 5 9}$ (teste Qui Quadrado com $p<0,05$ ).

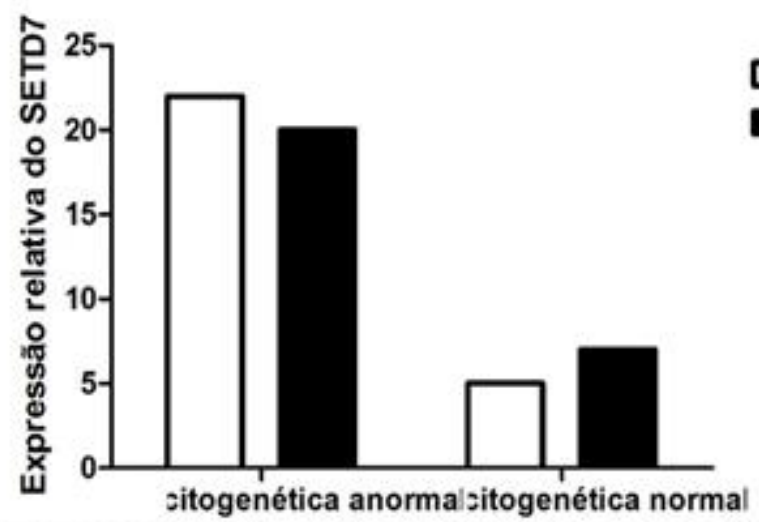

baixa expressão

alta expressão

Figura 59. Padrăo de expressão relativa do gene SETD7 e anormalidades citogenéticas com

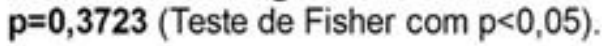


O gene supressor $p 53$, como discutido anteriormente, é metilado em linhagens celulares de câncer pela SETD7 e outra metiltransferase a SMYD2. O p53 funciona em grande parte por meio da ativação de genes alvo e os seus efeitos celulares incluem parada do ciclo celular, apoptose, senescência celular, diferenciação e reparo do DNA. Em linhas celulares de tumor, SET7 / 9 (também chamado SETD7 ou KMT7) foi mostrado ser responsável pela metilação da K372 do p53 humano, contribuindo assim para a sua estabilização e de ativação (134,135). No entanto, apesar de evidência de um papel crítico do gene SETD7 na metilação do p53 em resposta aos reparos do DNA, a relevância desta modificação e de outras modificações póstradução de p53 na leucemogênese ainda parece em aberto e até momento sem citação bibliográfica.

Assim, não conseguimos estabelecer uma relação entre a expressão do gene SETD7 nas amostras de LLC e sua associação no padrão de metilação do p53 e sua ação supressora ocasionando defeitos no reparo do DNA com consequente proliferação celular leucêmica. No contexto terapêutico, os pacientes com mutações do TP53 estão associados a estádios mais avançados e quimiorrefratariedade.

\subsection{PADRÃO DE EXPRESSÃO GÊNICA DOSETD8 EM AMOSTRAS DE LLC.}

O padrão de expressão relativa do gene SETD8 está exposto abaixo. Nota-se que os pacientes portadores de LLC apresentam padrão de expressão semelhante em comparação com controles. As características clínicas e prognósticas previamente definidas foram comparadas ao padrão de expressão relativa do gene SETD8 divididos em dois grupos: baixa e alta expressão. Não foram encontrados achados significativamente estatísticos entre o padrão de expressão do gene e tais características.

O gene SETD8 não foi até momento citado na literatura com relação da tumoregênese linfóide (Figura 61). Realizou-se a correlação de Spearmann entre o geneSETD8 e SET7. Não evidenciamos nenhuma correlação quanto ao padrão de expressão do SETD8 e o gene citado (correlação de Spearmann com r=0,16 e $\mathrm{p}<0,0001)$. 
O padrão de expressão relativa do gene SETD8 está exposto nas figuras abaixo. Nota-se que os pacientes portadores de LLC não apresentaram significância estatística em comparação com controles, sendo $p=0,3004$ (Figura 60).

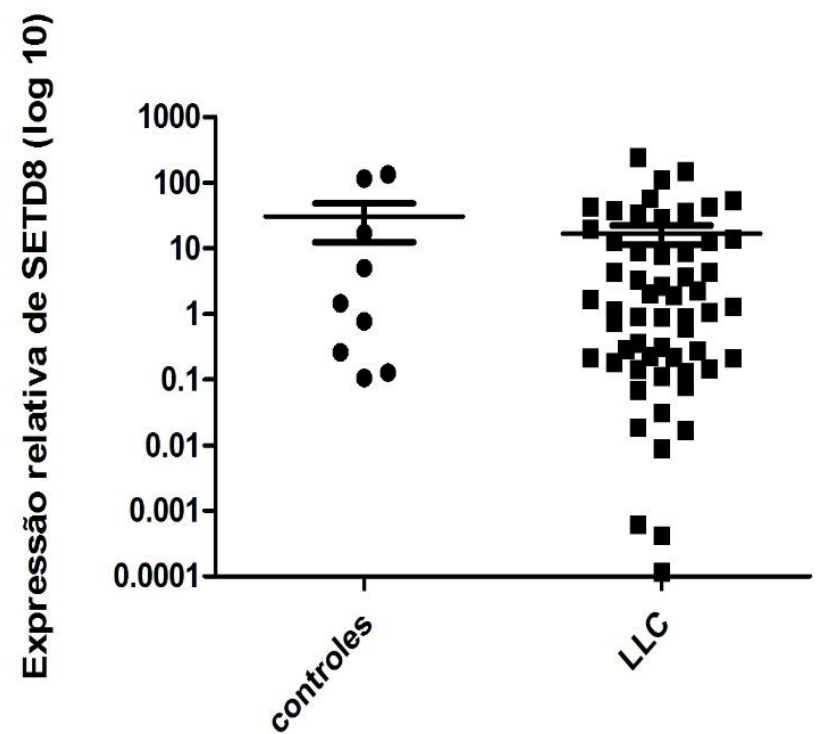

Figura 60. Padrão de expressão relativa do gene SETD8 entre amostras controles e pacientes com $p=0,3004$ (teste Mann Whitney com $p<0,05$ ).

As características clínicas e prognósticas previamente definidas e citadas (contagem leucocitária, contagem plaquetária, ZAP-70, estadiamento clínico de BINET e anormalidades citogenéticas) foram comparadas ao padrão de expressão relativa do gene SETD8 divididos em dois grupos: baixa e alta expressão.

O cutt off=1,12 foi utilizado para dividir os pacientes em dois grupos de expressão relativa do SETD8. Não foram encontrados achados significativamente estatísticos entre o padrão de expressão do gene e tais características clínicas. 


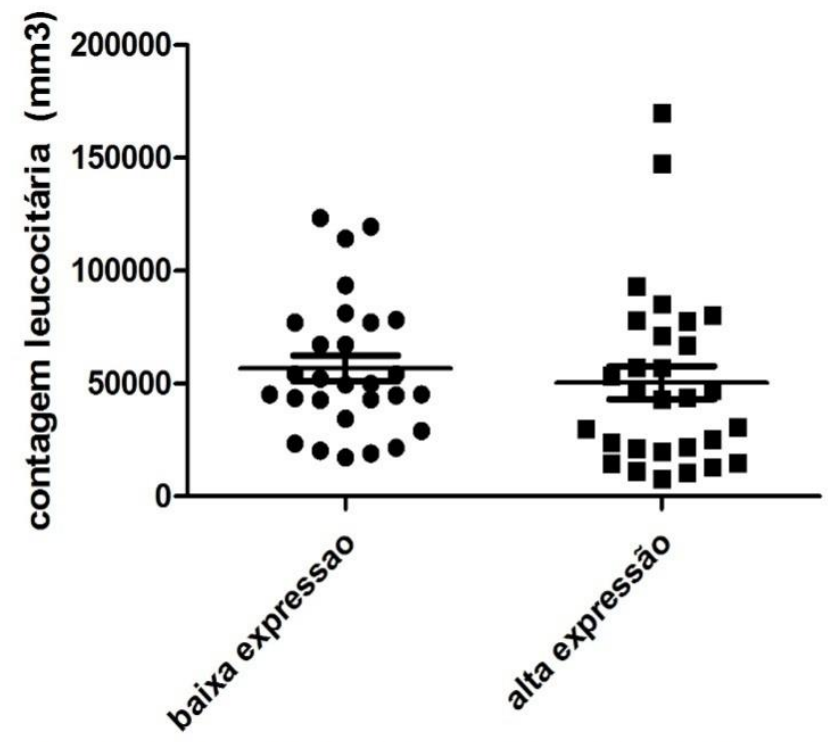

Figura 61. Padrão de expressão relativa do gene SETD8 e contagem leucocitária com $\mathrm{p}=\mathbf{0 , 1 3 5 4}$ (Teste Mann Whitney com $\mathrm{p}<0,05)$.

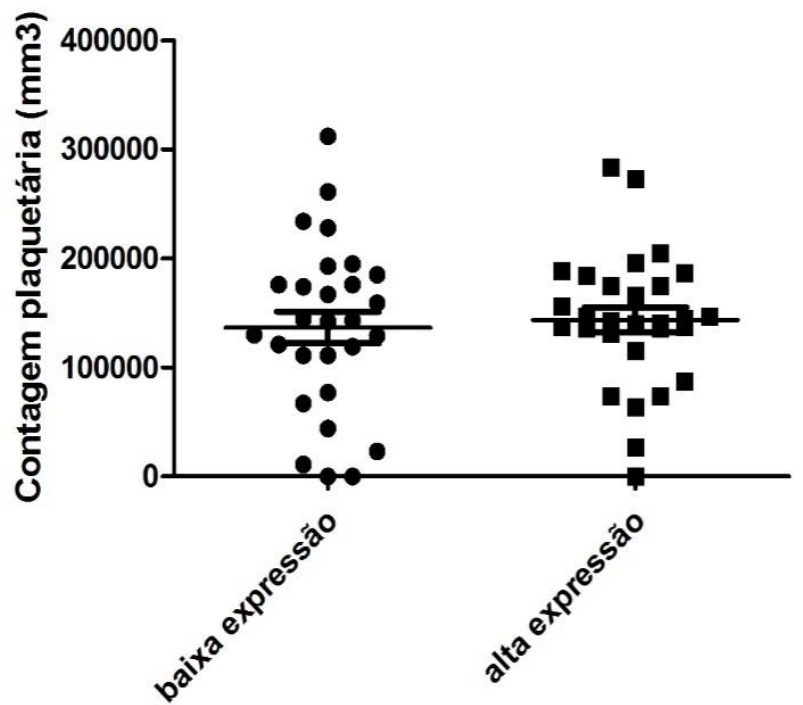

Figura 62. Padrão de expressão relativa do gene SETD8 e contagem plaquetária, com $p=$ 0,3568 (teste Mann Whitney com $p<0,05$ ). 


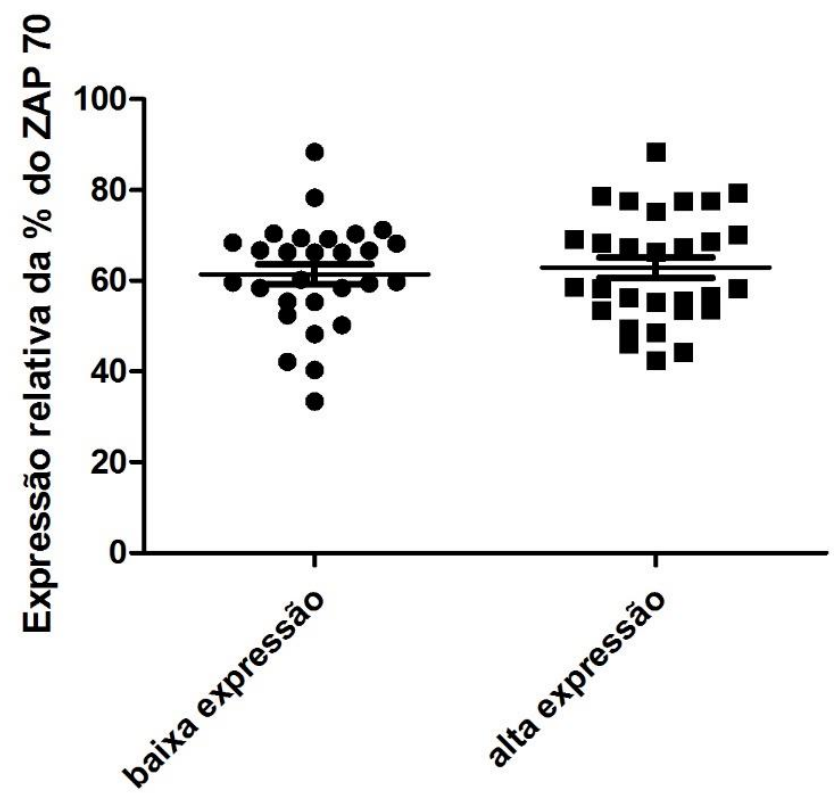

Figura 63. Padrão de expressão relativa do gene SETD8 e expressão do ZAP-70, com $\mathrm{p}=\mathbf{0 , 4 2 4 0}$ (teste Mann Whitney com $p<0,05$ ).

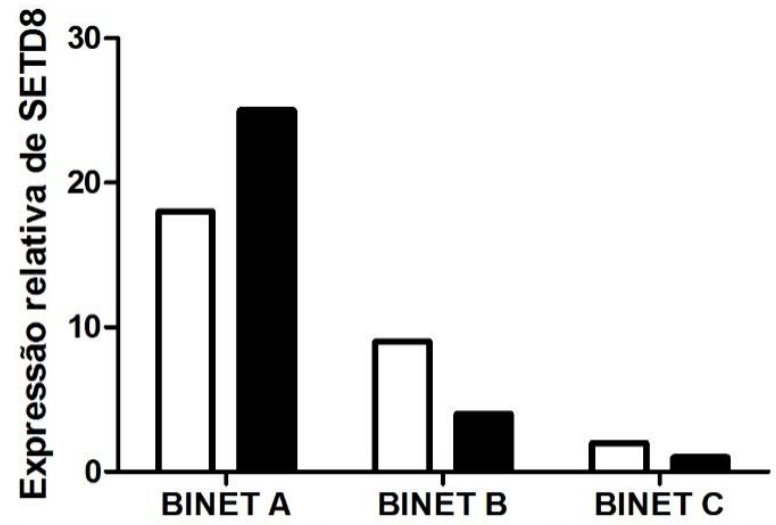

Figura 64. Padrão de expressão relativa do gene SETD8 e estadiamento clínico de BINET, com $\mathbf{p}=\mathbf{0 , 1 8 4 5}$ (Teste Qui-quadrado com $p<0,05$ ).

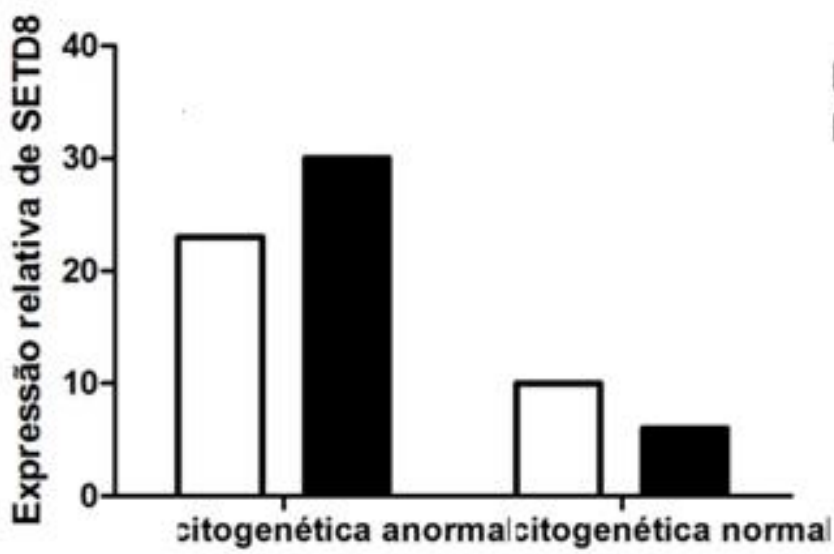

Figura 65. Padrão de expressão relativa do gene SETD8 e presença de anormalidades citogenéticas, com $p=0,14$ (teste Fisher $\operatorname{com} p<0,05$ ). 
O gene SETD8 não foi até momento citado na literatura com relação da tumoregênese linfóide (Figura 61). Não evidenciamos nenhuma correlação quanto ao padrão de expressão do SETD8 e gene SETD7 (correlação de Spearmann com r=0,16 e $p<0,0001$ ).

Em estudo recente (114), verificou-se que o gene SETD8 é superexpresso em várias linhagens celulares de câncer e, entre outros, regula as funções da proteina PCNA (antígeno de proliferação celular nuclear) através da metilação da lisina 248 . 0 PCNA interage com vários parceiros, incluindo proteínas envolvidas no reparo do DNA, síntese de DNA, metilação do DNA, remodelação da cromatina e regulação do ciclo celular. A proteína PCNA está superexpressa de forma estável em vários tipos de células cancerosas, em conjunto com SETD8, indicando que a metilação SETD8dependente de PCNA aumenta a sua atividade biológica. Knockdown de SETD8 suprimiu significativamente o crescimento de células cancerosas por diminuição da metilação em PCNA e redução dos seus níveis de expressão. Foi relatado recentemente que knockdown de SETD8 conduz a vários fenótipos aberrantes, incluindo dano no DNA, parada da divisão celular na fase $S$ e condensação cromossômica (132). De acordo com nossos resultados, não há diferença entre a expressão de SETD8 em células sanguineas monoclueares normais ou leucêmicas de LLC. Dessa forma concluímos que a SETD8 não contribui diretamente para a leucemogênese da LLC.

\subsection{PADRÃO DE EXPRESSÃO GÊNICA DO SETMAR EM AMOSTRAS DE LLC.}

O padrão de expressão do gene SETMAR em pacientes portadores de LLC comparado com amostras controles, evidenciam que o gene SETMAR está superexpresso nos pacientes com LLC quando comparado com amostras controles sendo $p=0,0014$ (Teste de Mann Whitney onde $p<0,05$ ) (Figura 66). 


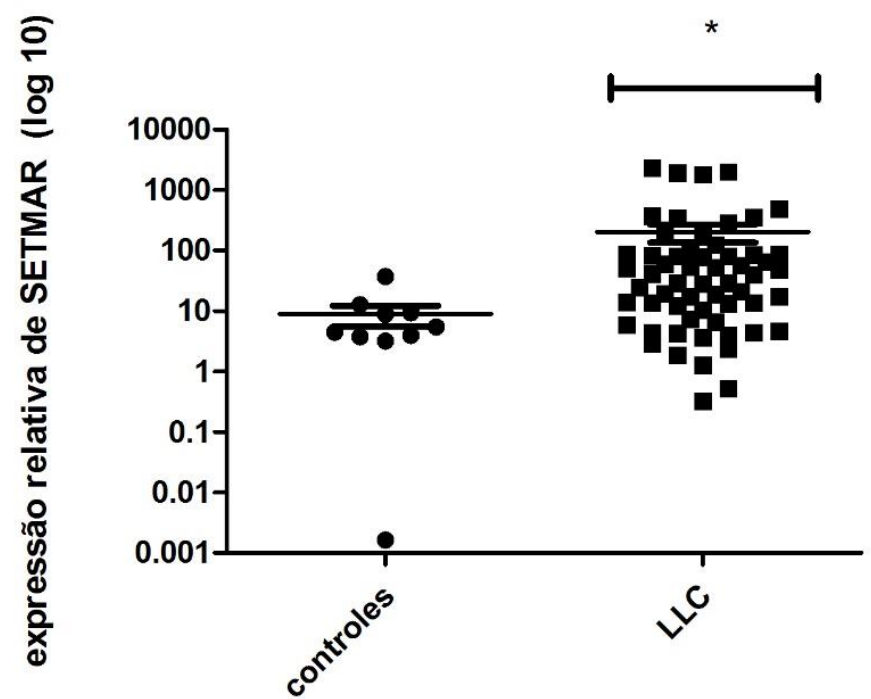

Figura 66. Expressão relativa do SETMAR entre as amostras controle e pacientes com LLC, com $\mathrm{p}=\mathbf{0 , 0 0 1 4}$ (teste de Mann Whitney $\mathrm{p}<0,05$ ).

A análise da expressão do gene SETMAR nos grupos de baixa e alta expressão (sendo o cutt off=29,37 para divisão dos grupos) quanto a contagem leucocitária, demonstrou que o silenciamento do gene SETMAR está relacionado a uma elevada contagem leucocitária (massa tumoral), com $p<0,0050$ (teste de Mann Whitney sendo $\mathrm{p}<0,05)$ (Figura 67).

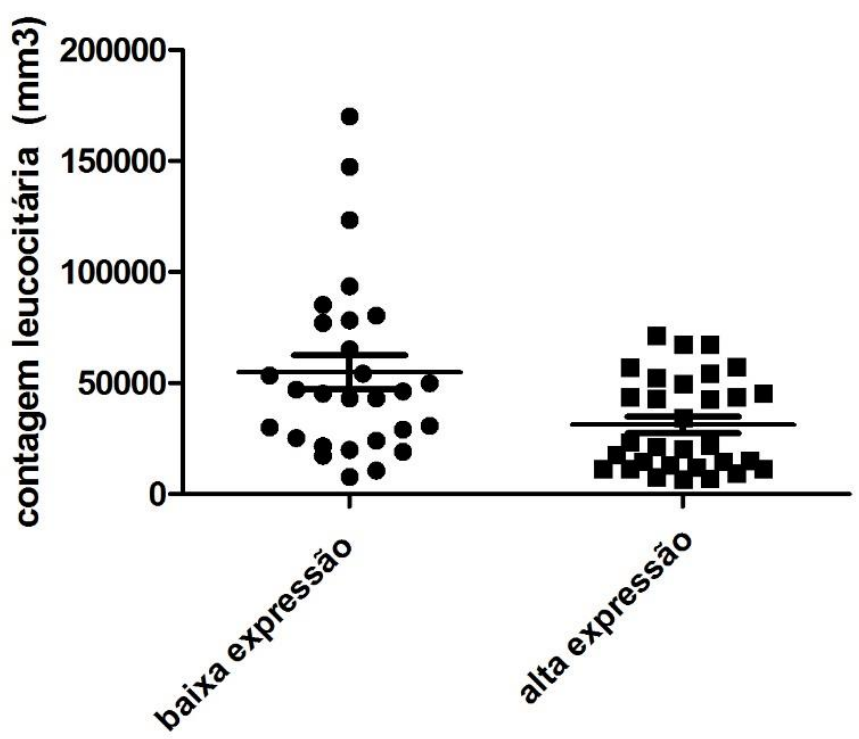

Figura 67. Padrão de expressão relativa do gene SETMAR e contagem leucocitária com $\mathbf{p}=\mathbf{0 , 0 0 5 0}$ (Teste de Mann Whitney com $\mathrm{p}<0,05$ ).

O grupo de baixa expressão relativa do gene SETMAR apresentou uma baixa contagem plaquetária com $\mathrm{p}=0,04$ (Figura 68) com significância estatística e corroborando os achados anteriores, onde os portadores de LLC numa fase mais 
avançada apresentam elevadas contagens leucocitárias e baixa contagem de plaquetas como sinal de progressão tumoral e infiltração de medula óssea (hematopoese ineficaz).

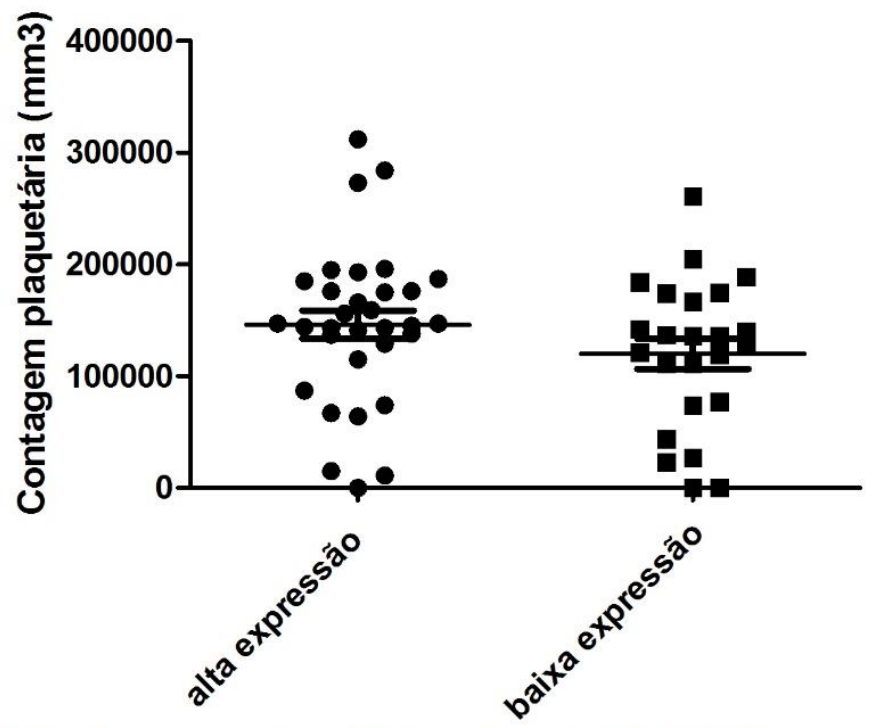

Figura 68. Padrão de expressão relativa do gene SETMAR e contagem plaquetária com $\mathrm{p}=\mathbf{0 , 0 4 8 9}$ (Teste de Mann Whitney com $\mathrm{p}<0,05)$.

A expressão do ZAP-70 (Figura 69) não apresentou significância estatística sendo $p=0,28$ (teste de Mann Whitney com $p<0,05$ ).

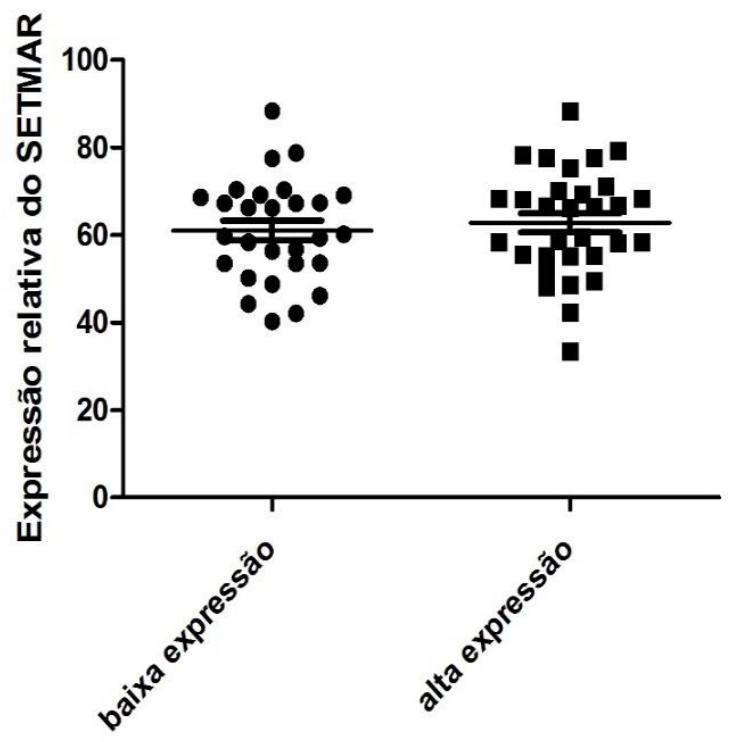

Figura 69. Padrão de expressão relativa do gene SETMAR e expressão de ZAP-70 sendo $p=0,28$ (teste de Mann Whitney $p<0,05$ ).

Outro achado interessante, foi que o grupo de baixa expressão do gene SETMAR apresentou uma elevada taxa de anormalidades citogenéticas $(p=0,020)$ 
(Figura 70), o que condiz com os achados anteriores (contagem leucocitária e contagem plaquetária) de que o silenciamento do gene SETMAR esteja relacionado a progressão da LLC, mediante instabilidade cromossômica. Houve predominância da hiperploidia ( $\mathrm{n}=18$ casos).

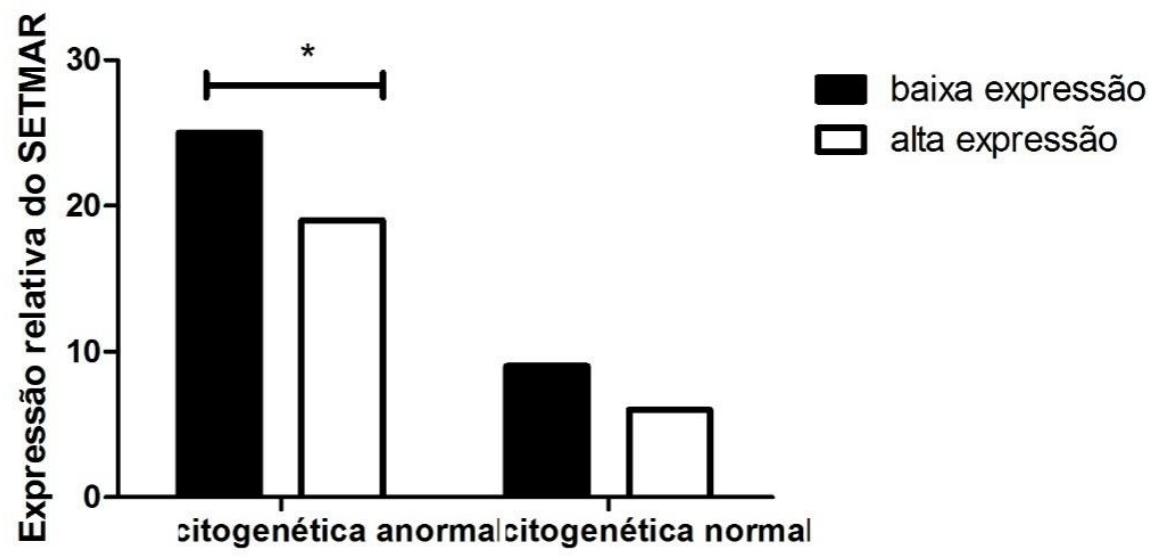

Figura 70. Padrão de expressão relativa do gene SETMAR e anormalidades citogenéticas com $\mathrm{p}=\mathbf{0 , 0 3 0}$ (Teste de Fisher, sendo $\mathrm{p}<0,05$ ).

O estadiamento clínico de BINET (Figura 71) não apresentou relevância estatística quanto ao padrão de expressão do gene SETMAR sendo $p=0,70(p<0.05)$.

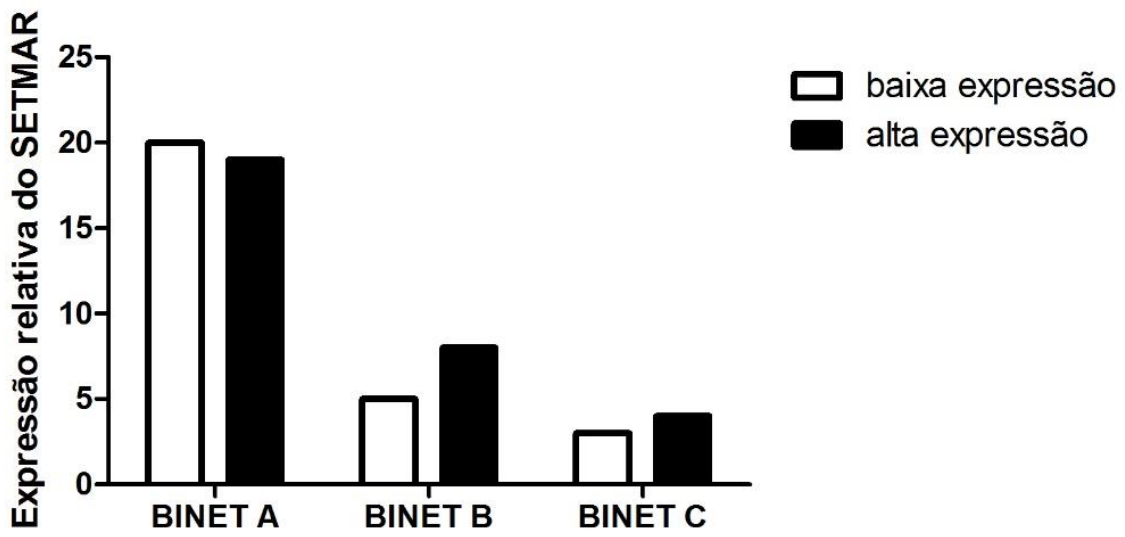

Figura 71. Padrão de expressão relativa do gene SETMAR e estadiamento clínico de BINET com $\mathbf{p}=\mathbf{0 , 0 7 1 1}$ (teste de Qui-Quadrado sendo $p<0,05$ ).

O gene SETMAR já foi citado em estudos com neoplasias mielóide agudas e tumores sólidos, porém é primeira vez de sua análise em amostras LLC e ainda não está bem definido como age este gene nesta neoplasia linfóide.

Em nosso estudo, a hipoexpressão do gene SETMAR em pacientes com LLC está relacionada com predominância de anormalidades cromossômicas, inferindo que a baixa expressão eliminaria um efeito protetor contra a instabilidade cromossômica. 
Esse achado pode ser corroborado pela presença elevada das alterações ciogenéticas descritas como hiperploidia. A hiperploidia significa a detecção de no mínimo 47cromossomos. Esse achado é freqüente nas neoplasias hematológicas (principalmente LLA e LMA) (2). Seu significado na LLC não esta definido, porém na maioria das neoplasias hematológicas do adulto (LMA e tumores sólidos imaturos e germinativos) denotam em péssimo prognóstico clínico e uma pronunciada resistência aos tratamentos quimioterápicos, principalmente aos antracíclicos e inibidores da topoisomerase (etoposide) (2). Na infância, a hiperploidia está relacionada ao bom prognóstico das LLA. Lembramos que os antracíclicos (como daunorribicina e mitoxantrona) e etoposide são drogas comumente utilizadas nos tratamentos das leucemias agudas e nos tumores sólidos. Sugerimos que abaixa expressão do gene em SETMAR em amostras de LLC pode causar instabilidade cromossômica contribuindo para quebras duplas de DNA.

Sabe-se que as instabilidades cromossômicas predispõem a resistência de algumas células aos quimioterápicos (antraciclicos e inibidores da topoisomerase II) e radiação ionizantes (135). Assim, sugerimos que o silenciamento do SETMAR em amostras de LLC, além de contribuir para instabilidade cromossômica, poderia induzir um aumento na resistênciadas células leucêmicas aos antraciclicos e inibidores da topoisomerase II, sugerindo o direcionamento terapêutico especifico para tratamento da LLC onde o SETMAR estivesse silenciado. 


\section{DISCUSSÃO}

A leucemia linfocítica crônica (LLC) é uma das neoplasias linfóides crônicas mais comuns na população ocidental e com os investimentos terapêuticos atuais e asdescobertas na sua patogênese (devido aos novos reguladores celulares e moleculares) está ganhando cada vez mais ênfase no estudo da sua biologia e terapêutica $(2,5,6)$.

Regulação epigenética refere-se a alterações hereditárias e possivelmente reversíveis na expressão fenotípica do genoma, que alteram a expressão de genes sem afetar na sequência do DNA $(38,41)$. Na vasta gama de mecanismos epigeneticos estão incluídos a metilação do DNA, modificações em histonas, remodeladores da cromatina e RNA não codantes, que estão implicados na ativação de oncogenes, na perda da função de supressão tumoral e na perda de imprinting (42). A epigenética orquestra vários procedimentos fisiológicos (transcrição, replicação, reparação) de desenvolvimento até os estágios diferenciados e possue um papel fundamental na biologia tumoral. Aberrações genéticas e epigenéticas estão envolvidas em uma rede complexa e tanto podem predispor ou causar o desenvolvimento de células tumorais.

Atualmente, o interesse no estudo dos mecanismos epigenéticos da LLC, tivemos os questionamentos se a família SETD estaria envolvida na leucemogênese dos pacientes com LLC. Assim o presente trabalho avaliou o perfil de expressão da família SETD em amostras de pacientes portadores de LLC.

O padrão de expressão do gene SETD1A nas amostras de LLC pode agir na via WNT. Em determinados tecidos/órgãos, é sabido que a proteína $\beta$-catenina constitui não somente um componente estrutural das junções de adesão, mas também é uma molécula sinalizadora juntamente com a $W N T$, participando de vários processos celulares, tais como diferenciação e proliferação(126). Assim, o gene SETD1A em amostras de LLC poderia interagir na via WNT aumentando grau de proliferação das células leucêmicas.

Assim, podemos hipotetizar que a hipoexpressão do SETD1Apode: a) desregular a via $W N T$, intereferindo na diferenciação das células B gerando proliferação 
acelerada, via $\beta$ catenina; b) contribuir para instabilidade cromossômica como o gene $M L L$ e assim perpetuar a proliferação celular.

Sabe-se que ação enzimática de trimetilação da lisina 36 da histona H3, efetuada pela SETD2 é necessária para reparo do DNA e a estabilidade genômica, o que condiz com as amostras de tumores sólidos deficientes em SETD2 exibirem uma ampla variedade de mutações, incluindo inserções, deleções e aberrações cromossômicas (103). Esses relatos associados com nossos novos achados inferem duas sitações: a) a expressão do gene SETD2 é diferente no seu padrão de expressão nos diferentes cânceres, principalmente na leucemogênese; b) a hiperexpressão desse gene em amostras de LLC está relacionada com maior massa tumoral, isto é, maior proliferação celular, ao contrário dos tumores sólidos como: cólon e mama (citados anteriormente), onde o silenciamento do gene SETD2 age como marcador de progressão da doença oncológica.

O gene SETD5 ainda não possui dados na literatura que o relacione com qualquer tipo de carcinogênese. Apesar de não termos achado diferença na expressão global entre os grupos controle e de LLC, demonstramos que os pacientes portadores de LLC com baixa expressão, a contagem leucocitária foi mais elevada do que no grupo com alta expressão, sendo $p=0,0013(p<0,05)$. Os pacientes com baixa expressão do gene apresentaram uma elevada quantidade de anormalidades citogenética, sendo $p=0,036(p<0,05)$. Como seu papel como um oncogene ainda não está bem estabelecido, realizamos uma consulta aos bancos de dados disponíveis de pesquisas genéticas sobre antecedentes de descrição desse gene em linhagens celulares oncológicas. Só encontramos descrição deste gene e seu padrão de expressão em linhagens de osteossarcoma e células de carcinomas epidermóides (The Human Protein Atlas, 2014). Este é,talvez, o primeiro trabalho de descrição desse gene em amostras de LLC e que diante dos achados o SETD5 poderia estar atuando como oncogene. Os resultados do padrão de expressão relativa do gene SETD5 são muito promissores principalmente na elucidação da via de ação da proliferação das células leucêmicas de linhagem B e na verificação dos mecanismos da instabilidade cromossômicas.

O gene SETD6 apresentou-se hipoexpresso nas amostras de LLC em relação aos controles com significância estatística $(p=0,0244)$. Conforme citamos anteriormente, 
este gene já foi citado atuando na via do $N F-k \beta$. Sabe-se que a inibição do $N F-k B$ leva a uma diminuição da expressão das moléculas de adesão e de vários fatores de proliferação, sobrevida e angiogênicos (109). Embora sejam doenças biologicamente diferentes, grande parte do tratamento do mieloma múltiplo age na inibição da via NF$k \beta$, citamos a talidomida (efeito angiogênico) e os inibidores de proteassoma (bortezomib) (2). Esses medicamentos agem na inibição desta via e consequentemente diminuição da poliferação das células plasmocitárias. Assim, os resultados do gene SETD6 são muito promissores e devem ser elucidados qual sua relação com via $N F-k \beta$, pois poderíamos identificar moléculas alvo agindo na inibição do SETD6 com consequentemente inibição da via $N F-k \beta$, resultando na morte das células leucêmicas.

O gene de fusão de transposase Mariner (SETMAR), também conhecido como Metnase, anteriormente foi citado como gene supressor das translocações cromossômicas em fibroblastos de rato.Já foram identificadas seis variantes de transcrição (var1, var2, var5, $\operatorname{Var} A$, varB, $\operatorname{var} C$ ) do gene SETMAR.

O padrão de expressão do gene SETMAR já foi estudado em neoplasias mielóides agudas (LMA) sendo verificado que a sua superexpressão seja mais frequente nos portadores de LMA do que nos controles normais (células progenitoras hematopoéticas normais) e a superexpressão deste gene possa estar relacionada a prevenção das anormalidades citogenéticas (118). Nas neoplasias de mama, o silenciamento da expressão do SETMAR pode ocasionar melhora da ação dos antracíclicos (inibidores da topoisomerase II) no tratamento adjuvante (136). Além disso, os níveis de Metnase parecem ter impacto na apoptose nas células de câncer de cólon (137).

O gene SETMAR está envolvido em decatenação como causa de rupturas de filamentos duplos podendo assim resultar em anormalidades cromossômicas. No entanto, desconhece-se sobre o mecanismo bioquímico deste decatenação (116).

Sabe-se que o gene SETMAR age no aumento na junção final não homologa (NHEJ) durante reparo da ruptura da fita dupla do DNA, aumenta decatenação cromossômica contra topoisomerase II (118). A maioria das translocações cromossômicas oncológicas resultam de NHEJ como principal mecanismo (116). Diante dos dados descritos neste trabalho, sugerimos que a baixa expressão do gene 
SETMAR pode levar a perda do efeito protetor contra instabilidade cromossômica das células da LLC, diminuição da NEHJ e aumento da resistência da enzima topoisomerase II e a antraciclina (quimioterápicos utilizados no tratamento da LLC). Fenômeno este já observado na LMA, porém ainda desconhecido na LLC. A presença de hiperploidia reforça a instabilidade cromossômica como um fenômeno de contantes quebras e repados na fita do DNA. Resumidamente, sugerimos que o gene SETMAR possui ação de oncogene em células de LLC.

As plataformas The Human Protein Atlas, Cbioportal, Oncomine e Broadinstitute foram utilizadas para avaliar o padrão de expressão dos genes da família SETD em imunohistoquimica in silico, pesquisas em RNA, tipos de câncer e padrão de expressão da proteína. Porém, só encontramos citação de 3 genes em céuluas de LLC no The Human Protein Atlas (SETD1A, SETD1B e SETD2). Os achados quanto ao score de expressão protéica dos genes citados na linha acima, condizem como nossos achados: menor expressão proteica dos genes SETD1A e SETD1B e supreexressão gene SETD2. Os resultados da análise imunohistoquimica via plataforma in silico nos sugerem a necessidade de adentrarmos no campo proteico e avaliar como se comportam essas proteínas transcritas pelos nossos genes de interesse nas próprias amostras dos pacientes estudados. Assim, teríamos a possibilidade de um controle refinado sobre os níveis de RNA e proteínas correlacionados com dados clínicos dos pacientes.

Não identificamos associação de expressão de nenhum dos genes da família SETD com ZAP-70, proteína esta já citada como associada expressão da imunoglobulina de cadea leve não mutada e considerada como um marcador de pior evolução clinica dos portadores de LLC. Talvez isso se deva ao número de amostras insuficiente para evidenciarmossinais de relevância estatística ou se os componentes da família SETD não agem na expressão da cadeia de imunoglobulina. A pesquisa da mutação da cadeia pesada da imunglobulina deve ser realizada ao diagnóstico e durante $o$ tratamento, principalmente nos casos de resposta terapêutica insuficiente ou progressão da doença.

Neste trabalho, não conseguimos identificar relação estatística entre a expressão relativa dos genes da família SETD e sinalização dos receptores de células B, pontochave para o entendimento desta complexa sinalização das células $B$ e intervenções 
terapêuticas. Estudos futuros devem responder se alterações no padrão de expressão dos genes da família SETD conferem pior evolução clínica e consequente estadimento de BINET. Lembramos que o estadiamento clínico de BINET é alterado subseqüente ao longo do curso da doença, assim no momento em que as amostras de LLC foram coletadas os pacientes possuíam o estadiamento determinado. Ao longo do curso da doença, várias características clínicas e moleculares são alteradas, incluindo BINET. Assim, a expressão dos genes da família SET pode estar alterado se pesquisada nas fases mais avançadas.

As 59 amostras clínicas de portadores de LLC apresentam-se bastante heterogêneas quanto aos seus padrões de expressões gênicas e suas variáveis clinicas. Acreditamos que esforços futuros serão necessários para captar um maior número de amostras clinicas de portadores de LLC para podermos obter várias respostas a questionamentos que surgiram como: impacto na sobrevida de acordo com padrão de expressão, sua expressão in silico, atividade transcricional, correlação com terapêutica oncológica instituída e com curso evolutivo da doença. 


\section{CONCLUSÃO}

Os dados obtidos em nosso trabalho sugerem que diferentes genes codificadores de metiltransferase estão diferencialmente expressos nas células de leucemia linfocítica crônica (LLC) e sugerem interferência nas variáveis clinicas estudadas, evidenciando a importância do estudo desta classe de genes para compreensão da origem e manutenção desta neoplasia linfóide B madura.

O gene SETD1A pode estar relacionado a instabilidade cromossômica e atuar na progressão das células B em portadores de LLC.

A contagem leucocitária elevada no grupo de alta expressão do gene SETD2 pode estar relacionado com progressão da LLC e aumento da massa tumoral.

Sugere-se que o gene SETD5 atue como um marcador de progressão da doença devido a elevada contagem de leucócitos nos pacientes do grupo de baixa expressão associado a predominância das anormalidades citogenéticas, sendo achados promissores no estudo da LLC.

O gene SETD6 apresentou hipoexpresso nos portadores de LLC em relação aos controles, sendo inédito sua descrição na literatura em neoplasias linfoides $B$, mesmo apresentando vasta associação do gene SETD6 com via NF-KB. Futuramente, esses achados deverão ser melhores explorados e analisados da ação do SETD6.

O gene SETMAR apresentou-se hiperexpresso nos portadores de LLC em relação aos controles. A contagem leucocitária foi elevada no grupo de pacientes com baixa expressão, bem como a predominância de anormalidades citogenéticas.Sugerimos que nos portadores de LLC, a perda de expressão do SETMAR esteja associada com instabilidade cromossômica e progressão da massa tumoral (aumento da leucocitose). Novos estudos devem ser realizados com finalidade de evidenciar se a repressão do gene SETMAR seja uma alteração característica das fases iniciais da LLC como marcador de mal prognóstico ou adquirido ao longo do tratamento. 


\section{REFERÊNCIAS BIBLIOGRÁFICAS}

1. Cheson BD, Bennett JM, Grever M, Kay N, Keating MJ, O'Brien S, Rai KR. Chronic lymphocytic leukemia: revised guidelines for diagnosis and treatment. Blood. 1996 ; 87 (12) : 4990-4997.

2. Zago MA, Passeto R, Pasquini R. tratado de hematologia. Editor Atheneu 2014 , paginas 451.

3. National Cancer Institute. SEER Stat Fact Sheets: Chronic Lymphocytic Leukemia. http:// seer.cancer.gov/statfacts/html/clyl.html. Accessed November 11, 2009.

4. Rossi D, Rasi S, Spina V, Bruscaggin A, Monti S et al. Integrated mutational and cytogenetic analysis identifies new prognostic subgroups in chronic lymphocytic leucemia. Blood. 2013;121(8): 3249-3360.

5. Hallek M, Cheson BD, Catovsky D, et al. Guidelines for the diagnosis and treatment of chronic lymphocytic leukemia: a report from the International Workshop on Chronic Lymphocytic Leukemia updating the National Cancer Institute-Working Group 1996 guidelines. Blood. 2008;111(12):5446-5456.

6. Binet J, Caligaris-Cappio F, Daniel Catovsky, Bruce Cheson, Tom Davis, Guillaume Dighiero, Hartmut Do“hner, Michael Hallek, Peter Hillmen, Michael Keating, Emili Montserrat, Thomas J. Kipps, and Kanti Rai, for the International Workshop on Chronic Lymphocytic Leukemia (IWCLL)-initiated working group on prognostic and diagnostic parameters in CLL. Perspectives on the use of new diagnostic tools in the treatment of chronic lymphocytic leucemia. Blood. 2006: 107 (3): 1200-1210.

7. Matutes E, Owusu-Ankomah K, Morilla R, Garcia Marco J, Houlihan A, Que $\mathrm{TH}$, Catovsky D. The immunological profile of B-cell disorders and proposal of a scoring system for the diagnosis of CLL. Leukemia : official journal of the Leukemia Society of America, Leukemia Research Fund, U.K. 1994 ; 8 (10) : 1640-1645.

8. Harris NL, Jaffe ES, Diebold J, et al. World Health Organization classification of neoplastic diseases of the hematopoietic and lymphoid tissues: report of the Clinical Advisory Committee meeting-Airlie House, Virginia, November 1997. J Clin Oncol. 2008;17(12):3835-3849. 
9. Do“hner H, Stilgenbauer S, Benner A, et al. Genomic aberrations and survival in chronic lymphocytic leukemia. N Engl J Med. 2000;343: 1910-1916.

10. Rai KR, Sawitsky A, Cronkite EP, Chanana AD, Levy RN, Pasternack BS. Clinical staging of chronic lymphocytic leukemia. Blood. 1975;46:219-234.

11. Binet JL, Auquier A, Dighiero G, et al. A new prognostic classification of chronic lymphocytic leucemia derived from a multivariate survival analysis. Cancer. 1981;48:198-204.

12. Dighiero G, Binet JL. When and How to treat chronic lymphocytic leukemia. NEJM 2000;343(24):1.799-801.

13. Rai KR. A critical analysis of staging in CLL. In: Gale RP, Rai KR, eds. Chronic Lymphocytic Leukemia:Recent Progress and Future Directions.New York, NY: Liss; 1987:253-264.

14. Montserrat E, Sanchez-Bisono J, Vinolas N, Rozman C. Lymphocyte doubling time in chronic lymphocytic leukaemia: analysis of its prognostic significance. $\mathrm{Br} \mathrm{J}$ Haematol. 1986;62:567-575.

15. Hamblin TJ, Orchard JA, Gardiner A, Oscier DG, Davis Z, Stevenson FK. Immunoglobulin V genes and CD38 expression in CLL. Blood. 2000;95: 2455-2457. 16. Damle RN, Wasil T, Fais $F$, et al. Ig V gene mutation status and CD38 expression as novel prognostic indicators in chronic lymphocytic leukemia. Blood. 1999;94:1840-1847.

17. Crespo M, Bosch F, Villamor N, et al. ZAP-70 expression as a surrogate for immunoglobulin-variable- region mutations in chronic lymphocytic leukemia. $\mathrm{N}$ Engl J Med. 2003;348:1764-1775.

18. Orchard JA, lbbotson RE, Davis Z, et al. ZAP-70 expression and prognosis in chronic lymphocytic leukaemia. Lancet. 2004;363:105-111.

19. Rassenti LZ, Huynh L, Toy TL, et al. ZAP-70 compared with immunoglobulin heavy-chain gene mutation status as a predictor of disease progression in chronic lymphocytic leukemia. N Engl J Med. 2004;351:893-901.

20. Vasconcelos Y. Marcadores prognósticos da leucemia linfocítica crônica. Ver.Brasil.Hem.Hemote.2005;27(4):253-262.

21. Keating MJ LS, Kantarjian H, Freireich EJ, O'Brien S. The serum _2microglobulin ( $2 \mathrm{~m}$ ) level is more powerful than stage in predicting response and survival in chronic lymphocytic leucemia (CLL) [abstract]. Blood. 1995;86:606a. 
22. Hallek M, Wanders L, Ostwald M, et al. Serum beta(2)-microglobulin and serum thymidine kinase are independent predictors of progressionfree survival in chronic lymphocytic leukemia and immunocytoma. Leuk Lymphoma. 1996;22:439447.

23. Ibrahim $\mathrm{S}$, Keating $\mathrm{M}$, Do KA, et al. CD38 expression as an important prognostic factor in B-cell chronic lymphocytic leukemia. Blood. 2001;98:181-186.

24. Rawstron AC, Bennett FL, O'Connor SJ, et al. Monoclonal B-cell lymphocytosis and chronic lymphocytic leukemia. N Engl J Med. 2008;359(6):575583.

25. Stilgenbauer S, Do" hner H. Campath-1H-induced complete remission of chronic lymphocytic leukemia despite p53 gene mutation and resistance to chemotherapy. N Engl J Med. 2002;347:452-453.

26. Lozanski G, Heerema NA, Flinn IW, et al. Alemtuzumab is an effective therapy for chronic lymphocytic leukemia with p53 mutations and deletions. Blood. 2004;103:3278-3281.

27. Grever MR, Lucas DM, Dewald GW, et al. Comprehensiv eassessment of genetic and molecularfeatures predicting outcome in patients with chronic lymphocytic leukemia: results from the US Intergroup Phase III Trial E2997. J Clin Oncol. 2007;25:799-804.

28. Hamblin TJ, Orchard JA, Ibbotson RE, et al. CD38 expression and immunoglobulin variable region mutations are independent prognostic variables in chronic lymphocytic leukemia, but CD38 expression may vary during the course of the disease. Blood. 2002;99(3):1023-1029.

29. Rosenwald A, Alizadeh AA, Widhopf G, Simon R, Davis RE, et al. Relation of gene expression phenotype to immunoglobulin mutation genotype in $B$ cell chronic lymphocytic leukemia. J Exp Med. 2001 Dec 3;194(11):1639-47.

30. Chen L, Widhopf G, Huynh L, et al. Expression of ZAP-70 is associated with increased B-cell receptor signaling in chronic lymphocytic leukemia. Blood. 2002;100(13):4609-4614.

31. Howlader N, Noone AM, Krapcho M, et al; National Cancer Institute.CLL 2015. http://seer.cancer.gov (last accessed 28 January 2015).

32. Gribben JG. Molecular profiling in CLL. Hematology Am Soc Hematol Educ Program. 2008;8: 444-449. 
33. Lesley-Ann S, Rosenquis R. Deciphering the molecular landscape in chronic lymphocytic leukemia: time frame of disease evolution. Haematologica. 2015; 100(1): 3456-3463.

34. Oscier,D., Wade,R., Davis,Z., Morilla,A., Best,G., Richards,S., Else,M., Matutes,E., \& Catovsky,D. Prognostic factors identified three risk groups in the LRF CLL4 trial, independent of treatment allocation. Haematologica. 2010; 95: 17051712.

35. Rabello D, Lucena-Araujo R, Alves-Silva J, Eira V, Vasconcellos MC et al Overexpression of EZH2 associates with a poor prognosis in chronic lymphocytic leucemia. Blood cells, molecules \& diseases. 2015; 54(1): 97-102.

36. Neel K. Gupta, MD, Charalambos A. New Meets Old: A Case Study and Review of Novel Therapeutics for the Treatment of CLL in Older Patients. Journal of the National Comprehensive Cancer Network . 2014(12):10- 23.

37. Jeffrey A, Ones J, Byr C. How will B-cell-receptor-targeted therapies change future CLL therapy? Blood. 2014; 123: 562-572.

38. Muller, H.R. \& Prado, K.B. Epigenética: um novo campo da genética. RUBS. 2008; 1(3): 61-69.

39. Jenuwein, T; Allis, C.D. Translating the histone code. Science. 2001; 293 (5532): 1074-1080.

40. Thompson, E. Travers, AA. Drosophila Smyd4 homologue is a muscle-specific transcripttional modulator involved in development. Plos One. 2009; v.3, n.8, pe 3008.

41. Hamon, M.; Cossart, P. Histone modifications and Chromatin Remodeling during Bacterial infections. Cell Host and Microbe. 2008; 4 (2): 100-1009.

42. Wolfe, A.P.; Guschin, D.Review: chromatin strutural features and targets that regulate transcriptioon. Jornal of strutural Biology, 2000; 129(2):102-122.

43. Ho, S.M.; Tang, W. Y. Epigenetic reprogramming and imprinting in origins of disease. Rev Endocr Metab Disord. 2007;2(8):173-182.

44. Feinberg, A.P. Cancer epigenetics takes center stage. Proceedings of the National Academy of Science of the United States of America, 2001; 98(2):392-394.

45. Ducasse, M.; Brown M.A. Epigenetics aberrations and cancer. Mol Cancer. 2006; 8 (5) :60- 74.

46. Strahl B.D.; Allis, C.D.; The language of covalent histone modification.Nature.2000;43: 41-45. 
47. Peltomaki, P. Mutatios and epimutations in the origin of cancer. Experimental cell research, 2012; 318(4):299-310.

48. Varier, R.A.; Timmers, H.T.; Histone lysine methylation and demethylation pathways in cancer. Biochimia et biophysica acta, 2011; 1815(1):75-89.

49. Gonzalo,V et al. Epigenética de câncer . Gastroenterológica y hepatológica,2008;31(4)267-308.

50. Sharma,S.; Kelly, T.K.; Jones, P.A.; epigenetics in cancer. Carcinogenesis, 2010; 31(1):27-36.

51. Bacarelli A.; Bollati, V. epigenetics and envirommental chemicals. Current opinion in pediatrics, 2009;21(2):243-251.

52. Lopez J. et al. The context and potencial of epigenetics in oncology. British journal of cancer, 2009; 100(4):571-577.

53. Albert, M.; Helin, K. Histone methyltransferases in cancer. Seminars in Cell \& Developmental Biology.2009; 1084-9521.

54. Fog, C.K. Jensen, K.T.; Lund, A. H.chromatin-modifying proteins in cancer. APMIS: Acta pathologica, microbiologica et immunologica scandinavica, 2007; 115(10):1060-1089.

55. Portela, A.; Esteller, M. Epigenetic modifications and human disease. Nature Biotechnology, 2010; 28(10):1057-1068.

56. Cedar, H. \& Bergman, Y. Linking DNA methylation and histone modification: patterns and paradigms. Nature Reviews Genetics. 2009; 10: 295-304.

57. Green, J.B. Shi, Y. histone methylation: a dynamic mark in health, disease and inheritance. Nature Reviews.genetics, 2012;139 (5):343-357.

58. Martin, C. Zhang, Y. The diverse functions of histone lysine methylation. Nature reviews. Molecular cell Biology,2005; 6(11):838-849.

59. Bannister, A.J. Kouzarides, T. regulation of chromatin by histone modifications. Cell Reseach,2011; 21(3):381-395.

60. Copeland, R. A., M. P. Moyer, et al.Targeting genetic alterations in protein methyltransferases for personalized cancer therapeutics. Oncogene. 2013; 32(8): 939946.

61. Huang, J. et al. G9a and Glp Methylate Lysine 373 in the Tumor Suppressor p53. The journal of biological chemistry.2010; 285 (13): 9636-9641. 
62. Lennartsson, A.; Ekwall, K. Histone modification patterns and epigenetics codes. Biochimica et biophysica acta (BBA)-general subjects, 2009; 1790 (9):863868.

63. Schuettengruber B; Chourrot D; Vervoot M. Genome Regulation by policomb proteins. Cell, 2007; 128(4): 735-745.

64. Cross, N.C.P. histone modification defects in developmental disorders and cancer. Oncotarget. 2012;3 (1):3-4.

65. Baylin, S.B. \& Ohm J.E. Epigenetic gene silencing in cancer: A mechanism for early oncogenic pathway addiction? Nature Reviews Cancer. 2006; 6: 107-116.

66. Rodrigues-Paredes,M. et al. Gene amplification of the histone methyltransferase SETD1B contribui to human lung tumorigenesis. Oncogene. 2014;33(21):2807-2813.

67. Dialynas, G. K.; vitalini, M. W.; Wallrath, L. L. Linking heterochromatin protein 1 (HP1) to cancer progression. Mutation Research. 2008, 647 (1/2): 13-20.

68. Esteller, M. Cancer Epigenomics: Dna Methylomes and Histone-Modification Maps. Nature reviews: Genetics. 2007; 8 (4): 286-298.

69. Fraga, M. F.; Ballestar, E.; villar-garea, A.; Boix-chornet, M.; Espada, J. et al. Loss of acetylation at Lys 16 and trimethylation at Lys 20 of histone $\mathrm{H} 4$ is a common hallmark of human cancer. Nature Genetics. 2005; 37(4): 391-400.

70. Moore, S. D.; Herrick ,S. R.; INCE, T. A.; Kleinman, M. S. et al. Uterine leiomyomata with $\mathrm{t}(10 ; 17)$ disrupt the histone acetyltransferase MORF. Cancer Research. 2004; 64: 5570-5577.

71. JIN, K. L.; Pak, J. H.; Park, J. Y.; CHOI, W. H.; LEE, J. Y.; et al. Expression profile of histone deacetylases 1,2 and 3 in ovarian cancer tissues. Journal of gynecologic oncology. 2008; 19, (3):185- 90.

72. Lehmann, A.; Denkert, C.; Budczies, J.; Buckendahl, A. C. et al. High class I HDAC activity and expression are associated with RelA/p65 activation in pancreatic cancer in vitro and in vivo. BMC Cancer. 2009; 9: 395- 410.

73. WANG, Y.; LEUNG, F. C. An evaluation of new criteria for CpG islands in the human genome as gene markers. Bioinformatics,2004; 20: 1170-1177.

74. KONDO, Y.; SHEN, L.; SUZUKI, S.; KUROKAWA, T. et al. Alterations of DNA methylation and histone modifications contribute to gene silencing in hepatocellular carcinomas. Hepatology Research. 2007; 37: 974-983. 
75. PARK, Y. S.; JIN, M. Y.; KIM, Y. J.; YOOK, J. H.; KIM, B. S. et al . The global histone modification pattern correlates with cancer recurrence and overall survival in gastric adenocarcinoma. Annals of surgical oncology, 2009; v.15(7): 968-1976.

76. Barlesi, J; Füllgrabe, J; Kavanagh, E; . Histone onco-modifications. Oncogene. 2013; 30 (4): 3391-3403.

77. Hamamoto, R.; Furukawa, Y.; Morita, M.; IImura, Y.; Silva FP. Et al . SMYD3 encodes a histone methyltransferase involved in the proliferation of cancer cells. Nat Cell Biol. 2004; 6: 31-740.

78. Hamamoto, R. et al. Enhance SMYD3 expression in essential for the prowth of breast cancer cells. Cancer Science. 2006; 97(2):113-118.

79. Bracken, H. Kloor, M. Pox, C. P. Epigenetic of colorrectal cancer. Lancet, 2014; 383(9927):1490-1502.

80. Saddic LA, West LE, Aslanian A, Yates JR 3rd, Rubin SM, Gozani O, Sage J (2010) Methylation of the retinoblastoma tumor suppressor by SMYD2. J Biol Chem. 2009; 285: 37733-37740.

81. Deaton, Aimée M., et al. "Cell type-specific DNA methylation at intragenic CpG islands in the immune system." Genome research. 2011: 1074-1086.

82. Ji, Hong, et al. "Comprehensive methylome map of lineage commitment from haematopoietic progenitors." Nature. 2010: 338-342.

83. Challen, Grant A., et al. "Dnmt3a is essential for hematopoietic stem cell differentiation." Nature genetics. 2012: 23-31.

84. Shakhnovich, E; Muyoung, H; Maslov, S. "Topology of protein interaction network shapes protein abundances and strengths of their functional and nonspecific interactions." Proceedings of the National Academy of Sciences. 2011: 4258-4263.

85. Amara, Khaled, et al. "DNA methyltransferase DNMT3b protein overexpression as a prognostic factor in patients with diffuse large B-cell lymphomas." Cancer Science.2010: 1722-1730.

86. Zhao, Fei, et al. "Role of triptolide in cell proliferation, cell cycle arrest, apoptosis and histone methylation in multiple myeloma U266 cells."European journal of pharmacology. 2010: 1-11.

87. Corcoran, Martin, et al. "ZAP-70 methylation status is associated with ZAP-70 expression status in chronic lymphocytic leukemia." Haematologica. 2005: 10781088. 
88. Cahill, Nicola, et al. "450K-array analysis of chronic lymphocytic leukemia cells reveals global DNA methylation to be relatively stable over time and similar in resting and proliferative compartments." Leukemia. 2013: 150-158.

89. Mabuchi, Hideaki, et al. "Cloning and characterization of CLLD6, CLLD7, and CLLD8, novel candidate genes for leukemogenesis at chromosome 13q14, a region commonly deleted in B-cell chronic lymphocytic leukemia." Cancer research. 2001: 2870-2877.

90. Pekarsky, Yuri, et al. "Tcl1 expression in chronic lymphocytic leukemia is regulated by miR-29 and miR-181." Cancer research 66.24 (2006): 11590-11593.

91. Calin, George Adrian, et al. "A MicroRNA signature associated with prognosis and progression in chronic lymphocytic leukemia." New England Journal of Medicine. 2005; 353(17): 1793-1801.

92. Jiang, Danjie, et al. "The diagnostic value of DNA methylation in leukemia: a systematic review and meta-analysis.PLOS. 2014; 9(5): 96822e: 1-7.

93. Qian, C.; Zhou, M-M. SET domain protein lysine methyltransferases: struture, specificity and catalysis. Cellular and molecular life sciences, 2006; 63(23): 27552763.

94. Zhang, X.; Wen, H.; SHI, X. lysine methylation: beyond histones. Acta biochimica et biophysica. 2012; 44(1):14-27.

95. Herz, Hans-Martin, Alexander Garruss, and Ali Shilatifard. "SET for life: biochemical activities and biological functions of SET domain-containing proteins." Trends in biochemical sciences. 2013; 38(12): 621-639.

96. Simpson, N.E et al. modifying metabolically sensitive histone marks by inhibiting glutamine metabolism affects gene expression and alters cancer cell phenotype. Epigenetics: official journal off the DNA methylation society, 2012; 7(12):1413-1420.

97. Lee, J.K. Kim, K.C.; DZNep, inhibitor of Adenosylhomocysteine hydrolase, down-regulates expression of SETD1B H3k9me3 HMTase in human lung cancer cells. Biochemical and biophysical research communications, 2013;438(4):647-652. 98. $\mathrm{Li}, \mathrm{Y}$. et al. the target of the NSD family of histone lysine methyltransferase depends on the nature of the substrate. The journal of biological chemicistry, 2009; 284(49):34283-34295.

99. LI, B.; CAREY, M.; WORKMAN, J. C. The role of chromatin during transcription. Cell. 2012; 128: 707-719. 
100. Ceol, C.J. et al. The histone methyltransferase SETD1B is recurrently amplified in melanoma and accelerates its onset. Nature. 2011; 471(7339):513-517. 101. Zhang K, Haversat JM, Mager J. CTR9/PAF1c regulatesmolecular lineage identity, histone $\mathrm{H} 3 \mathrm{~K} 36$ trimethylation and genomic imprinting during preimplantation development. Dev Biol. 2013;383:15-27.

102. Gossage, L. et al. Clinical and pathological impact of VHL, PBRM1, BAP1, SETD2, KDM6A and JARID1c inclear cell renal renal carcinoma. Genes, chromosomes and cancer, 2014; 53(1):38-51.

103. Newbold, R.F.; Mokbel, K. evidence for a tumor supressor function of SETD2 in human breast cancer: new hypothesis. Anticâncer research. 2010; 30(9):3309-3311. 104. Duns, E. et al. Histone Methyltransferase Gene SETD2 Is a Novel Tumor Suppressor Gene in Clear Cell Renal Cell Carcinoma. Cancer Research. 2010; (70): 4287-4291.

105. CHEN, $Z$ et al. The role of a newly identified SET domain-containig protein, SETD3 in oncogenesis. Haematologica. 2013; 98 (5): 739-743.

106. Kim, D.; Kim, K.; Kim, J.; Seo, S. Histone Methyltransferase Setd3 Regulates Muscle Differentiation. Bioscience, Biotechnology and Biochemistry. 2011; 75 (2), p. 289-294.

107. Arantes Faria, J.A. Q et al. SET domain containg protein 4 (SETD4) is a newly identified cytosolic and nuclear lysine methytransferase involved in breast cancer cell proliferation. J Cancer Sci Ther. 2013; 5: 058-065.

108. Muzny, D. M. et al. the DNA sequence, annotation and analysis of human chromosome 3. Nature, 2006; 440(7088): 1194-1198.

109. Binda, O. et al. SETD6 monomethylates H2AZ on lysine 7 and is required for the maintenance of embryone stem cell self-renewal. Epigenetics: official journal of the DNA methylation Society, 2013; 8(2):177-183.

110. Wang, $\mathrm{H}$. et al. Purification and functional characterization of a histone $\mathrm{H} 3$-lysine 4-specific methyltransferase. Molecular cell, 2001; 8(6):1207-1217.

111. Del Rizzo, P.A.; Trievel, R.C.Substrate and product specificities of SET domain methyltransferases. Epigenetics: official journal of the DNA methylation Society. 2011; 6(9): 1059-1067.

112. Subramanian $\mathrm{K}$. et al. regulation of estrogen alpha by the SETD7 lysine methyltransferase. Molecular Cell, 2008; 30(3):336-347. 
113. Huang, J. et al. Two distinct nuclear receptor interation domains in NSD1, a novel SET protein that exhibits characteristics of both corepressors and coativators. The EMBO journal, 1998; 17(12):3398-3412.

114. Kapoor-Vazirani, P.; Vertino,P.M. A dual role for the histone methyltransferase PR-SETD7-SETD8 and histone H4 Lysine 20 monomethyltransferase in the local regulation of RNA polymerase II pausing. Journal of Biological Chemistry, 2014;289 (11): 7425-7437.

115. Wu, S.; Rice, J.C. A new regulator of the cell cycle: The PR-SEThistone methyltransferase. Cell cycle (Georgetown, Tex.), 2011; 10(1):68-72.

116. Beck, B.D. et al. biochemical characterization of metnases endonuclease activity and its role in NHEJ repair. Biochemistry, 2011; 50(20): 4360-4370.

117. Williamson, Elizabeth A., et al. "The SET and transposase domain protein Metnase enhances chromosome decatenation: regulation by automethylation. Nucleic acids research. 2008; 36 (18): 5822-5831.

118. Wray, J. et al. Metanase mediates resistance to topoisomerase in acute leukemia cells. Blood. 2009; 114(9):1853-1858.

119. Jeyaratnam, Dinisha Cyril, et al. "Delineation of known and new transcript variants of the SETMAR (Metnase) gene and the expression profile in hematologic neoplasms." Experimental hematology. 2014; 46(18): 448-456.

120. Fnu, Sheema, et al. "Methylation of histone H3 lysine 36 enhances DNA repair by nonhomologous end-joining." Proceedings of the National Academy of Sciences. 2011; 108(2): 540-545.

121. L.G. Shaffer, M.L. Slovak, L.J. Campbell,International Standing Committee on Human Cytogenetic N, ISCN 2009: An International System for Human Cytogenetic Nomenclature, Karger, Basel; Unionville, CT, 2009.

122. Pffal $M$. et al. A new mathematical model for relative quantification in real-time RT-PCR.NucleicAcids Research. 2001; 29: e45

123. Dawson, Mark A., Tony Kouzarides, and Brian JP Huntly. "Targeting epigenetic readers in cancer." New England Journal of Medicine. 2012; 367(7): 647-657.

124. Micheli, F.; Migliore, L. epigenetics of colorectal cancer. Clinical genetics, 2012; 81(4): 312-318.

125. Choohg, M. K.; Tsafnat, G. genetic and epigenetic biomarkers of colorectal cancer. Clinical gastroenterology and hepatology, 2012, 10(1): 9-15. 
126. Salz, T. et al. SETD1A regulates WNT target genes and controls tumor growth of colorectal cancer cells. Cancer research, 2014; 74(3): 775-786.

127. Giles, R.H.; van ES, J.H.; Clevers, H. caught up in a WNT storm: WNT signaling in cancer. Biochimica et biophysica acta, 2003; 1653(1): 1-24.

128. Tusi, Betsabeh Khoramian, et al. "Setd1a regulates progenitor B-cell-toprecursor B-cell development through histone $\mathrm{H} 3$ lysine 4 trimethylation and Ig heavychain rearrangement." The FASEB Journal 29.4 (2015): 1505-1515.

129. Xiao, Sheng, et al. "FGFR1 is fused with a novel zinc-finger gene, ZNF198, in the $t(8 ; 13)$ leukaemia/lymphoma syndrome." Nature genetics. 1998; 18(1): 84-87.

130. Buck, M. et al. Alterations in chromatina accessibility and DNA methylation in clear cell renal carcinoma. Oncogene. 2013; 4 (56): 356-362.

131. Sato, Y. et al. integrated molecular analysis of clear cell renal cell carcinoma. Nature genetics 2013; 45(8): 860-867.

132. Plank, Jennifer L., and Ann Dean. "Enhancer function: mechanistic and genome-wide insights come together." Molecular cell. 2014; 55(1): 5-14.

133. O'Neill, Daniel J., et al. "SETD6 controls the expression of estrogen-responsive genes and proliferation of breast carcinoma cells." Epigenetics. 2014; 9(7): 942-950.

134. A.J. Levine, M. Oren. The first 30 years of p53: growing ever more complex. Nat. Rev. Cancer. 2009; 9:749-758

135. Huang, J. et al. G9a and G1p methylate lysine 373 in tumor supressor p53. The jornal of biology chemistry, 2010; 285(13): 9636-9641.

136. Wray J, Williamson EA, Royce M, Shaheen M, Beck BD, Lee SH, Nickoloff JA, Hromas R.Metnase mediates resistance to topoisomerase II inhibitors in breast cancer cells..PLoS One. 2009;4(4):e5323. doi: 10.1371/journal.pone.0005323.

137. Apostolou P, Toloudi M, Kourtidou E, Mimikakou G, et al Potential role for the Metnase transposase fusion gene in colon cancer through the regulation of key genes. PLoS One. 2014; 15(10):e109741. 